Copyright

by

Benjamin Shawn Linhoff

2008 


\title{
Geochemical Evolution of Uraniferous Soda Lakes in Eastern Mongolia
}

\author{
by
}

\section{Benjamin Shawn Linhoff, BS}

\author{
Thesis \\ Presented to the Faculty of the Graduate School of \\ The University of Texas at Austin \\ in Partial Fulfillment \\ of the Requirements \\ for the Degree of
}

Masters of Science in Geological Sciences

The University of Texas at Austin

December 2008 
Geochemical Evolution of Uraniferous Soda Lakes in Eastern Mongolia

Approved by

Supervising Committee:

Philip C. Bennett, Supervisor

Jay L. Banner

John M. Sharp 


\section{Dedication}

This work is dedicated to my friends and students in Mongolia.

Bi tand ajil khudulmuriin amjilt khusie, bas tand eruul enkh sain saikhanii bukhniig khusen erooe. 


\section{Acknowledgements}

Many people have contributed to this work. I would like to thank my advisor Phil Bennett whose guidance, support, knowledge and energy made this project both fun and possible. My committee members Jack Sharp and Jay Banner whose input greatly improved this thesis. Ochir Gerel, my advisor in Mongolia whose wisdom, support, and friendship will always be remembered. Tamir Puntsag, my friend and colleague in Mongolia who helped with field work and made our expedition a success. The lab groupespecially Megan Franks, Elspeth Steinhauer, Jeff Landrum, Sarah Davidson, Eleanor Pate and Christopher Omelon whose ideas, assistance and friendship helped with everything from laboratory work to coffee breaks which I could not have done without.

This work could not have happened without the financial and logistical support from the Fulbright Program, The Mongolian University of Science and Technology, and the Jackson School of Geosciences at The University of Texas at Austin.

Finally, I would like to thank my parents and siblings for their love and support through all my endeavors.

$10 / 31 / 2008$ 


\begin{abstract}
Geochemical Evolution of Uraniferous Soda Lakes in Eastern Mongolia
\end{abstract}

\author{
Benjamin Shawn Linhoff, MSGeoSci
}

The University of Texas at Austin, 2008

Supervisor: Philip C. Bennett

Extremely high concentrations of $U$ were discovered in hypersaline soda lakes in eastern Mongolia. The lakes are small, shallow $\left(<1 \mathrm{~km}^{2},<1 \mathrm{~m}\right)$, and terminal with variable salinity. The origin and fate of $U$ in these lakes was investigated using geochemical analyses and modeling, using samples collected from lakes and lake pore waters, wells and a stream. Samples were analyzed for $\mathrm{Sr}$ and $\mathrm{U}$ isotopes, cations, trace metals, anions, total inorganic carbon (TIC), and unstable field parameters.

A representative groundwater in the field area is dilute and alkaline, with $\mathrm{pH}=7.9$, $10 \mathrm{mmol} \mathrm{L}^{-1}$ of TIC and $5 \mathrm{mmol} \mathrm{L}^{-1} \mathrm{Cl}^{-}$. In contrast, a representative lake water is $\mathrm{pH} \sim 10$ with TIC and $\mathrm{Cl}^{-}$each more than $1000 \mathrm{mmol} \mathrm{L}^{-1}$. Uranium concentrations in lake waters range from 0.24 to more than $62.5 \mu \mathrm{mol} \mathrm{L}{ }^{-1}$, possibly making these lakes the highest vi 
naturally occurring $U$ concentrations ever reported in a natural water. Groundwater concentrations of $\mathrm{U}$ range from 0.03 and $0.43 \mu \mathrm{mol} \mathrm{L}^{-1}$.

The $\mathrm{U}$ is natural and derived from groundwater discharging to stable closed basin lakes. Waters are concentrated by evaporation and $\mathrm{U}(\mathrm{VI})$ is chelated by $\mathrm{CO}_{3}^{-2}$ to form the highly soluble $\mathrm{UO}_{2}\left(\mathrm{CO}_{3}\right)_{3}^{-4}$. Two sets of well waters with corresponding lake discharge waters were analyzed for $U$ isotopes. Unnatural concentrations of ${ }^{235} U$ were tested for, the presence of which would indicate fallout-derived U. The average of four samples was ${ }^{238} \mathrm{U} /{ }^{235} \mathrm{U}=136 \pm 2$ indicating that the $\mathrm{U}$ is naturally derived. $\delta^{234} \mathrm{U}$ between one well and its corresponding discharge lake had similar $\delta^{234} U$ values $\left(\delta^{234} U=837.6\right.$ 858.5). The other sample pair however, revealed significant differences between the well and its discharge lake $\left(\delta{ }^{234} \mathrm{U}=303.6-1530\right)$. This suggests nuclide recoil is significantly enriching one of the lakes with ${ }^{234} \mathrm{U}$ beyond secular equilibrium during alpha-decay of ${ }^{238} \mathrm{U}$ in lake sediments or along the groundwater flow path. Modeled evaporation of lakes demonstrates that a U-mineral phase is likely to precipitate during evaporation.

Strontium isotopes varied in groundwaters between ${ }^{87} \mathrm{Sr} /{ }^{86} \mathrm{Sr}=0.706192-0.709776$ and in lakes ${ }^{87} \mathrm{Sr} /{ }^{86} \mathrm{Sr}=0.708702-0.709432$. Cretaceous mafic rocks likely account for low ${ }^{87} \mathrm{Sr} /{ }^{86} \mathrm{Sr}$ values while Cretaceous alkaline rhyolites account for the high ${ }^{87} \mathrm{Sr} /{ }^{86} \mathrm{Sr}$ values. High concentrations of $\mathrm{U}, \mathrm{Na}, \mathrm{Cl}^{-}$, and $\mathrm{K}$ correlate to radiogenic $\mathrm{Sr}$ in lake waters indicating that $\mathrm{U}$ is sourced from local Cretaceous alkaline rhyolites. 


\section{TABLE OF CONTENTS}

\section{Contents}

$\begin{array}{lll}\text { TABLE OF CONTENTS } & \text { VIII }\end{array}$

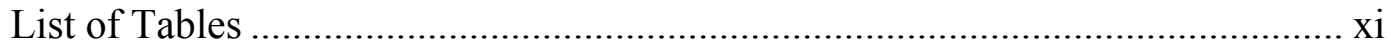

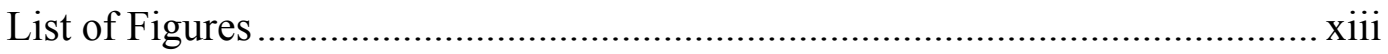

1 INTRODUCTION 1

1.1 Background .....................................................................................

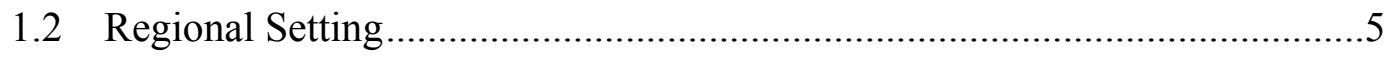

1.3 Uranium Geochemistry .............................................................

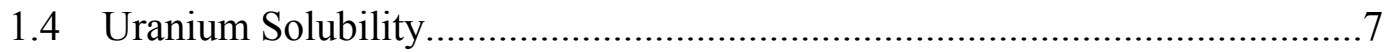

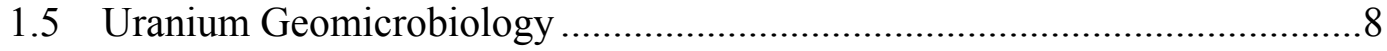

2 Materials ANd Methods $\quad 10$

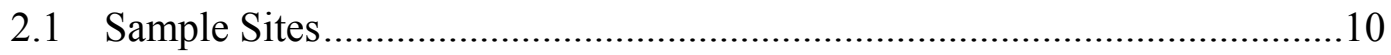

2.2 May Field Sampling .......................................................................... 11

2.3 August Field Sampling ...................................................................... 11

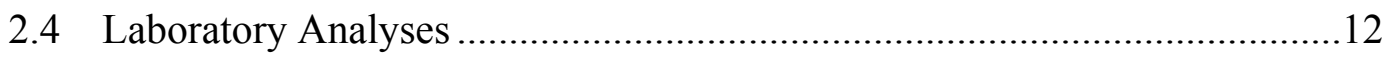

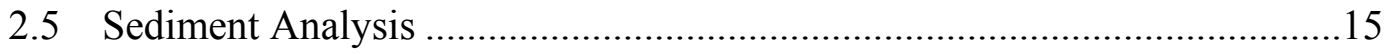

2.6 Chemical Modeling............................................................................ 16

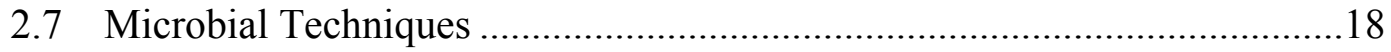

$\begin{array}{llr}3 & \text { RESUlTS } & \mathbf{2 0}\end{array}$

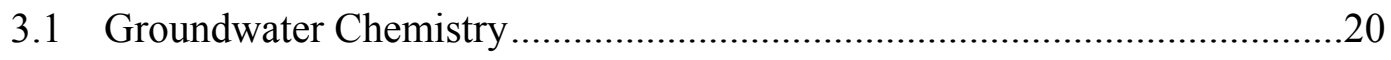

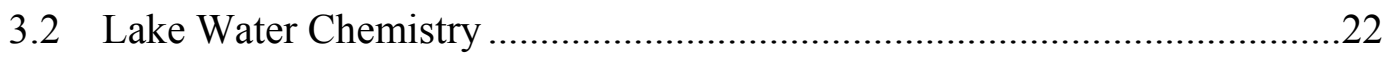




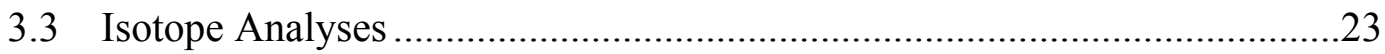

3.4 Sediment Analyses................................................................................24

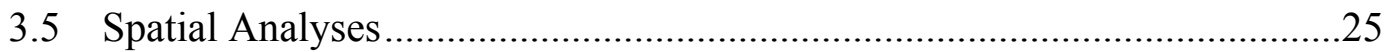

3.6 Chemical Modeling ..............................................................................26

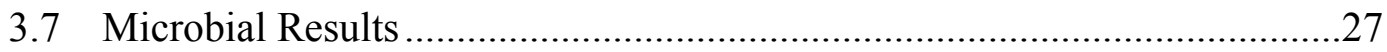

4 Discussion $\quad 28$

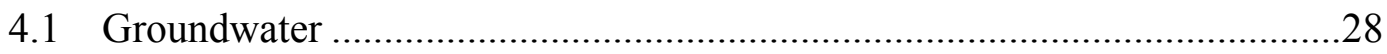

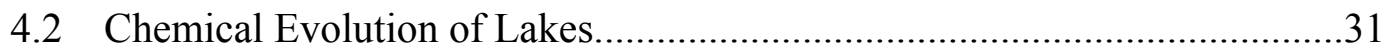

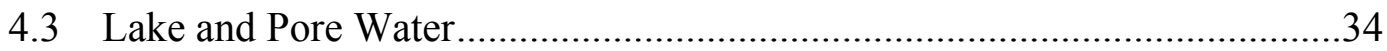

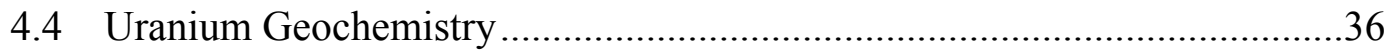

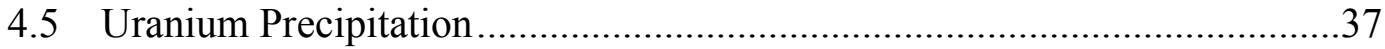

4.6 Source for Uranium in Soda Lakes and Groundwaters .................................39

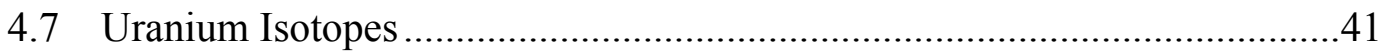

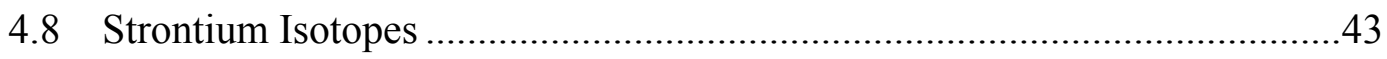

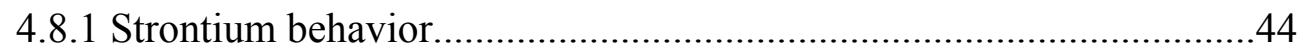

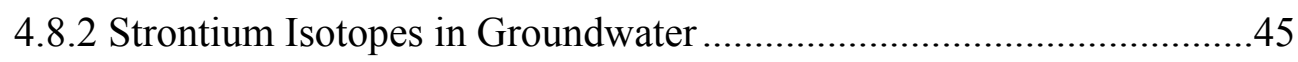

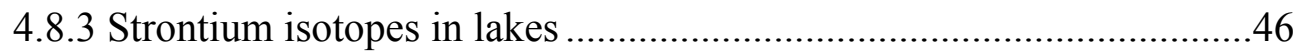




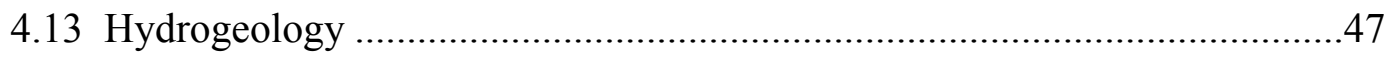

5 IMPLICATIONS $\quad 48$

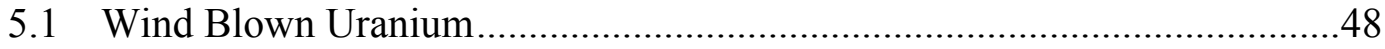

5.2 Health Effects of Uranium ............................................................................49

6 Conclusions 51

$\begin{array}{ll}\text { TABLES } & 53\end{array}$

$\begin{array}{ll}\text { FIGURES } & 76\end{array}$

$\begin{array}{ll}\text { APPENDIX A } & 107\end{array}$

$\begin{array}{ll}\text { APPENDIX B } & 112\end{array}$

$\begin{array}{ll}\text { REFERENCES } & 113\end{array}$

VITA 121 


\section{List of Tables}

Table 1: Equilibrium constants for $\mathrm{U}(\mathrm{VI})$-carbonate complexes from Guillaumont et al. (2003).

Table 2: Uranium minerals with associated stability constants and formulas. The stability constant for rutherfordine is from Guillaumont et al. (2003). Stability constants for carnotite and tyuyamunite are from Langmuir (1978)............................................. 53

Table 3: Latitude and longitude of all field sampling locations. .....................................5 54 Table 4: Strontium isotope analyses for groundwaters and lake waters with external and

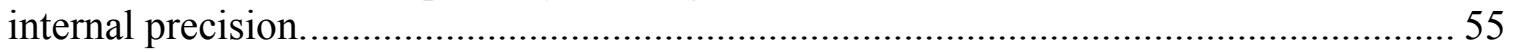

Table 5: Field Parameters for groundwater and lake water sampling sites.....................56 Table 6: Laboratory $\mathrm{pH}$, TIC, alkalinity and calculated $\mathrm{CO}_{2}, \mathrm{HCO}_{3}{ }^{-}, \mathrm{CO}_{3}{ }^{2-}$, and $\mathrm{NPOC}$ (non-purgable organic carbon) for groundwater and lake water samples.........................57

Table 7: Dissolved gases for groundwater and lake water samples............................... 58

Table 8: Anions for groundwater, lake water and pore water samples............................ 59

Table 9: Major cations for groundwaters, lake waters, and pore waters with results of charge balance calculations. Charge balance was not completed for pore waters because DIC was not measured and $\mathrm{HCO}_{3}{ }^{-}$is a major anion in these waters.

Table 10: May sampling of Kherlen River and Gurvany-1 Lake. Results include pH, major cations and anions.

Table 11: Trace metals for groundwater and total metal analyses of groundwater samples. $\mathrm{Fe}_{\mathrm{T}}$ and $\mathrm{As}_{\mathrm{T}}$ means total $\mathrm{Fe}$ and total $\mathrm{As}$.

Table 12: Continued trace metals for groundwater and total metal analyses of groundwater samples.

Table 13: pH profile of lake sediments in Tsaidam-1 Lake.............................................. 64

Table 14: Trace metals for lake water and lake pore water samples............................... 65

Table 15: Continued trace metals for lake water and lake pore water samples............... 66

Table 16: $\delta^{234} U$ and ${ }^{238} U /{ }^{235} U$ for Shar Burdiin Well and Lake and Tsaidam-2 Well 1 and Lake with measurement uncertainties. External precision for $\delta{ }^{234} U$ was calculated by Musgrove et al. (2001) for the instrument. Measurement uncertainty for ${ }^{238} \mathrm{U} /{ }^{235} \mathrm{U}$ is

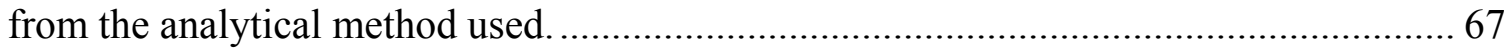

Table 17: Sediment analyses from XRD and ESEM analyses. ...................................... 67

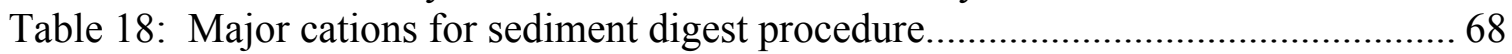

Table 19: Trace metals for sediment digest procedure.................................................... 69

Table 20: Continued trace metals for sediment digest procedure.................................... 70

Table 21: Saturation indices calculated using PHREEQC for select minerals in all

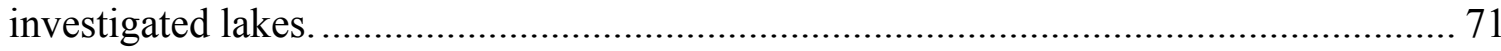

Table 22: Saturation indices for select minerals during the evaporation of Shar Burdiin Well

Table 23: Saturation indices of selected minerals during evaporation of Shar Burdiin Lake. 
Table 24: Correlation coefficient matrix for selected parameters for the 6 groundwater sample sites. Correlation coeffiecients were calculated using AquaChem. Values closer to one are more correlated, and negative values indicate a negative correlation.

Table 25: Correlation coefficient matrix for selected parameters for the five lake water sample sites. Correlation coeffiecients were calculated using AquaChem (version 3.7). Values closer to one are more correlated, and negative values indicate a negative correlation. 


\section{List of Figures}

Figure 1: Map of field site in eastern Mongolia.

Figure 2: Uranium speciation diagram using activities of $\left[\mathrm{UO}_{2}\left(\mathrm{CO}_{3}\right)_{3}{ }^{-4}\right]=10^{-15}$ and $\left[\mathrm{HCO}_{3}{ }^{-}\right]=10^{-0.419}$ calculated for Shar Burdiin Lake. The diagram shows log activities on the $\mathrm{y}$-axis and $\mathrm{pH}$ on the $\mathrm{x}$-axis. Diagram was created using Geochemist's Workbench ${ }^{\circledR}$.

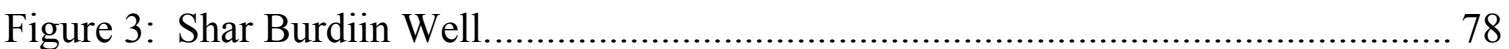

Figure 4: Field sampling at Tsiadam-1 Well. ........................................................... 79

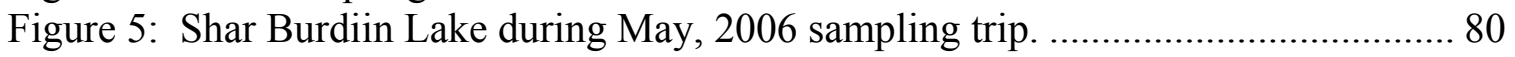

Figure 6: Shar Burdiin Lake during August,2006 sampling trip. ................................ 81

Figure 7: Stiff diagrams for each well and lake. Note that the scale for lakes is 0-3000

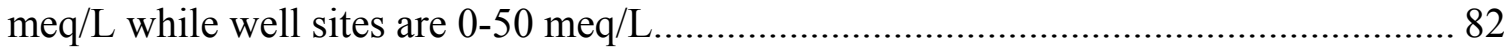

Figure 8: Catchment area for lakes shown in yellow with locations of groundwater and lake samples.

Figure 9: The investigated area is within in the black box. The approximate location of

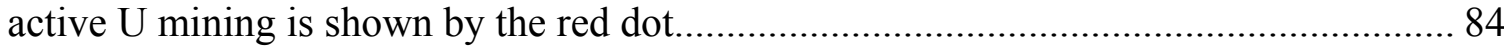

Figure 10: Choibalsan (spelled Choybalsan here) is located approximately $500 \mathrm{~km}$ east

of Ulaanbaatar.

Figure 11: Map of Mongolia. The location of the investigated area near Choibalsan is shown with the red star.

Figure 12: Uranium versus chloride for groundwater, lake water, and pore water samples.

Figure 13: Uranium concentrations versus total inorganic carbon for all well and lake samples and for the dissolved salt (per $\mathrm{kg}$ ) from the shore of Gurvany-2 Lake. 88 Figure 14: Uranium speciation with $\left[\mathrm{UO}_{2}\left(\mathrm{CO}_{3}\right)_{3}{ }^{-4}\right]=10^{-5},\left[\mathrm{HCO}_{3}{ }^{-}\right]=0.1$, $\left[(\mathrm{VO})_{2}(\mathrm{OH})_{5}\right]=10^{-5},\left[\mathrm{~K}^{+}\right]=10^{-2.6},\left[\mathrm{CaCO}_{3}\right]=10^{-5}$. The diagram shows log activity on the yaxis and $\mathrm{pH}$ on the $\mathrm{x}$-axis. Diagram was created using Geochemist's Workbench ${ }^{\circledR}$..... 89 Figure 15: Selected mineral SI values calculated in PHREEQC for Shar Burdiin Lake during evaporation.

Figure 16: Selected mineral SI values calculated in PHREEQC for Shar Burdiin Well

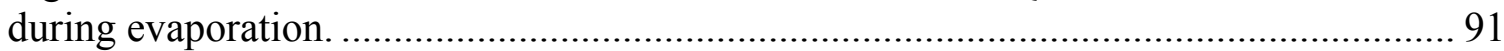

Figure 17: Chloride versus bromide for all wells, lakes and pore waters...................... 92

Figure 18: $\mathrm{Mg}+\mathrm{Ca}$ versus $\mathrm{HCO}_{3}+\mathrm{CO}_{3}$ for all well and lake samples.......................... 93

Figure 19: Calcium and magnesium derived from the sediment digestion procedure. ...99

Figure 20: $\mathrm{Mg} / \mathrm{Ca}$ versus $\mathrm{Mg}$ for wells, total metal, and lake water samples................. 95

Figure 21: Si versus $\mathrm{Cl}$ for wells, lakes, and pore water samples................................ 96

Figure 22: Modeled evaporation of water from Shar Burdiin Well using PHREEQC.

The y-axis shows log moles of the activity of the constituents while the $\mathrm{x}$-axis shows log

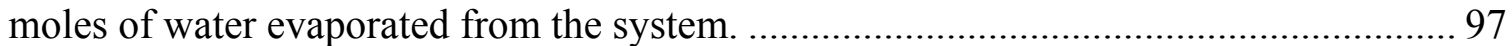

Figure 23: $\mathrm{Fe}_{\mathrm{T}}$ versus $\mathrm{Cl}$ for wells, lakes, and pore waters....................................... 98 
Figure 24: Iron speciation diagram created using Geochemist's Workbench ${ }^{\circledR}$. The diagram shows log activities on the $\mathrm{y}$-axis and $\mathrm{pH}$ on the $\mathrm{x}$-axis. [Fe] $=\log -11.75$, $\mathrm{T}=25^{\circ} \mathrm{C}, \mathrm{P}=1.013$ bars.

Figure 25: Sulfate speciation for conditions similar to Tsaidam-2 Lake. $\mathrm{T}=25^{\circ} \mathrm{C}$, $\mathrm{P}=1.013$ bars, $\left[\mathrm{SO}_{4}{ }^{-2}\right]=10^{-2.267},[\mathrm{Fe}++]=10^{-6.795}$. The diagram shows log activities on the $\mathrm{y}-$ axis and $\mathrm{pH}$ on the $\mathrm{x}$-axis. It was created using Geochemist's Workbench ${ }^{\circledR}$. 100 Figure 26: Sr versus $\mathrm{Cl}$ for all well, lake and pore water samples. The arrow shows the direction of increasing evaporation.

Figure 27: ${ }^{87} \mathrm{Sr} / 86 \mathrm{Sr}$ vs. $\mathrm{Cl}$ for groundwater and lake waters. ................................... 102

Figure 28: ${ }^{87} \mathrm{Sr} /{ }^{86} \mathrm{Sr}$ versus $\mathrm{Mg}+\mathrm{Ca}$ for wells and lake waters. ................................... 103

Figure 29: ${ }^{87} \mathrm{Sr} /{ }^{86} \mathrm{Sr}$ vs. $\delta^{234} \mathrm{U}$ for groundwater and lake water samples. ...................... 104

Figure 30: U/Ca vs. $\delta^{234} \mathrm{U}$ for groundwater and Tsaidam-2 Lake water........................ 105 Figure 31: May sampling of Gurvany-1 Lake and Kherlen River plotted with samples taken in August. 


\section{INTRODUCTION}

The extreme eastern region of Mongolia and the western fringe of neighboring China (aka Inner Mongolia) have many saline lakes of different compositions. The area is a closed basin continental interior that receives fresh stream flow from the Khentii Mountains of central Mongolia, and the intense summer evaporation results in the formation of saline lakes. These lakes vary in composition from $\mathrm{Na}-\mathrm{Cl}$ neutral $\mathrm{pH}$ brines, to $\mathrm{Na}-\mathrm{SO}_{4}-\mathrm{Cl}$ low $\mathrm{pH}$ brines, to $\mathrm{Na}-\mathrm{Cl}-\mathrm{HCO}_{3}$ high $\mathrm{pH}$ soda lakes (Egorov 1993; Williams 2006).

In eastern Mongolia, there are several saline lakes that are derived entirely from local groundwater discharge that evolve toward high $\mathrm{pH}$ soda lakes. Unlike similar soda lakes found in Nebraska (Gosselin et al. 1994) and other arid continental interior areas such as the Great Rift Valley (Beadle 1932), these lakes are located in a high latitude, extremely cold environment. The region is on the edge of the southern extent of the Siberian permafrost and on the northern edge of the Gobi Desert. Also different from most soda lakes, these lakes freeze solid in the winter, and there is significant loss of water due to direct sublimation of the ice (Zhang et al. 2005), which results in the wintertime precipitation of carbonate minerals.

These precipitated salts are mobilized by the local winds into massive dust storms that frequent central Asia in the spring. Wind blown sediments from these storms are known to travel hundreds to thousands of kilometer sometimes even circling the globe (Duce et al. 1983; Uematsu et al. 1983). A halophilic bacteria thought to originate in 
Mongolia was isolated from a salt crystal from non-saline soils in Japan (Echigo et al. 2005). While preliminary work has been done examining composition of Asian dust once it reaches the United States and elsewhere (Braaten and Cahill 1986; Husa et al. 2001), very little is known of the dust from its source in central Asia.

The unusual chemistry and evaporation mode of eastern Mongolia's soda lakes may result in unusual trace metal chemistry, especially with elements that form carbonate complexes. Abnormally high concentrations of $\mathrm{U}$ and other actinides are known to occur in Mono Lake California (Simpson et al. 1982), which is a large soda lake on the eastern slope of the Sierra Nevada Mountains. These high concentrations are attributed to fallout from above ground nuclear weapon testing in Nevada and New Mexico (Simpson et al. 1980). The high abundance of the ordinarily insoluble actinides in the soda lake is attributed to complexation with carbonates that dramatically increases solubility and inhibits chemical removal from the water column (Chang et al. 2001). Uranium concentrations from sediments from a desiccated soda lake in central Mongolia were recently found to have extremely high concentrations of $U\left(U=1500 \mu \mathrm{mol} \mathrm{kg}^{-1}, 350 \mathrm{ppm}\right.$ U) (Markwitz et al. 2008). Water from this lake has not been analyzed for $\mathrm{U}$ concentrations.

The Mongolian lakes represent an ideal location for studying the evolution of soda lakes at high latitude. There are several different lakes with different extents of evaporation, and the presence of numerous shallow wells within the small region allow for comparison of groundwater and surface water composition. During the initial stages of this investigation it was determined that some of the lakes had extremely high 
concentrations of dissolved $U$, possibly the highest ever reported in a natural water. The geochemistry of $U$ and how these lakes accumulate $U$ during their evolution is part of the focus of this study.

\subsection{Background}

Soda lakes contain high concentrations of $\mathrm{Na}$ and $\mathrm{CO}_{3}$ and have very high $\mathrm{pH}$. Generally, they are located in arid regions in terminal basins where evaporation causes the accumulation of salinity. Soda lakes typically form in siliceous terrain from the evaporation of water that is low in $\mathrm{Ca}$ and $\mathrm{Mg}$ concentrations (Eugster and Hardie 1978). The total salt content and carbonate concentrations vary depending on local conditions including evaporation rates, local geology, and the composition of the original evaporating water. A typical soda lake has a $\mathrm{Na}-\mathrm{HCO}_{3}-\mathrm{CO}_{3}-\mathrm{Cl}$ type water with $\mathrm{pH}=9$ 10.5 and TDS $>35,000 \mathrm{mg} \mathrm{L}^{-1}$ (Stumm and Morgan 1996).

During the evaporation of a $\mathrm{pH}$ neutral water, the alk/ $\mathrm{Ca}^{2+}$ ratio determines the initial trajectory for the evolution of the water. Waters in which $\mathrm{HCO}_{3}{ }^{-}$is approximately two times the $\mathrm{Ca}^{2+}$ concentration generally do not change their $\mathrm{Ca}^{2+}: \mathrm{HCO}_{3}{ }^{-}$ratio during evaporation and the $\mathrm{pH}$ remains neutral. When cations such as $\mathrm{Na}$ and $\mathrm{K}$ replace $\mathrm{Ca}$ such as during the weathering of silicate minerals then $\mathrm{HCO}_{3}^{-}>2 \mathrm{Ca}^{2+}$. When this water evaporates, $\mathrm{Ca}^{2+}$ is eliminated due to calcite precipitation and a soda lake will develop with high $\mathrm{pH}$ and $\mathrm{HCO}_{3}{ }^{-}$concentration. This is termed a geochemical divide (Eugster and Hardie 1978), and the resulting soda lake will be of the $\mathrm{Na}-\mathrm{CO}_{3}-\mathrm{SO}_{4}-\mathrm{Cl}$ type water as it evolves toward the next divide (Stumm and Morgan 1996). 
Soda lakes are often located in remote continental interiors. Examples include lakes in the East African Rift Valley (Drever 1997) where limnological studies including chemical, biological, and physical have been carried out for many years (Beadle 1932; Jenkin 1932; Rich 1932; Jones et al. 1977), and several lakes in the western United States. Probably the best studied soda lake in the United States is Mono Lake of California (Scholl and Taft 1964; Simpson et al. 1982; Johannesson and Lyons 1994; Sorokin et al. 2002).

Sorokin, $(2001,2002,2004)$ characterized the microbial communities in the eastern Mongolia soda lakes, and found both halophilic and halotoerant bacteria adapted to the broad range in salinities. Sorokin (2001) cultured alkaliphilic ammonia-oxidizing bacteria in $\mathrm{pH}$ values ranging from 9.7 to 10.5 . In a $\mathrm{pH}$-controlled, $\mathrm{NH}_{3}$ limited continuous culture, an isolate from the Mongolian soda lakes grew up to $\mathrm{pH}=11.3$, which is the highest $\mathrm{pH}$ limit known for ammonia-oxidizing bacteria (Sorokin et al. 2001). In lakes with salinities less than $60,000 \mathrm{mg} \mathrm{L}^{-1}$, the microbial communities include aerobic and anaerobic phototrophic, methanogenic, methanotrophic, sulfur-oxidizing, sulfatereducing and nitrifying bacteria. In hypersaline lakes (salinity $>100,000 \mathrm{mg} \mathrm{L}^{-1}$ ), the sulfur cycle remained active due to the activity of extremely halotolerant and alkaliphilic sulfur bacteria while ammonium oxidizers and methanogens were not detected (Sorokin et al. 2001; 2002; 2004).

Several studies recently published described the groundwater geochemistry, stable isotope geochemistry and atmospheric processes in eastern Mongolia near the town of Choibalsan (Yamanaka et al. 2005; Sugita et al. 2007; Tsurjimura et al. 2007). 
Yamanaka (2007) used a Rayleigh type model to reproduce daily variations in observations of $\delta \mathrm{D}$ and $\delta^{18} \mathrm{O}$ over eastern Mongolia and determined that observed isotopic variation of precipitation could be explained by rainout during transportation from a single vapor-source reservoir likely corresponding to a subtropical marine atmosphere in southern China. The Kherlen River (Figure 1) which runs adjacent to Choibalsan is a $\mathrm{Ca}-\mathrm{HCO}_{3}$ type water (Egorov 1993). Tsujimura (2007) determined that groundwaters in the headwaters of the Kherlen River were also $\mathrm{Ca}-\mathrm{HCO}_{3}$ type waters but that groundwaters near Choibalsan were variable and $\mathrm{Na}, \mathrm{Mg}, \mathrm{Cl}^{-}$and $\mathrm{HCO}_{3}^{-}$ concentrations were considerably higher than in the river water and upstream groundwater. Tsujimura (2007) concluded that near Choibalsan groundwater interaction with the Kherlen River is not a controlling mechanism for river water chemistry.

\subsection{Regional Setting}

Mongolia (Figure 11) is very sparsely populated with fewer than three million people with a total area of $1,564,116 \mathrm{sq} \mathrm{km}$. The climate is extreme with both hot summers and extremely cold winters with seasonal temperatures that range from $+40^{\circ} \mathrm{C}$ to $-40^{\circ} \mathrm{C}$. Much of the country is semi-arid to arid steppe. Saline lakes are widespread throughout the arid regions of Mongolia and are particularly abundant in the eastern region of the country (Egorov 1993). Many of these lakes are soda lakes.

The field site is north of the town of Choibalsan at approximately N 48.318275, E 114.506437 at an elevation of $\sim 760 \mathrm{~m}$ and encompasses an area that is approximately 50 
$\mathrm{km}^{2}$ (Figure 1). Choibalsan is located in northeastern Mongolia about $500 \mathrm{~km}$ east of the capital city, Ulaanbaatar (Figure 10).

Precipitation in the field area is sparse with an average of $207.6 \mathrm{~mm}$ a year (Choibalsan METAR). Almost $70 \%$ of rain falls between June and August and snowfall is scarce (Sugita et al. 2007). Much of the winter snowfall is lost through sublimation, the rates of which are highest in the spring when temperatures are still below freezing (Zhang et al. 2008). During 2006 field season, the weather station at Choibalsan airport recorded $162.8 \mathrm{~mm}$ of rain, of which 145.27 came before samples were taken in August (Choibalsan METAR). This amount of rainfall is slightly below average for the region.

Brown Pleistocene loess soils cover the investigated field area and are typically 10-30 m thick (Agnerian et al. 2007). These loess deposits are widespread throughout central Asia covering the semi-arid regions on the periphery of all the major deserts including the Gobi Desert of northern China and Mongolia (Figure 11) (Dodonov 1991). The mineral composition of these soils is typically quartz (75\%) and carbonates $(20 \%)$ and a small percentage other minerals of varied composition (Dodonov 1979).

Underlying the loess are Lower Cretaceous basalts, andesites, and alkaline rhyolites (Mironov 2006). Elevated concentrations of $U$ have been found in the rhyolites and associated volcanic breccias in the region, several of which are located within $20 \mathrm{~km}$ of the investigated area (Figure 1) (Mironov 2006).

Approximately $100 \mathrm{~km}$ to the north of the investigated area, there are several large $U$ deposits that have been mined intermittently since the 1970 s and recently have been reopened (Figure 9) (Agnerian et al. 2007). The U deposits occur as pitchblende- 
coffinite assemblages that are hosted by conglomerates and sandstones constrained above by Jurassic tuff and below by Jurassic andesite and basalt (Agnerian et al. 2007).

\subsection{Uranium Geochemistry}

Uranium is a relatively common element found in rocks, sediments and waters. A typical soil contains $\sim 60 \mu \mathrm{mol} \mathrm{kg}^{-1}$ (14 ppm U) while the average crustal rocks contains between 1-2 $\mu \mathrm{mol} \mathrm{kg}^{-1}$ (238-476 ppb U) (Turekian and Wedepohl 1961). As an example of a natural water, the ocean contains about $0.01 \mu \mathrm{mol} \mathrm{L}^{-1} \mathrm{U}(3 \mathrm{ppb} \mathrm{U})(\mathrm{Ku}$ 1977). Uranium is an incompatible element in magmas and becomes concentrated in highly fractionated and evolved granitic melts. This is especially the case in alkali granitic melts where $\mathrm{U}$ can become concentrated enough to form uraninite $\left(\mathrm{UO}_{2}\right)$ ore deposits (Friedrich and Cuney 1989).

\subsection{Uranium Solubility}

Uranium solubility, as with other actinides, is strongly affected by its ability to form complexes (Langmuir 1978). Complexation strength is a measure of how effectively a ligand can compete with water in the coordination sphere of an actinide ion. Actinide ions are "hard" acids and consequently form strong complexes with highly ionic "hard" ligands, such as carbonate and hydroxide (Katz et al. 1986). Figure 2 shows $\mathrm{U}(\mathrm{VI})$ species and solubility of $\mathrm{U}(\mathrm{VI})$-carbonate complexes as a function of $\mathrm{pH}$ demonstrates the increase in solubility of $\mathrm{U}$ with complexation by carbonate, and Table 1 shows the stability constants of the $\mathrm{U}(\mathrm{VI})$-carbonate complexes. Because of the 
formation of stable, soluble, $\mathrm{U}(\mathrm{VI})$-carbonate complexes (Langmuir 1978), $\mathrm{U}$ is thought to behave conservatively in oxygenated waters (Ku 1977).

The actinides are unique as metals in that they are soluble in their oxidized form, $\mathrm{U}(\mathrm{VI})$, and relatively insoluble when reduced $\mathrm{U}(\mathrm{IV})$. When $\mathrm{U}$ is reduced, it precipitates as microcrystalline uraninite $\left(\mathrm{UO}_{2}\right)$ or another $\mathrm{U}$ bearing mineral (Table 2) (Langmuir 1978).

\subsection{Uranium Geomicrobiology}

Jensen (1958) first suggested in 1958 that there is a biological role for the formation of uraninite. Since then, at least 25 microorganisms have been isolated that have the ability to reduce U(VI) enzymatically (Suzuki and Banfield 1999). Because all organisms isolated to date are $\mathrm{S}$ or Fe reducers, it is possible that there could be many more strains of bacteria capable of $\mathrm{U}(\mathrm{VI})$ reduction. The first organism recognized to use $\mathrm{U}(\mathrm{VI})$ as its terminal electron acceptor was Geobacter metallireducens (Lovley et al. 1991). Geobacter metallireducens grows under anaerobic conditions by coupling the oxidation of acetate with $\mathrm{CO}_{2}$ while simultaneously reducing $\mathrm{Fe}$ (III) to $\mathrm{Fe}$ (II) (Lovley et al. 1987). To date, only Shewanella putrefaciens and Geobacter metalliruducens have been shown to have the ability to grow using $\mathrm{U}(\mathrm{VI})$ as their sole electron acceptor (Lovley et al. 1991; Haas et al. 2001).

Numerous experiments have shown that a low redox potential is not enough to reduce $\mathrm{U}(\mathrm{VI})$ to $\mathrm{U}(\mathrm{IV})$ (Anderson and Lovley 2002) at Earth surface temperatures, and that a microbial process is required (Lovley et al. 1991; Lloyd and Macaski 2000). 
Thermodynamic calculations have indicated that, per electron transferred, acetate oxidation coupled with $\mathrm{U}(\mathrm{VI})$ reduction has the potential to yield twice the energy as Fe(III) reduction suggesting a favorable pathway for biological reduction of U(VI) (Cochran et al. 1986).

Despite the strong U(VI)-carbonate complex, U-reducing bacteria are effective in aenerobic conditions at reducing $\mathrm{U}(\mathrm{VI})$ when complexed with carbonate (Lovley et al. 1991). The bacteria G. metallireducens (Gorby and Lovley 1992) and D. desulfuricans have been shown to reduce $\mathrm{U}(\mathrm{VI})$ to $\mathrm{U}(\mathrm{IV})$ when $\mathrm{U}(\mathrm{VI})$ is complexed with carbonate (Lovley 1992). 


\section{MATERIALS AND METHODS}

Two field surveys were conducted in late May and late August of 2006 as part of a joint effort between The Mongolian University of Science and Technology and The University of Texas at Austin. During the May field survey, samples were collected from Gurvany-1 Lake and the Kherlen River. The August survey served as the main sampling expedition, and water samples were taken from a group of five lakes, including Gurvany1 Lake, eight wells and one stream (Figure 1).

The stream and all well samples, except for Background Well, are named for the lakes they are closest to. A digital elevation map and a slope layer created in ArcGIS were used to verify that wells named after lakes are located within the lake's catchment

area (Figure 8). The only exception was Tsiadam-1 Well which is not within the catchment area of Tsiadam-1 Lake. Gurvany Stream is entirely within the catchment area of Gurvany-1 Lake; it was sampled $100 \mathrm{~m}$ from its discharge point in Gurvany-1 Lake. Shar Burdiin Well is in the catchment area of both Shar Burdiin Lake and Gurvany-2 Lake and is treated as a representative groundwater for the catchment area of both lakes.

\subsection{Sample Sites}

Semi-nomadic herders have dug shallow wells (Figure 3) throughout the area for both human and livestock consumption. The wells are dug by hand and water is collected by bucket. They are typically $2 \mathrm{~m}$ in depth and approximately $1 \mathrm{~m}$ in diameter. Only one stream runs through the investigated area and discharges to Gurvany-1 Lake in the 
southern region of the field area. At least one well was sampled within the catchment area of every lake sampled in this study. Shar Burdiin Well is within the catchment area of both Shar Burdiin Lake and Gurvany-2 Lake and is treated as a representative groundwater for the catchment area of both lakes. The Kherlen River was sampled near the town of Choibalsan. Latitude and longitude of all field sites are listed on Table 3.

\subsection{May Field Sampling}

Unstable field parameters including temperature and $\mathrm{pH}$ were measured by electrode methods, and unfiltered water samples were collected in 1 L LDPE water bottles from Kherlen River and Gurvany-1 Lake. Sampling locations were recorded using a portable GPS receiver.

\subsection{August Field Sampling}

Unstable field parameters were measured immediately at each sampling location. Specific conductivity, $\mathrm{pH}$, ORP, and temperature were measured by electrode methods. Field alkalinity titrations using $0.1 \mathrm{~N} \mathrm{HCl}$ were conducted at the well sites (Figure 4) but were impractical to complete at the soda lakes due to the extremely high concentrations of carbonates. Sampling site locations were recorded using a portable GPS receiver.

Filtered $(0.2 \mu \mathrm{m})$ and unfiltered samples were collected in LDPE and glass bottles for laboratory analyses of major cations and anions as well as trace element concentration, DIC, laboratory alkalinity, and $\mathrm{Sr}$ and $\mathrm{U}$ isotope analyses. Dissolved oxygen was measured in the field by electrode methods and by colorimetry (CHEMetrics 
()). Samples for metals analysis, and $\mathrm{Sr}$ and $\mathrm{U}$ isotope analyses were preserved with reagent grade concentrated nitric acid to a $\mathrm{pH}<2$. This acid was used in procedural field banks. Samples were kept chilled until transferred to The University of Texas at Austin where they were stored at $4^{\circ} \mathrm{C}$.

Sediment samples were collected using sterile $60 \mathrm{~mL}$ syringe piston samplers and then stored in a portable electric cooler. These lake bottom sediments were taken at approximately the same location as lake water was collected and represent approximately the top fifteen centimeters of lake sediment. One salt crust sample was taken using a 60 $\mathrm{mL}$ syringe piston sampler at Gurvany-2 Lake, collected $\sim 2 \mathrm{~m}$ from the lake shore.

\subsection{Laboratory Analyses}

Water samples collected during the May field survey were analyzed at the Central Geological Laboratory in Ulaanbaatar, Mongolia. Major cations were determined using Atomic Absorption. Anions were determined through spectrophotometric methods. Alkalinity titrations were completed to calculate bicarbonate and carbonate concentrations.

All analyses of samples collected during the August field survey were performed at The University of Texas at Austin. Anions were determined in water samples by single column ion chromatography with a Millipore Waters 430 Conductivity Detector using conductivity and UV absorption detection (Millipore Water 486 Tunable Absorbance Detector). Major cations and trace metal concentrations were measured using an Agilent 7500ce quadrupole ICP-MS. Uranium concentrations were confirmed 
using a Finnigan-MAT 261 thermal ionization mass spectrometer. Total and inorganic carbon was analyzed using a Dohrman DC-180 carbon analyzer. Alkalinity was measured in the laboratory using an auto-titrator. Dissolved gases, $\mathrm{O}_{2}, \mathrm{~N}_{2}, \mathrm{Ar}, \mathrm{CH}_{4}$ and $\mathrm{CO}_{2}$ were measured by gas chromatography using a Hewlett Packard 5890A Gas Chromatograph.

Water density was determined by weighing a known volume of unfiltered and unpreserved sample from each lake and well. The scale was calibrated before it was used and ultrapure de-ionized water was used as a standard weight to reference samples. Each sample was weighed three times, and the averages of these measurements are reported here.

Total recoverable metals in unfiltered groundwater samples were analyzed using EPA method 3005A. In the field, samples collected for total recoverable metals were acidified using nitric acid. A procedure blank and field blank were used for control for this method. In the laboratory, a $30 \mathrm{~mL}$ sample was weighed and then acidified using 1 $\mathrm{mL}$ each of concentrated reagent grade $\mathrm{HCl}$ and $\mathrm{HNO}_{3}$. Samples were then heated to $95^{\circ} \mathrm{C} \pm 5^{\circ} \mathrm{C}$ without boiling for eight hours until the volume was reduced to $\sim 5 \mathrm{~mL}$. Samples were then diluted using nano pure water to $50 \mathrm{~mL}$, weighed and analyzed for major cations and trace metals using the Agilent 7500ce quadrupole ICP-MS.

Uranium isotopes were analyzed using a Finnigan-MAT 261 thermal ionization mass spectrometer following methods detailed in Musgrove et al (2001) on samples from Shar Burdiin Lake, Shar Burdiin Well, Tsaidam-2 Lake and Tsaidam-2 Well 1. Filtered water samples from these selected lakes and wells were acidified using concentrated 
$\mathrm{HNO}_{3}$, then spiked with ${ }^{233} \mathrm{U}-{ }^{236} \mathrm{U}\left({ }^{233} \mathrm{U} \cong{ }^{236} \mathrm{U}\right)$ tracers. $\mathrm{U}$ tracer solutions were calibrated using a gravimetric solution of New Brunswick Laboratories (NBL) Standard Reference Material 112-A. Musgrove et al. (2001) completed thirty-three measurements of NBL 112 -A over a three year study which yielded a mean $\delta^{234} \mathrm{U}$ value of $-37.0 \% 0 \pm 3.2 \%$ $($ error $=$ external $2 \sigma)$. Uranium was coprecipitated from the sample-tracer solutions with $\mathrm{Fe}(\mathrm{OH})_{3}$ and purified by ion-exchange chemistry. A two-column separation $(750 \mathrm{uL}$ and $160 \mathrm{uL}$ ) was performed using Bio-Rad anion exchange resin AG1 X8, 100-200 mesh. Yields are $\sim 90 \%$ for U. A total procedural blank (chemistry plus filament loading) was analyzed and was $3 \leq p g$ for $U$. This is insignificant for the amounts of $U$ measured. ${ }^{238} \mathrm{U} /{ }^{235} \mathrm{U}$ was measured during $\mathrm{U}$ isotope analysis to test for the presence of anthropogenic bomb-fallout $\mathrm{U}$. Complications associated with measuring ${ }^{238} \mathrm{U} /{ }^{235} \mathrm{U}$ include the difficulty in measuring the small abundance of ${ }^{235} \mathrm{U}$ relative to ${ }^{238} \mathrm{U}$, the small amount of ${ }^{235} \mathrm{U}$ in the spike, and the uncertainty in fractionation in the measurement. However, because weapons grade $U$ usually consists of $\sim 85 \%{ }^{235} U$ (Sublette 2001), these complications were insignificant in determining whether the majority of $U$ was natural or anthropogenic.

Strontium isotope analytical methods followed those of Banner and Kaufman (Banner et al. 1994). Strontium separation was achieved using $\mathrm{Sr}$ specific resin (Eichrom). Samples were first dried using approximately $2 \mathrm{~mL}$ of sample and $0.1 \mathrm{~mL}$ of $7 \mathrm{~N} \mathrm{HNO}_{3}$ in Teflon vials. Dried samples were dissolved in $3 \mathrm{~N} \mathrm{HNO}_{3}$ and $\mathrm{Sr}$ was isolated using the $\mathrm{Sr}$ specific resin (Eichrom). Analyses for $\mathrm{Sr}$ isotopes were completed using a Finnigan-MAT 261 thermal ionization mass spectrometer in dynamic multi- 
collection mode in the Department of Geological Sciences at the University of Texas at Austin. ${ }^{87} \mathrm{Sr} /{ }^{86} \mathrm{Sr}$ values are corrected for fractionation by normalizing the samples to ${ }^{86} \mathrm{Sr} /{ }^{88} \mathrm{Sr}=0.1194$, using an exponential fractionation law. External precision for strontium samples calculated over a three year period using this technique is \pm 0.0000017 $(2 \sigma, \mathrm{n}=422$, mean $=0.710266)$. The NIST-SRM-987 standard used in this study for two analyses had a mean of $0.710263 \pm 0.000008$ (Table 4). Strontium blanks determined for total collection procedure, including filtration in the field, were less than $300 \mathrm{pg} \mathrm{L}^{1-}$. This blank was negligible for the samples analyzed (sample/bank ratio=10-100). The blank determined for the ion exchange procedure was $20 \mathrm{pg}$. For this study, there were nine samples, one duplicate sample, and two standards (NIST-SRM-987) run.

\subsection{Sediment Analysis}

Sediments collected from all five lakes were analyzed for mineral and chemical composition. X-ray diffraction (XRD) was used to characterize the mineralogy of sediments collected from each lake. Oven-dried sediments were pulverized with a mortar and pestle and analyzed by powder x-ray diffraction methods using a Siemens D500 XRD with $\mathrm{Cu}$ K-alpha radiation $(\lambda=1.54 \mathrm{~A})$. Lake sediments were also examined using a Philips/FEI XL30 environmental scanning electron microscope (ESEM) to qualitatively characterize the chemical composition of the sediment. Pore water was extracted from all sediment samples by centrifugation. Because of the small quantity of water extracted from sediments, pore waters were only analyzed for major cations, anions, and dissolved metals. 
A partial digestion procedure was performed on lake sediment samples to determine environmentally available elements using EPA method 3050B. For each lake sediment sample, two grams of a representative sample were dissolved in a series of repeated additions of concentrated $\mathrm{HNO}_{3}$ and $30 \% \mathrm{H}_{2} \mathrm{O}_{2}$ (hydrogen peroxide). All chemicals used were reagent grade, and the analysis included a method blank and two duplicate samples for experimental quality assurance. A series of nitric acid additions were first added to the samples while samples were heated to $95^{\circ} \mathrm{C} \pm 5^{\circ} \mathrm{C}$ without boiling. Following the nitric acid additions, repeated additions of $30 \%$ hydrogen peroxide were added until effervescence was minimal. Samples were then heated without boiling for two hours and evaporated to approximately $5 \mathrm{~mL}$. Following evaporation, samples were diluted using nano pure water to $100 \mathrm{~mL}$. These solutions were then filtered using $0.2 \mu \mathrm{m}$ filters and analyzed for major cations and trace metals using the Agilent 7500ce quadrupole ICP-MS. Elements bound in silicate structures are not normally dissolved through this procedure. A duplicate sample was run for sediments from Tsaidam-2 Lake and Gurvany-2 Lake.

\subsection{Chemical Modeling}

PHREEQC (Parkhurst and Appelo 1999) was used to calculate speciation in water samples, calculate activities and model evaporation of groundwater and lake water. The program used the Pitzer equations to calculate ion activities in the lake waters and evaporation models to account for the high ionic strength of the solution. The MINTEQ (Allison et al. 1991) database in PHREEQC was used for well waters and for speciation 
and evaporation when $U$ was included. The saturation indices for a series of evaporite minerals and likely mineral phases, including the U-bearing minerals carnotite, tyuyamunite, and rutherfordine (Table 2), were calculated for all lake waters and for Shar Burdiin Well. In lakes where Ca was below the detection limit, $0.01 \mathrm{mmol} \mathrm{L}^{-1} \mathrm{Ca}$ was added to the model so as to estimate the saturation indices of Ca-bearing minerals. Shar Burdiin Well water was modeled at different stages of evaporation: $50 \%, 75 \%, 80 \%$, $90 \%$, and $99 \%$ loss of water. At each stage, the saturation indices of the selected minerals were recorded. By comparing $\mathrm{Cl}^{-}$concentrations between Shar Burdiin Well and Shar Burdiin Lake, it was possible to estimate the amount of evaporation between the well and its discharge lake. For Shar Burdiin Well to Shar Burdiin Lake, there was a $\sim 99.9 \%$ increase in $\mathrm{Cl}^{-}$, which was assumed to correlate to a $99.9 \%$ water loss between the well and the lake. However, the PHREEQC evaporation model failed at $99.9 \%$ evaporation so Shar Burdiin Well is only modeled to $99 \%$ evaporation.

The evaporation model was also used for Shar Burdiin Lake to predict the changing saturation indices for select minerals during evaporation. The lake was modeled for evaporation at $25 \%, 50 \%, 75 \%, 80 \%$, and $90 \%$ loss of water and the SI values for the selected mineral phases were recorded. In addition to this evaporation model, an inverse model was employed to evaluate changing ion concentrations and mineral precipitation during evaporation from Shar Burdiin Well. Predicted mineral phases were compared to the results of the XRD and ESEM sediment analyses to verify likely phases. 
Geochemist's Workbench ${ }^{\circledR}$ (version 7.0) was used to create speciation diagrams and model evaporation of lake and groundwater. Speciation diagrams were created for $\mathrm{Fe}, \mathrm{U}$, and $\mathrm{SO}_{4}{ }^{2-}$ using activities calculated with PHREEQC and representative temperature, pe, and $\mathrm{PCO}_{2}$ values.

AquaChem (version 7) was used to complete statistical analyses. Using this program, a matrix was created to show correlation coefficients of the chemical constituents in groundwaters and lake waters.

\subsection{Microbial Techniques}

A most probable number (MPN) technique was used to test for the presence of and approximate biomass of U-reducing bacteria. The method involved creating a media specific to Fe-reducing bacteria capable of $\mathrm{U}(\mathrm{VI})$ reduction. Sterile media was inoculated with an aliquot of lake sediment, diluted in series, and incubated for six weeks before observing whether any bacterial growth occurred. The method involves a serial dilution of the media to estimate the number of organisms in the sediment and relies on the theory of probability. There are several assumption made in an MPN. The first is that bacteria are distributed randomly throughout the sample. The second assumption is if a culture has organisms, it is certain to grow in the media. It should be noted that if the culture is poor, or more than one organism is required for growth, the MPN will give an underestimation of microbial density.

Several medias were created to simulate conditions in lake sediments that would be favorable for the growth of Geobacter, a known Fe and U reducer. Uranyl acetate was 
used as the electron acceptor and acetate was used for the electron donor for U-reducing bacteria. Medias specific to each lake varied only in concentrations of carbonate salts representative of measurements from TIC analyses. The media composition for Shar Burdiin Lake is included in Appendix B. The media was made anaerobic by boiling for two hours, sparging with Ar gas for fifteen minutes and then adding cysteine (a reducing agent) before being placed in an anaerobic glove box.

The first dilution in the MPN series was an inoculation of 1 gram of lake sediment into $10 \mathrm{mLs}$ of lake-specific media in a $20 \mathrm{~mL}$ serum bottle. Biomass was dislodged from the sediment by sonicating the inoculated media for five minutes. One $\mathrm{mL}$ of this media-solid-cell suspension was then extracted using a sterile syringe and injected into the next serum bottle in the series containing $9.0 \mathrm{~mL}$ of the same media, creating a 1:10 dilution. This procedure was repeated over an eight-fold dilution series and replicated four times. The procedure was repeated for each lake for a total of five MPN analyses.

The presence of U-reducing bacteria was determined by the formation or absence of a black $U$ precipitate. The precipitate was determined by a visual inspection of the vials after six weeks time. Sterile vials were used for each dilution series as the experimental control. 


\section{RESULTS}

\subsection{Groundwater Chemistry}

Results of groundwater field parameters are summarized on Table 5. Because of its similarity to well samples in water chemistry and its source in a spring, the single stream that was sampled is included in the groundwater results throughout the discussion. Other groundwater samples were taken from shallow wells between 1.7 to 4 meters depth. Water temperatures in well samples were much colder $\left(4.4-13.9^{\circ} \mathrm{C}\right)$ than the stream $\left(26.6^{\circ} \mathrm{C}\right)$. Groundwater $\mathrm{pH}$ was near neutral to slightly alkaline (7.09-7.97). The stream had a higher $\mathrm{pH}$ of 8.49 . Groundwaters were dilute with conductivities ranging between 1430 and $3192 \mu \mathrm{S}$. Oxygen content is between $0.07-0.22 \mathrm{mmol} \mathrm{L}^{-1}$ but in many cases was below the detection limit of the $\mathrm{O}_{2}$ probe. A CHEMetrics visual Vacu-Vial was used for two of the well samples and confirmed the very low oxygen content $(0.09$ $0.1 \mathrm{mmol} \mathrm{L}^{-1}$ ). Field alkalinities were performed on site on the Background Well and Tsaidam-2 Well 1 and were 6.44 and 10.8 meq alk $\mathrm{L}^{-1}$ respectively.

Results of TIC and laboratory alkalinity titrations for groundwaters and the stream water are summarized in Table 6. $\mathrm{CO}_{2}, \mathrm{HCO}_{3}{ }^{-}$, and $\mathrm{CO}_{3}{ }^{2-}$ were calculated from TIC for all samples. The calculated $\mathrm{CO}_{2}$ showed moderate agreement with $\mathrm{CO}_{2}$ measured using the gas chromatograph. Groundwater alkalinity ranged between 7.07 and $12.2 \mathrm{mmol}$ alk

$\mathrm{L}^{-1}$. pH measured in the lab was slightly higher than the field measurements. 
Dissolved gases for four groundwater samples, the stream, and Shar Burdiin Lake and Tsaidam-2 Lake are summarized on Table 7. Concentrations of dissolved oxygen measured on the gas chromatograph are generally lower than values measured in the field, with the exception of samples from the background well.

Major anions and cations are shown respectively on Table 8 and Table 9 for groundwater samples. These results show that the dominant anions are $\mathrm{Cl}^{-}, \mathrm{HCO}_{3}{ }^{-}$and $\mathrm{SO}_{4}{ }^{2-}$ while the dominant cation was $\mathrm{Na}^{+}$. The charge balance completed for these samples shows measured negative and positive ions are balanced within $\pm 3.7 \%$ for groundwater samples except for Tsaidam-1 Well. The reason for the discrepancy with this sample was not apparent. Major anions and cations for the May sampling of the Kherlen River are shown in Table 10. The dominant anions are $\mathrm{Cl}^{-}$and $\mathrm{HCO}_{3}{ }^{-}$while dominant cations are $\mathrm{Na}^{+}$and $\mathrm{Ca}^{2+}$.

Results of trace metal analyses for groundwaters are shown in Table 11 and Table 12. Uranium concentrations were varied between 0.03 and $0.43 \mu \mathrm{mol} \mathrm{L} \mathrm{L}^{-1}$. A wide range in trace metal concentrations was found in groundwater samples. Total Fe concentrations ranged between 0.13-12.6 $\mu \mathrm{mol} \mathrm{L}^{-1}$, Mn was between 0.24-4.58 $\mu \mathrm{mol} \mathrm{L}^{-1}$, $\mathrm{P}$ was between 23.7-79.3 $\mu \mathrm{mol} \mathrm{L}-1$, and $\mathrm{V}$ was between $0.02-1.72 \mu \mathrm{mol} \mathrm{L}^{-1}$.

Results from the total recoverable metal analyses are summarized in Table 11 and Table 12. $\mathrm{Al}, \mathrm{Mn}, \mathrm{Fe}_{\mathrm{T}}, \mathrm{Mg}, \mathrm{Pb}, \mathrm{As}, \mathrm{V}$, and $\mathrm{U}$ increased between the dissolved metals and total recoverable metals samples. A slight increase was observed in $\mathrm{U}$ concentrations between dissolved groundwater samples and total recoverable metal samples. 


\subsection{Lake Water Chemistry}

Results from the May sampling expedition are summarized on Table 10. These include major cations, anions, $\mathrm{pH}$ and temperature. Gurvany-1 Lake was approximately half the size in May what it was in August and Na concentrations are much higher in May than August measurements. Shar Burdiin Lake was completely dry during May whereas in August it had water (Figure 5 and Figure 6).

Field parameters measured in the lakes are summarized on Table 5. In the lakes temperature varied between $23.5-28.3^{\circ} \mathrm{C}, \mathrm{pH}$ was between 9.07-9.90, and the lakes were saline to very saline as conductivity ranged between $28.7-229.91 \mathrm{mS}$. A depth profile of $\mathrm{pH}$ in lake sediments was taken using a long $\mathrm{pH}$ probe. The $\mathrm{pH}$ increased from 9.3 to 10.3 from 0 to $20 \mathrm{~cm}$ depth (Table 13) in Tsiadam-1 Lake. Oxygen levels were measured in lake Gurvany-1 Lake and Tsaidam-1 Lake and were 0.27 and $0.35 \mathrm{mmol} \mathrm{L}^{-1}$ respectively. TIC, alkalinity and $\mathrm{pH}$ measurements made in the laboratory are shown on Table 6. TIC ranges between 24.7 to $1100 \mathrm{mmol} \mathrm{L}^{-1}$. Bicarbonate and carbonate were calculated from TIC measurements. Alkalinity measurements were between 25.9 and 1300 meq alk L ${ }^{-1}$. Tsaidam-1 Lake was the most dilute lake while Shar Burdiin and neighboring Gurvany-2 Lake were the most saline and alkaline.

Major anions and cations measured for lake water and extracted pore water samples are shown in Table 8 for anions and Table 9 for cations. Stiff diagrams for all lake and well waters are shown in Figure 7. These results show that like the groundwaters, the dominant anions are $\mathrm{Cl}^{-}, \mathrm{HCO}_{3}{ }^{-}$and $\mathrm{SO}_{4}{ }^{2-}$ while the dominant cation 
was $\mathrm{Na}^{+}$. In most of the lake waters, $\mathrm{SO}_{4}{ }^{2-}$ increased in the pore waters relative to the corresponding lake water samples. The sediment cores smelled strongly of rotten eggs indicating the presence of $\mathrm{H}_{2} \mathrm{~S}$. Charge balance calculations were completed for lake water samples and are $\pm 7.5 \%$. Charge balance was not completed for the lake pore water samples as DIC could not be measured on the very small amount of water extracted from the sediment.

Table 14 and Table 15 show trace metals in the lake waters and their corresponding pore waters. Like the groundwater samples, there was a large variation in $\mathrm{U}$ concentrations found in the lakes. Tsaidam-1 Lake had the lowest $\mathrm{U}$ concentrations with $0.24 \mu \mathrm{mol} \mathrm{L}{ }^{-1} \mathrm{U}$ while Shar Burdiin Lake had the highest $\mathrm{U}$ concentrations with $62.5 \mu \mathrm{mol} \mathrm{L}{ }^{-1} \mathrm{U}$. This wide range of concentrations was found in many of the trace metals in all of the lakes. In contrast, pore waters showed less variation in trace metal concentrations, and $\mathrm{U}$ varied from 0.99 to $23.8 \mu \mathrm{mol} \mathrm{L}^{-1} \mathrm{U}$ in the pore waters. Figure 12 shows that lakes with lower $U$ concentration in the surface water have higher concentrations in the pore water; lakes with extremely high concentrations of $U$ in surface water have a lower concentration of $U$ in the pore waters.

\subsection{Isotope Analyses}

Strontium isotopes showed large variation through the field site (Table 4). Strontium isotopes in well waters varied between 0.706120 and 0.709776 . Variation was not as pronounced in lake waters; ${ }^{87} \mathrm{Sr} /{ }^{86} \mathrm{Sr}$ was between 0.708847 in Tsaidam-2 Lake and 
0.709432 in Shar Burdiin Lake. There was a general geographic variation in the data with samples taken in the northern portion of the field being less radiogenic.

Uranium isotopes were measured in two lake catchment systems. Shar Burdiin Lake had a $\delta^{234} \mathrm{U}=858.5$ while Shar Burdiin Well had $\delta^{234} \mathrm{U}=837.6$. The difference in $\delta^{234} \mathrm{U}$ values for Shar Burdiin Lake and Shar Burdiin Well are significant relative to analytical uncertainty. Tsaidam-2 Lake and Tsaidam-2 Well 1 showed much greater variability with Tsaidam-2 Lake with $\delta^{234} \mathrm{U}=1530$ and Tsaidam-2 Well 1 had $\delta^{234} \mathrm{U}=303.6 .{ }^{238} \mathrm{U} /{ }^{235} \mathrm{U}$ is between $136 \pm 2$ which is within the analytical uncertainty of natural ${ }^{238} \mathrm{U}{ }^{235} \mathrm{U}=137.88$ (Jaffey et al. 1971). These results are summarized on Table 16.

\subsection{Sediment Analyses}

The results of the sediment analysis by XRD (Table 17) show that the lake bottoms are predominately composed of silicate and carbonate minerals. Silicates include quartz, albite, orthoclase, montmorilinite, phlogopite, and muscovite. Carbonates are found in all lakes except for Shar Burdiin and included calcite and dolomite. Anhydrite is present in Gurvany-1 Lake. Dolomite is only found in Tsaidam-1 and Tsiadam-2 Lakes. Overall there was little difference in the mineralogy between each lake. Results of each XRD analyses are included the Appendix A.

ESEM analyses of lake sediments confirms the presence of $\mathrm{C}, \mathrm{Na}, \mathrm{Mg}, \mathrm{Al}, \mathrm{Si}$, and trace element concentrations of $\mathrm{S}, \mathrm{Cl}, \mathrm{K}, \mathrm{Ca}$, and $\mathrm{Fe}$. One sediment grain from Gurvany1 Lake contained Zn. Table 17 shows the elements found through ESEM. 
Results from ESEM analysis of salt crystals collected from the shore of Gurvany2 Lake are predominantly composed $\mathrm{Na}, \mathrm{Cl}, \mathrm{C}$, and $\mathrm{S}$. The largest salt crystals are composed of $\mathrm{NaCl}$ and $\mathrm{NaC}$, suggesting that the crystals are halite and trona. TIC analysis of the dissolved salt crystal show high concentrations of inorganic carbon $\left(\mathrm{TIC}=349 \mathrm{mmol} \mathrm{kg}{ }^{-1}\right)$. Results of $\mathrm{U}$ analysis showed the salt contained $161 \mu \mathrm{mol} \mathrm{kg} \mathrm{kg}^{-1}$. Figure 13 shows $U$ versus TIC for the salt crystal and indicates that $U$ may be precipitated as rutherfordine (Table 2).

Results from the sediment digestion procedure are summarized in Table 18, 19, 20. High concentrations of $\mathrm{Al}, \mathrm{Fe}, \mathrm{Mn}, \mathrm{K}, \mathrm{V}$, and $\mathrm{Sr}$ were also found. Uranium found in the sediment digestion procedure is between 9.04-42.2 $\mathrm{mmol} \mathrm{kg}^{-1}$.

\subsection{Spatial Analyses}

Lakes and wells are grouped according to drainage basins determined using a digital elevation map in ArcGIS (Figure 8). Five basins are defined that encompass all sample sites. The Tsaidam-2 group is the southern most basins and includes Tsaidam-2 Lake, Tsaidam-2 Well 1 and Tsaidam-2 Well 2. North of this basin is the Gurvany group which includes Gurvany-1 Lake and Gurvany stream which drains into Gurvany-1 Lake. In the middle of the field site at the highest elevation is the Shar Burdiin group which includes Shar Burdiin Lake, Gurvany-2 Lake, and Shar Burdiin Well which is located just south of the two adjacent lakes. Gurvany-2 Lake is directly adjacent of Shar Burdiin Lake. The two lakes likely connect through a shallow channel during wet climate periods or rare heavy rainfall events. The Shar Burdiin group is the smallest basin of the group. 
To the northeast of Shar Burdiin is the Tsaidam-1 group that includes Tsaidam-1 Lake and Tsaidam-1 Well. Upon close examination of the ArcGIS slope layer, Tsaidam-1 Well likely represents groundwater flowing to the northeast to a basin that was not sampled.

\subsection{Chemical Modeling}

Speciation of waters in wells and lakes through PHREEQC determined that the vast majority of $\mathrm{U}$ in all lake and groundwater is complexed as $\mathrm{UO}_{2}\left(\mathrm{CO}_{3}\right)_{3}{ }^{-4}$. This is consistent with the U speciation diagram created using Geochemist's Workbench ${ }^{\circledR}$ that shows that $\mathrm{U}$ in waters with a $\mathrm{pH}>6.3$ is complexed as $\mathrm{UO}_{2}\left(\mathrm{CO}_{3}\right)_{3}{ }^{-4}$. When $\mathrm{V}$ is added to the model, the range of soluble $U$ decreases as carnotite (Table 2) becomes a viable mineral phase in reducing conditions. Figure 14 shows the speciation diagram for Shar Burdiin Lake created with Geochemist's Workbench ${ }^{\circledR}$ using activities of U, V, Ca, and $\mathrm{HCO}_{3}{ }^{-}$calculated in PHREEQC.

The saturation indices calculated in PHREEQC for a group of minerals in lake waters is shown on Table 21. Lakes are supersaturated with dolomite, calcite, strontianite, magnesite, and a number of iron phases including ferrihydrite, goethite, and hematite.

Saturation indices for a group of minerals during evaporation of Shar Burdiin Well are shown on Table 22. These values are plotted on Figure 15. Shar Burdiin Well before modeled evaporation is supersaturated with respect to calcite, dolomite, hematite, ferrihydrite, goethite and montmorillonite. Magnesite becomes supersaturated at 50\% 
evaporation and is followed by rhodocrosite $\left(\mathrm{MnCO}_{3}\right)$ at $75 \%$ evaporation. Strontianite $\left(\mathrm{SrCO}_{3}\right)$ becomes supersaturated at $80 \%$ evaporation. At $93 \%$ evaporation, sepiolite $\left(\mathrm{Mg}_{4} \mathrm{Si}_{6} \mathrm{O}_{15}(\mathrm{OH})_{2} \cdot 6 \mathrm{H}_{2} \mathrm{O}\right)$ becomes supersaturated. Finally, gypsum, followed by anhydrite become supersaturated at $\sim 95 \%$ evaporation.

During the modeled evaporation of Shar Burdiin Lake (Figure 16), several U minerals become supersaturated (Table 23). Carnotite (Table 2) is supersaturated at $20 \%$ evaporation of the lake which is followed by the supersaturation of the related mineral tyunyamunite (Table 2) at $45 \%$ evaporation. At $75 \%$ evaporation, at roughly the same time halite is supersaturated, rutherfordine (Table 2) becomes supersaturated. It should be noted that the timing of the supersaturation of tyunyamunite is only an estimation because the lake was given an artificial $\mathrm{Ca}$ concentrations to run the evaporation model. However, in Tsaidam-2 Lake which has $0.33 \mathrm{mmol} \mathrm{L}^{-1} \mathrm{Ca}, 3.89 \mu \mathrm{mol} \mathrm{L}^{-1} \mathrm{~V}$ and 0.59

$\mu$ mol $\mathrm{L}^{-1} \mathrm{U}$, carnotite became supersaturated at $80 \%$ while tyunyamunite became supersaturated at $82 \%$. A pe of 1 was used for the evaporation model and changing this value \pm 5 did not significantly alter the saturation index for any of the $U$ minerals described here.

\subsection{Microbial Results}

The results of the MPN show no signs of bacterial growth and no U-precipitate. A visual inspection of the media revealed no sign of a black U-precipitate. A light microscope was also used to look for bacteria and $\mathrm{U}$ precipitate but no evidence of either was observed. 


\section{DISCUSSION}

The chemical evolution of the soda lakes and an analysis of the extremely high concentrations of $U$ in lake waters is the focus of the discussion. The chemistry of groundwaters, lake waters, and lake pore waters is discussed and related to the chemical evolution of the lakes. The modeled chemical evolution of lake water and groundwater is used to predict the changing saturation indices of a group of mineral phases. Uranium geochemistry and the potential for the precipitation of $U$ mineral phases are examined through comparison of lake water and lake pore water chemistry, and through chemical modeling of the evaporation of Shar Burdiin Lake. Potential sources for U are discussed with respect to results from ${ }^{235} \mathrm{U} /{ }^{238}$ isotope analyses. Results from $\delta^{234} \mathrm{U}$ of the two lakes and two wells analyzed for $U$ isotopes show $\delta^{234} U$ increases along a flow path likely as a result of nuclide recoil. Strontium isotopes are used to demonstrate increasing water rock interactions as the lakes evolve towards increasing alkalinity. The wide range of ${ }^{87} \mathrm{Sr} /{ }^{86} \mathrm{Sr}$ values in groundwaters shows they are likely influenced by separate rock units. It is hypothesized that water rock interactions with the local Cretaceous alkaline rhyolites account for high ${ }^{87} \mathrm{Sr} /{ }^{86} \mathrm{Sr}$ in lake waters.

\subsection{Groundwater}

Figure 17, shows that $\mathrm{Cl}^{-}$directly correlates to $\mathrm{Br}^{-}$implying that evaporation of near surface groundwater is a controlling factor for these ion concentrations in 
groundwater samples. Other contituents, such as $\mathrm{Na}, \mathrm{SO}_{4}{ }^{2-}, \mathrm{K}, \mathrm{Fe}_{\mathrm{T}}, \mathrm{Mn}$, also behave conservatively and are generally higher when $\mathrm{Cl}^{-}$and $\mathrm{Br}^{-}$are higher.

Uranium in groundwaters varies considerably throughout the field area. Unlike lake waters, $\mathrm{U}$ in groundwaters does not correlate with conductivity or $\mathrm{Cl}^{-}$. This suggests that $\mathrm{U}$ concentrations cannot be simply explained by conservative behavior. One hypothesis is that elevated concentrations of $U$ in the local rocks is not ubiquitous but is perhaps constrained to a small region, probably near Shar Burdiin Lake and Gurvany-2 Lake where U concentrations were the highest. Interestingly, Shar Burdiin Well, Gurvany 2 Stream, and Tsaidam-1 Well, which have the highest U, also have the highest $\mathrm{pH}$.

Other elements with unusually high concentrations in groundwaters in this study that do not behave conservatively in groundwaters in general include: As, V, Co, and Se. These elements decrease in concentration with higher concentrations of $\mathrm{Cl}^{-}$. Like $\mathrm{U}$, higher concentrations of these elements also correlate to higher $\mathrm{pH}$. Generally, the waters with higher concentrations of As, V, Co, Se, and U- Shar Burdiin Well and Tsaidam-1 Well, are located in the central region of the investigated area (Figure 1). Higher $\mathrm{pH}$ and elevated concentrations of $\mathrm{U}, \mathrm{As}, \mathrm{V}, \mathrm{Co}$, and Se suggest local alkaline rhyolites are imparting incompatible elements to the water.

The results from the total recoverable metal analyses demonstrate that many constituents are sorbed to colloidal particles in the water column. High concentrations of $\mathrm{Ca}$ and $\mathrm{Mg}$ relative to dissolved metal samples indicate that dolomite and calcite are 
present as colloidal particles. This is consistent with PHREEQC speciation modeling showing that Shar Burdiin Well is supersaturated with respect to dolomite and calcite. Other mineral phases predicted in PHREEQC to be supersaturated in well waters include, montmorillonite, ferrihydrite, hematite, and goethite (Table 22). The high concentrations of $\mathrm{Al}, \mathrm{Na}, \mathrm{Fe}, \mathrm{Mg}$ and $\mathrm{Fe}_{\mathrm{T}}$ from the total recoverable metal analyses confirm that these minerals are likely present as colloidal particles in groundwaters.

Sorption onto Fe minerals is important for many heavy metals including $\mathrm{Pb}, \mathrm{V}$, and U. Peacock (2004) showed that V adsorption onto goethite readily happens at atmospheric conditions. PHREEQC modeling of groundwaters indicated that goethite is supersaturated in the investigated groundwater samples and V increased with respect to dissolved samples in the total recoverable metals analyses. Lead was high in the total metal analyses suggesting sorption onto ferrihydrite (Trivedi et al. 2003). Fox and Davis (2006) showed that in the presence of $1.8 \mathrm{mmol} \mathrm{L}^{-1} \mathrm{Ca}, \mathrm{U}(\mathrm{VI})$ can easily sorb onto ferrihydrite. However, in the absence of $\mathrm{Ca}, \mathrm{U}(\mathrm{VI})$ sorption onto ferrihydrite decreased 83\% (Davis et al. 2006). Groundwater samples had between $0.49-2.43 \mathrm{mmol} \mathrm{L}^{-1} \mathrm{Ca}$ implying that sorption onto ferrihydrite may be important in groundwaters. This may also account for the slight increase in $U$ concentrations between the total metal analyses and the dissolved metal analyses. In the soda lakes where $\mathrm{Ca}$ is absent, $\mathrm{U}(\mathrm{VI})$ sorption likely becomes less important. 


\subsection{Chemical Evolution of Lakes}

The chemical evolution of inland brines is determined by the chemistry of the dilute water from which the brine is derived (Hardie and Eugster, 1970). Soda lakes result from the evaporation of a water where $\mathrm{Ca}$ and $\mathrm{Mg}$ concentrations are less than half the alkalinity. When this type of water is evaporated, calcite is precipitated until essentially all available $\mathrm{Ca}$ is taken out of solution. As evaporation continues, $\mathrm{HCO}_{3}^{-}$ increases, raising the $\mathrm{pH}$ with no solubility boundary. This geochemical divide is the first of two chemical divides described by Hardie and Eugster (1970) for soda lakes. Subjected to further evaporation, the next geochemical divide happens when sepiolite or magnesium-rich smectite precipitates or dolomitization of calcite occurs. Jones and Van Denburgh (1966) demonstrated that dolomitization or magnesium-rich smectite precipitation are more likely than sepiolite formation in most natural waters (Jones and Van Denburgh 1966). Sepiolite formation and dolomitization occur according Equations 1 and 2:

$$
\begin{aligned}
& 3 \mathrm{Mg}^{2+}+4 \mathrm{Si}(\mathrm{OH})_{4}{ }^{\circ} \leftrightarrow \mathrm{Mg}_{2} \mathrm{Si}_{3} \mathrm{O}_{7.5}(\mathrm{OH})_{8} 2 \mathrm{H}_{2} \mathrm{O}+6 \mathrm{H}^{+}+3 \mathrm{H}_{2} \mathrm{O} \\
& \log \mathrm{K}=0.06 \\
& \mathrm{Mg}^{2+}+2 \mathrm{HCO}_{3}^{-}+\mathrm{CaCO}_{3} \leftrightarrow \mathrm{CaMg}^{-}\left(\mathrm{CO}_{3}\right)_{2}+\mathrm{CO}_{2}+\mathrm{H}_{2} \mathrm{O}
\end{aligned}
$$


Figure 17, which shows $\mathrm{Cl}^{-}$versus $\mathrm{Br}^{-}$, demonstrates that groundwater and lake water follow the same evaporation line, and that each lake has undergone different amounts of evaporation. This supports the hypothesis that discharging groundwaters are the predominant source of water for the soda lakes.

The lakes of the present study are derived from groundwaters that are deficient in Ca relative to $\mathrm{HCO}_{3}^{-}$. Figure 18, showing $\mathrm{Mg}+\mathrm{Ca}$ vs. $\mathrm{HCO}_{3}{ }^{-}+\mathrm{CO}_{3}{ }^{2-}$, demonstrates the loss of $\mathrm{Mg}$ and $\mathrm{Ca}$ with the formation of $\mathrm{HCO}_{3}^{-}$. When this water evaporates $\mathrm{Ca}$ is lost through the precipitation of calcite (Figure 15); a drop in $\mathrm{Ca}$ is seen between groundwater samples and corresponding lake waters; however, in three of the lakes $\mathrm{Ca}$ was below detection limit (Table 9).

Magnesium is lost between groundwater and lake water sampling sites likely through the precipitation of dolomite or dolomitization of calcite. The saturation index for dolomite calculated using PHREEQC shows that all the lakes are supersaturated with respect to dolomite. Futhermore, dolomite was found in the XRD analysis of sediments from Tsaidam-2 Lake and Tsaidam-1 Lake. The sediment digest procedure dissolved equal concentrations of $\mathrm{Ca}$ and $\mathrm{Mg}$ implying that dolomite was dissolved (Figure 19).

The ratio of $\mathrm{Mg} / \mathrm{Ca}$ increases due to the precipitation of gypsum or anhydrite. When this ratio exceeds about 0.6, calcite is converted to dolomite according to Equation 3:

$$
2 \mathrm{CaCO}_{3}+\mathrm{Mg}^{2+}=\mathrm{CaMg}\left(\mathrm{CO}_{3}\right)_{2}+\mathrm{Ca}^{2+}
$$


Figure 20 shows that lakes Tsaidam- 1 and Tsaidam- 2 both have $\mathrm{Mg} / \mathrm{Ca}$ ratios that exceed 0.6 and in both of these lakes dolomite was found in the XRD analysis (Table 17). Calcium was below the detection limit for all other lakes so dolomitization is expected to occur in these lakes though it was not detected in the XRD analyses.

The $\mathrm{Ca}$ released by dolomitization precipitates as gypsum or anhydrite once saturation is reached for gypsum (Drever 1997). Anhydrite is preferentially formed over gympsum in the high salinities of brines. Gypsum and anhydrite are related by Equation 4.

$$
\begin{gathered}
\mathrm{CaSO}_{4} \cdot 2 \mathrm{H}_{2} \mathrm{O}=\mathrm{CaSO}_{4}+2 \mathrm{H}_{2} \mathrm{O} \\
\mathrm{Keq}=\alpha_{\mathrm{H} 2 \mathrm{O}^{2}}
\end{gathered}
$$

The activity of water in concentrated brines is significantly less than 1 and so gypsum dehydrates to anhydrite. XRD analysis of sediment from Gurvany-1 Lake found anhydrite.

A loss of Si was seen between most of the groundwaters and corresponding lakes (Figure 21). Sepiolite $\left(\mathrm{Mg}_{2} \mathrm{Si}_{3} \mathrm{O}_{7.5}(\mathrm{OH})_{8} 2 \mathrm{H}_{2} \mathrm{O}\right)$ is a likely phase for the loss of $\mathrm{Si}$ in the lake waters. PHREEQC modeling of evaporation in Shar Burdiin Lake indicates that sepiolite becomes supersaturated in lake water after $25 \%$ evaporation (Table 23). However, sepiolite was not discovered in the XRD or ESEM analyses. Kaolinite $\left(\mathrm{Al}_{2} \mathrm{Si}_{2} \mathrm{O}_{5}(\mathrm{OH})_{4}\right)$ may be a more likely mineral to explain the loss of $\mathrm{Si}$ between groundwater and lake water as all water samples are supersaturated with Kaolinite. 
Many elements behave conservatively between groundwaters and lake waters. The PHREEQC evaporation model (Figure 22) shows $\mathrm{Na}, \mathrm{S}$ and $\mathrm{K}$ concentrations increasing at the same rate as $\mathrm{Cl}^{-}$and $\mathrm{Br}^{-}$during evaporation. Many trace metals including $\mathrm{U}$ also behave conservatively between the groundwaters and lake waters (Figure 12).

Upon the complete desiccation of the soda lakes, the dissolved constituents are either precipitated into mineral phases in lake sediments or incorporated into salts. The ratio of U to TIC in the dissolved salt crystal from Gurvany-2 Lake is in line with the water samples (Figure 13). While this may suggest the precipitation of rutherfordine (Table 2), U mineral phases are generally easily mobilized in oxic environments (Langmuir 1978) and so the process of dissolving the salt sample could have mobilized a variety of $\mathrm{U}$ precipitates which would account for the correlation between TIC and U.

\subsection{Lake and Pore Water}

A decrease in $\mathrm{Fe}_{\mathrm{T}}$ was observed between the lake water and pore waters (Figure 23). A likely explanation for this is the lowering of redox potential along with the increase in $\mathrm{pH}$ in lake sediments, which may cause the precipitation of an Fe phase. The Fe phase diagram created using Geochemist's Workbench ${ }^{\circledR}$ (Figure 24), shows that hematite precipitates with increasing $\mathrm{pH}$ and decreasing pe in conditions similar to the soda lakes. PHREEQC modeling determined that lake waters are supersaturated with respect to hematite and the evaporation models show an increase in the SI of hematite (Table 23). Siderite $\left(\mathrm{FeCO}_{3}\right)$ and magnetite $\left(\mathrm{Fe}_{3} \mathrm{O}_{4}\right)$ are also predicted to be 
supersaturated in lake waters (Table 21) and may represent additional sinks for $\mathrm{Fe}_{\mathrm{T}}$ in the lake sediments. The precipitation of an Fe mineral is further supported by the sediment digest results. High concentrations of $\mathrm{Fe}_{\mathrm{T}}$ (Table 19) obtained through the digestion procedure indicate that a Fe mineral phase dissolved. However, an Fe mineral phase was not found in the XRD analyses.

Another factor that may be influencing the Fe content in lake water is the microbial reduction of Fe. Zavarzina and Kolganova (2006) discovered an alkaliphilic member of the geobacteraceae family in a soda lake in Tuva, Russia (Zavarzina et al. 2006). Because Tuva, located on the northern border of Mongolia, shares many climate and latitude similarities with Mongolia, this species of geobacteraceae may be present in the sediments of the soda lakes of eastern Mongolia.

Sulfate generally increased between the lake and the pore waters. This may also be the result of the increasing $\mathrm{pH}$ in lake sediments. Figure 25, showing the speciation of $\mathrm{SO}_{4}{ }^{-2}$, indicates that pyrite may dissolve with increasing $\mathrm{pH}$ and lowering pe.

Although Si concentrations decrease between groundwaters and lake waters likely through the precipitation of kaoline, sepiolite, and other silicates, Si increases in lake pore waters (Figure 21). Because silicate solubility increases with $\mathrm{pH}$ (Brady and Walther 1989), the observed increase in $\mathrm{pH}$ with depth in lake sediment likely causes the dissolution of silicates and accounts for the increase in $\mathrm{Si}$.

In general, elemental concentrations in sediment pore waters show less extreme variation than lake waters. PHREEQC modeling shows that many minerals are near 
equilibrium in the lake waters. This implies that minerals are either precipitating or dissolving, which may keep an elemental balance in the pore waters.

For example, $\mathrm{U}$ concentration is extremely high in Shar Burdiin Lake water but is much lower in the sediment pore waters. This water is predicted to precipitate carnotite (Table 2) after $\sim 20 \%$ evaporation. Conversely Tsiadam-1 Lake had very low $\mathrm{U}$ concentration in lake water but relatively high $\mathrm{U}$ concentration in its pore water (Figure 12). This may be the result of a dissolving U-mineral phase in the pore waters which increases $\mathrm{U}$ concentrations in the pore waters.

\subsection{Uranium Geochemistry}

The soda lakes in eastern Mongolia are unique in their extremely high $\mathrm{U}$ concentrations. Shar Burdiin Lake may have the highest concentrations of naturally occurring $\mathrm{U}\left(62 \mu \mathrm{mol} \mathrm{L} \mathrm{L}^{-1}, 15,000 \mathrm{ppb} \mathrm{U}\right)$ ever found in a natural water. Mono Lake, where $\mathrm{U}$ was also found to be extremely high, $\mathrm{U}$ concentrations are $\sim 1.37 \mu \mathrm{mol} \mathrm{L}^{-1}$ (325 ppb U) (Simpson et al. 1982).

The speciation of $U$ in groundwater and lake water completed in PHREEQC, found that the majority of $U$ in the soda lakes and groundwaters is complexed with carbonate as $\mathrm{UO}_{2}\left(\mathrm{CO}_{3}\right)_{3}^{-4}$. This strong $\mathrm{U}(\mathrm{VI})$-carbonate complex accounts for the stability and solubility of $U$ and the observation of $U$ behaving conservatively through the evaporation of the soda lakes. The stability field of U(VI)-carbonate complexes was verified using Geochemist's Workbench ${ }^{\circledR}$ speciation diagram (Figure 2). Furthermore, there is a correlation between $\mathrm{U}$ and TIC (Figure 13) indicating that both $\mathrm{U}$ and 
carbonates behave conservatively during evaporation between groundwater and lake water.

In general, lakes and their related groundwaters are both either high or low in $\mathrm{U}$ concentrations (Figure 12). Shar Burdiin Lake and Gurvany-2 Lake had the highest U concentrations; Shar Burdiin Well, which is within the catchment area of these two lakes, contains the second highest $U$ concentration of the groundwaters measured. The one exception was Tsiadam-2 Lake which, of the lakes, had the lowest $U$ concentrations and the nearest well, Tsaidam-2 Well, had the highest $\mathrm{U}$ concentrations of the groundwaters. Uranium concentrations in Tsaidam-2 Well are actually higher than in Tsaidam-2 Lake. A possible explanation for this is that Tsaidam-2 Well is not related to the water in Tsaidam-2 Lake, which is confirmed upon close examination of the slope layer created in ArcGIS (Figure 8). Tsaidam-2 Well likely represents groundwater flowing to the northeast to an unsampled basin.

\subsection{Uranium Precipitation}

Uranium decreases between lake and sediment pore waters in Shar Burdiin Lake and Gurvany-2 Lake. These two lakes share the same catchment area and exhibit similar chemistry. While $\mathrm{U}$ decreases by a factor of eight between lake water and sediment pore water in Shar Burdiin Lake, $\mathrm{Cl}^{-}$and $\mathrm{Br}^{-}$decrease by three and four times, respectively. In Gurvany-2 Lake, the loss of $\mathrm{U}$ is closer to two times while $\mathrm{Cl}^{-}$remains almost identical and $\mathrm{Br}^{-}$slightly increases. In these two lakes this loss of $\mathrm{U}$ cannot be easily explained by conservative behavior through evaporation as $\mathrm{Cl}^{-}$and $\mathrm{Br}^{-}$remain relatively similar 
between lake and pore waters. This finding suggests that $U$ is precipitated in the sediments of both Shar Burdiin Lake and Gurvany-2 Lake. This implies that water in these lakes may be supersaturated with a $\mathrm{U}$ mineral phase.

In all other lakes sampled the opposite relationship was observed with $\mathrm{U}$ increasing in the pore waters relative to the lake water, and in every case, the percent increase was greater for $\mathrm{U}$ than for $\mathrm{Cl}^{-}$. In Gurvany-1 Lake and Tsaidam-2 Lake, $\mathrm{U}$ increases in pore waters by a factor of ten while $\mathrm{Cl}^{-}$increases by a factor of two. For Tsiadam-1 Lake, which has the lowest salinity and $\mathrm{U}$ concentrations, $\mathrm{U}$ and $\mathrm{Cl}^{-}$both increase in the pore waters by a factor of about four. This suggests that a $\mathrm{U}$ mineral phase is dissolving in the pore waters in Gurvany-1 Lake while there may be no U-phase mineral in Tsiadam-1 Lake.

The PHREEQC evaporation model demonstrates that several $U$ phases become supersaturatated during the evaporation of Shar Burdiin Lake. It should be noted that halite, found in the ESEM analysis of the salt crust, precipitates after about $75 \%$ evaporation of Shar Burdiin Lake after two U mineral phases (carnotite at $20 \%$ and tyuyamjunite at $40 \%$ ) become supersaturated (Table 23 ). At $80 \%$ evaporation, rutherfordine is also predicted to be supersaturated.

The mobility of $\mathrm{U}$ is sensitive to the presence of $\mathrm{V}$. With greater than $2 \mu \mathrm{mol} \mathrm{L} \mathrm{L}^{-1}$ of $\mathrm{V}, \mathrm{U}$ becomes insoluble through carnotite precipitation under all redox conditions between $\mathrm{pH}$ of 4-8 (Langmuir 1978). Vanadium concentrations in groundwaters are below $2 \mu \mathrm{mol} \mathrm{L}{ }^{-1}$; however, in lake waters where the $\mathrm{pH}$ is above $8, \mathrm{~V}$ is between 3.82 $26 \mu \mathrm{mol} \mathrm{L}{ }^{-1}$. Geochemist's Workbench ${ }^{\circledR}$ was used to speciate $\mathrm{U}$ in the presence of $\mathrm{V}$ 
and $\mathrm{HCO}_{3}{ }^{-}$using activities calculated by PHREEQC for Shar Burdiin Lake (Figure 14). This model shows that even at the high $\mathrm{pH}$ and elevated $\mathrm{HCO}_{3}{ }^{-}$concentrations of the soda lake, only a slight decrease in redox potential will cause carnotite to precipitate.

In anoxic ocean sediments, $U$ is drawn into sediments through a concentration gradient established by the precipitation of an insoluble phase which forms by the reduction of U(VI) to U(IV) (Klinkhammer and Palmer 1991). A similar pathway for $\mathrm{U}(\mathrm{VI})$ reduction may be taking place in Shar Burdiin Lake and Gurvany-2 Lake where U concentrations are significantly higher in lake waters than in pore waters.

Uranium reduction can be initiated by $\mathrm{SO}_{4}^{-2}$ and Fe reducing bacteria (Lovley et al. 1991; Tebo and Obraztsova 1998). A strong rotten egg smell in lake sediments suggests the presence of $\mathrm{HS}$ and the possibility of microbially-driven $\mathrm{SO}_{4}{ }^{2-}$ reduction. However, no evidence for microbial reduction of $U$ was found in the MPN analysis; suggesting that the formation of $U$ mineral phase may not be a microbial process in the investigated lakes.

The sediment digestion procedure also supports that at least a small amount of $\mathrm{U}$ is in a mineral phase. If carnotite was dissolved, $\mathrm{U}$ would likely correlate to $\mathrm{V}$ or $\mathrm{K}$; however, the high concentration of $\mathrm{V}$ and $\mathrm{K}$ derived from the sediment digest procedure overwhelms the $\mathrm{U}$ and so comparisons cannot be made.

\subsection{Source for Uranium in Soda Lakes and Groundwaters}

The phenomenon of $U$ occurring in high abundances in soda lakes has not been well studied and has never been correlated to non-nuclear fallout U. Mono Lake, 
California is the only other soda lake where $\mathrm{U}$ concentrations were found to be extremely high. However, in Mono Lake high U concentrations ( $\sim 325 \mathrm{ppb} \mathrm{U})$ are derived from fallout from above ground nuclear weapon testing (Simpson et al. 1982). This was determined by correlating measurements of nuclide activities derived from atmospheric testing of nuclear weapons $\left({ }^{239,}{ }^{240} \mathrm{Pu},{ }^{238} \mathrm{Pu},{ }^{137} \mathrm{Cs},{ }^{90} \mathrm{Sr}\right.$, and $\left.{ }^{3} \mathrm{H}\right)$ to $\mathrm{U}$ isotope abundances (Simpson et al. 1982).

Fallout from atmospheric nuclear testing in the former USSR is possible source for $\mathrm{U}$ in the Mongolia soda lakes. During the Cold War, the USSR tested 116 above ground nuclear weapons at the Semipalatinsk testing site in eastern Kazakhstan, approximately 2,000 km west of the field site in eastern Mongolia (Shoikhet et al. 2002). Because of prevailing winds and the large amount of $U$ that was ejected into the atmosphere, it is possible that the source of $U$ in these lakes is in part due to nuclear weapons testing.

Uranium isotopes can be used to determine whether high concentrations of $\mathrm{U}$ are sourced from nuclear weapons testing (Seiler 2004). Uranium fissile material used in nuclear weapons typically contains ${ }^{238} \mathrm{U} /{ }^{235} \mathrm{U} \sim 0.17$ (Sublette 2001). In naturally occurring $\mathrm{U}$, the ratio of ${ }^{238} \mathrm{U} /{ }^{235} \mathrm{U}$ is 137.88 (Jaffey et al. 1971). In the present study, the ${ }^{238} \mathrm{U} /{ }^{235} \mathrm{U}$ ratio is $136 \pm 2$ (Table 16 ). This demonstrates that $\mathrm{U}$ is predominantly naturally occurring and not from above ground nuclear testing.

Uranium contamination from nearby mining is another possible source for $\mathrm{U}$ in the soda lakes. Knutson and $\mathrm{Tu}(1996)$ demonstrated that airborne $\mathrm{U}$ particles from $\mathrm{U}$ mining and milling industry can increase natural $U$ concentrations in the air. The 
geological unit the lakes are situated in contains several significant $\mathrm{U}$ deposits (Agnerian et al. 2007), and it is possible there may be unknown deposits within the catchment area of one or more of the studied lakes. If this is the case, the carbonated waters could easily leach $\mathrm{U}$ from the deposits and concentrate it in the lakes.

\subsection{Uranium Isotopes}

Radioactive ${ }^{234} \mathrm{U}$ is formed from the decay of long-lived ${ }^{238} \mathrm{U}$ through two shortlived intermediate isotopes. The amount of ${ }^{234} \mathrm{U}$ is therefore limited by decay of ${ }^{238} \mathrm{U}$, meaning that the two $\mathrm{U}$ nuclides should have identical radioactivity in natural materials. Natural waters, however, typically have an activity ratio of ${ }^{234} \mathrm{U} /{ }^{238} \mathrm{U}$ significantly greater than 1.0 (secular equilibrium) due to the physical process of alpha-recoil during the energetic decay of ${ }^{234} \mathrm{Th}$ (Kigoshi 1971) or by preferential leaching of ${ }^{234} \mathrm{U}$ from radiation-damaged areas (Rosholt et al. 1963). Generally, ${ }^{234} \mathrm{U}$ will increase along a flow path but will vary depending on flow characteristics and the age of the water (Dickson and Davidson 1985). ${ }^{238} \mathrm{U}$ has been shown to be more soluble in oxidizing recharge areas in sandstones and limestone aquifers, while further along the flow path, under more reducing conditions, the solubility of ${ }^{238} \mathrm{U}$ decreases and therefore $\delta^{234} \mathrm{U}$ is lowered (Andrew and Kay 1983). The abundance of $\delta^{234} \mathrm{U}$ along a flow path is therefore variable and dependent on the type of aquifer, redox conditions, and age of the water.

Henderson et al. (2005) found significant enrichment in $\delta^{234} U$ in salt lakes in the Dry Valleys of Antarctica. This was the case as long as the salt lakes had a large area of sediment to interact with and $\mathrm{U}$ had been present in abundance for several thousand 
years. However, in small lakes with less sediment, Henderson et al. (2005) determined that $\delta^{234} U$ in lake waters is representative of the water within the lake's catchment area.

It is possible that the $\mathrm{U}$ isotope composition of water in the two lakes and their related groundwaters demonstrate two separate processes. Shar Burdiin Lake and its corresponding groundwater, showed very little difference in $U$ isotopic composition. In contrast, the difference in $U$ isotopes between Tsaidam-2 Lake and Tsiadam-2 Well 1 is extreme. Shar Burdiin Lake is a small, shallow, hypersaline lake with a small catchment area. In contrast, Tsaidam-2 Lake is larger, less saline and has a bigger catchment area. It is possible that recoil during alpha decay of ${ }^{238} \mathrm{U}$ in the lake sediments is enriching the surface water in Tsaidam-2 Lake in ${ }^{234} U$. Henderson et al. (2005) showed that given sufficient time and water rock interactions, surface waters of large terminal saline lakes can become enriched in ${ }^{234} \mathrm{U}$ by alpha recoil of ${ }^{238} \mathrm{U}$ in lake sediments. While alpha recoil may help explain Tsaidam-2 Lake and its correlated groundwater, the small difference in $\delta^{234} U$ between Shar Burdiin Lake and Shar Burdiin Well is similar to results of Henderson et al. (2005) where smaller saline lakes tended to have $\delta^{234} U$ values representative of their catchment areas.

Figure 30 of $\mathrm{U} / \mathrm{Ca}$ vs. $\delta^{234} \mathrm{U}$ shows that as $\mathrm{U}$ increases and $\mathrm{Ca}$ decreases during the evolution of the soda lakes, an increase in $\delta^{234} U$ is observed. This suggests that $\delta^{234} U$ may be increasing along groundwater flow paths and during the evolution of the lakes. Similarly Figure 29, which shows ${ }^{87} \mathrm{Sr} /{ }^{86} \mathrm{Sr}$ vs. $\delta^{234} \mathrm{U}$, the ${ }^{87} \mathrm{Sr} /{ }^{86} \mathrm{Sr}$ ratio is lower when $\delta^{234} \mathrm{U}$ is higher. Shar Burdiin and Tsaidam-2 Lakes both have lower ${ }^{87} \mathrm{Sr} /{ }^{86} \mathrm{Sr}$ values and higher $\delta^{234} \mathrm{U}$ values than their corresponding groundwater samples. This suggests that in 
these two catchment areas, groundwater travel and lake evolution decreases the ${ }^{87} \mathrm{Sr} /{ }^{86} \mathrm{Sr}$ ratio while simultaneously waters are enriched in higher $\delta^{234} U$. This finding is consistent with alpha recoil of ${ }^{238} \mathrm{U}$ enriching older water with $\delta^{234} \mathrm{U}$ during groundwater flow and during the evolution of the lakes.

\subsection{Strontium Isotopes}

Strontium isotopes have proven to be a useful tool in determining water-rock interactions, as a tracer for groundwater movement, and in determining the origins of water or of salinity (McNutt et al. 1984; Banner et al. 1989; Anderson et al. 1992; Krishnawami et al. 1992; Banner et al. 1994; Lyons et al. 1995). The ${ }^{87} \mathrm{Sr} /{ }^{86} \mathrm{Sr}$ value of natural water can be used as a tracer because the rock the water has been in contact with introduces the ${ }^{87} \mathrm{Sr} /{ }^{86} \mathrm{Sr}$ isotopic signature to the water. Furthermore, unlike other isotopic systems that are affected by evaporation, the ${ }^{87} \mathrm{Sr} /{ }^{86} \mathrm{Sr}$ ratio is generally only affected by water rock interactions.

In general, because felsic rocks are enriched in $\mathrm{K}$ relative to mafic rocks, ${ }^{87} \mathrm{Sr} /{ }^{86} \mathrm{Sr}$ ratios are higher in waters in contact with granitic rocks. Rocks that are enriched in $\mathrm{K}$ have more ${ }^{87} \mathrm{Rb}$ because $\mathrm{Rb}$ behaves similarly to $\mathrm{K}$ in magmas. ${ }^{87} \mathrm{Rb}$ is the parent isotope of ${ }^{87} \mathrm{Sr}$ so rocks with high $\mathrm{Rb}$ content will become enriched in radiogenic ${ }^{87} \mathrm{Sr} /{ }^{86} \mathrm{Sr}$. Similarly, older rocks have higher ${ }^{87} \mathrm{Sr} /{ }^{86} \mathrm{Sr}$ ratios than younger rocks given a similar $\mathrm{Rb} / \mathrm{Sr}$ ratio in the rocks (Banner 2004) Simultaneously, $\mathrm{Sr}$ behaves similarly to $\mathrm{Ca}$, so $\mathrm{Sr}$ is more closely associated with Ca bearing minerals and rocks (Faure and Powell 1972). Silicate rocks generally have low strontium content and higher ${ }^{87} \mathrm{Sr} /{ }^{86} \mathrm{Sr}$ ratios while 
limestones are typically less radiogenic but with more strontium (Brass 1976; Wadleigh and Brooks 1985). Conversely mafic rocks have a markedly lower ${ }^{87} \mathrm{Sr} /{ }^{86} \mathrm{Sr}$ ratio. Present day mantle and ocean crust has a low ${ }^{87} \mathrm{Sr} /{ }^{86} \mathrm{Sr}$ ratio of $\sim 0.703 \pm 1$ whereas the bulk of continents is enriched in radiogenic ${ }^{87} \mathrm{Sr} /{ }^{86} \mathrm{Sr} \sim 0.710$ (Faure and Powell 1972).

In continental waters the ratio of ${ }^{87} \mathrm{Sr} /{ }^{86} \mathrm{Sr}$ reflects the continental crust from which the strontium has been released (Ingram and Sloan 1992). In groundwaters, the ${ }^{87} \mathrm{Sr} /{ }^{86} \mathrm{Sr}$ ratio is dependent upon the type of rocks the water is flowing through and can be used to differentiate regional groundwater systems (Lyons, 1995). In lake waters, the ${ }^{87} \mathrm{Sr} /{ }^{86} \mathrm{Sr}$ ratio is representative of a mixture of $\mathrm{Sr}$ from incoming groundwaters and surface waters (in a gaining lake), as well as interaction with of the rocks within the lake basin (Jones and Faure 1978)

Inland saline lakes will have a strontium isotope ratio representative of the rocks within the basin the brine is formed in (Jones and Faure 1978). In the pore waters of lake sediments of salt lakes, the ${ }^{87} \mathrm{Sr} /{ }^{86} \mathrm{Sr}$ ratio can vary considerably even over the space of tens of centimeters (Lyons et al. 1988). This is thought to demonstrate the large amount of mixing that can take place in groundwater below salt lakes because of density driven processes, input from groundwaters from several sources, and the mineralogical heterogeneity of lake-bottom sediments.

\subsubsection{STRONTIUM BEHAVIOR}

Strontium does not behave conservatively during the evolution of the lake waters. There is a decrease in strontium observed between all lake and pore waters (Figure 26). 
PHREEQC speciation of lakewaters determined that strontianite $\left(\mathrm{SrCO}_{3}\right)$ is supersaturated in all sampled lakes (Table 21). The evaporation model of Shar Burdiin Well showed that strontianite is undersaturated in well waters but becomes supersaturated after $90 \%$ evaporation of well waters (Table 22). Furthermore, strontianite is supersaturated in all of the lakes (Table 21). It is therefore likely that strontium is lost during evaporation of lakes through the precipitation of strontianite. This would account for the non-conservative behavior of strontium between the wells, lakes, and lake pore waters. Furthermore, strontium is likely lost through the precipitation of calcite and anhydrite during the evolution of the lakes though to a much smaller degree than strontium minerals.

\subsubsection{STRONTIUM ISOTOPES IN GROUNDWATER}

The large variation in strontium isotopes in groundwaters suggests that there are two end member geological units through which water is flowing. All the wells sampled were situated in loess. This loess, composed predominately of silicates and carbonates (Dodonov 1991), and the local alkaline rhyolites, likely have a high ${ }^{87} \mathrm{Sr} /{ }^{86} \mathrm{Sr}$ value. Mafic rocks in the region (Agnerian et al. 2007) likely account for the much lower ${ }^{87} \mathrm{Sr} /{ }^{86} \mathrm{Sr}$ end member found in the background well.

Generally wells with high ${ }^{87} \mathrm{Sr} /{ }^{86} \mathrm{Sr}$ also have high abundances of $\mathrm{V}$, As, and $\mathrm{U}$. These groundwater samples, which include Shar Burdiin Well, Tsaidam-1 Well and Gurvany Stream, are likely influenced by Cretaceous siliceous volcanic rocks which are imparting both high ${ }^{87} \mathrm{Sr} /{ }^{86} \mathrm{Sr}$ isotopic values and incompatible elements to the 
groundwaters. There is also a general correlation between increasing $\mathrm{Ca}$ and $\mathrm{Mg}$ concentration and lower ${ }^{87} \mathrm{Sr} /{ }^{86} \mathrm{Sr}$ isotopic value in groundwaters (Figure 28, Table 24). This suggests that these less radiogenic groundwaters are influenced by the local Cretaceous mafic volcanics that are imparting higher $\mathrm{Ca}, \mathrm{Mg}$, and lower ${ }^{87} \mathrm{Sr} /{ }^{86} \mathrm{Sr}$ values to the groundwaters.

\subsubsection{STRONTIUM ISOTOPES IN LAKES}

Despite the large range in strontium isotopes in groundwaters and lake waters, there is good correlation between lakes and the groundwater sampled within the catchment area of each lake (Table 4). Strontium isotopes in groundwater samples are either slightly higher or slightly lower than values for their corresponding discharge lakes.

Strontium isotope values in lakes correlate well with $\mathrm{K}, \mathrm{Cl}^{-}, \mathrm{Na}$, and $\mathrm{U}$ (Table 25), (Figure 27). Lakes with more radiogenic ${ }^{87} \mathrm{Sr} /{ }^{86} \mathrm{Sr}$ have higher $\mathrm{K}, \mathrm{Na}, \mathrm{Cl}^{-}$, and $\mathrm{U}$ concentrations. This likely relates to influences from the Cretaceous alkaline rhyolites, which are expected to have a higher ${ }^{87} \mathrm{Sr} /{ }^{86} \mathrm{Sr}$ ratio and elevated concentrations of $\mathrm{K}, \mathrm{Cl}^{-}$, Na, and U. Furthermore, Shar Burdiin and Guvany-2 lakes which had the highest ${ }^{87} \mathrm{Sr} /{ }^{86} \mathrm{Sr}$ ratio, are also the most alkaline lakes. This correlation between strontium isotopes and $\mathrm{K}, \mathrm{Na}, \mathrm{Cl}^{-}$, and $\mathrm{U}$ may be the result of the high solubility of silicates at high pH (Brady and Walther 1989). Intense weathering of silicates at high $\mathrm{pH}$ may increase the rate at which lake waters are imparted with the higher ${ }^{87} \mathrm{Sr} /{ }^{86} \mathrm{Sr}$ ratio of the silicates in lake sediment while simultaneously leaching $\mathrm{U}$ from the local rocks. 


\subsection{Hydrogeology}

All groundwaters are $\mathrm{Na}-\mathrm{Cl}-\mathrm{HCO}_{3}$ type waters (Figure 7). Similar to the findings of Tsujimura (2007), the Kherlen River is more dilute than the sampled groundwaters and is a $\mathrm{Ca}-\mathrm{HCO}_{3}$ type water (Table 10$)$. This implies that the contributing water to the Kherlen River is likely not related to the groundwaters in the investigated area near Choibalsan.

The semi arid environment and the unequal distribution of precipitation throughout the year means that goundwater recharge in eastern Mongolia is a relatively rare event. (Onodera 1996) showed that in a semi-arid region in Tanzania, central Africa, rainfall events less than $15 \mathrm{~mm}$ did not contribute to groundwater recharge because rainwater evaporated near the soil surface. Furthermore, Tsujimura (2007) found by comparing oxygen and deuterium isotopes in groundwaters in eastern Mongolia to large and small rainfall events, that the region's groundwater is likely only recharged from large rainfall events.

The many springs observed above the lakes indicate that total head in the salt lakes may be higher than lake surface levels. In particular Shar Burdiin Lake, the most saline and dense lake investigated, had many small springs surrounding the lake shore. These springs are direct evidence of discharging groundwaters to the lakes. 


\section{IMPLICATIONS}

\subsection{Wind Blown Uranium}

During the spring expedition in May, 2006, a massive dust storm occurred while sampling in Gurvany-1 Lake. The author observed massive amounts of white salts from the edges of the lake rise and be carried by the prevailing winds. The high proportion of salt in the dust storm was vividly apparent as the dust storm turned white upon reaching Gurvany-1 Lake.

When lake waters completely desiccate, $\mathrm{U}$ is likely incorporated into precipitated salts in a $\mathrm{U}$ mineral phase. These salts containing high concentrations of $U$ (Figure 13) are subject to wind transportation and likely spread U-rich salts for hundreds of kilometers during the massive dust storms that originate in eastern Mongolia (Husa et al. 2001). Furthermore, dust storms are most frequent during the spring when the soda lakes are the driest and most likely to be covered in salts (Zhang et al. 2003). During the May sampling expedition Shar Burdiin Lake was completely dry (Figure 5) and Gurvany-1 Lake was far more saline than in August (Figure 31). Salts were observed coating grasses and soils up to a hundred kilometers from the edges of the salt lakes. Salts from the soda lakes will likely contaminate the soils closer to the lakes with carbonate salts and high concentrations of U. During heavy rainfall events, it is possible that these salts with high concentrations of $\mathrm{U}$ infiltrate to the groundwater and assuming a low redox zone is not encountered, the $\mathrm{U}$ will discharge back into the soda lakes. 
It is possible that wind blown salts from Shar Burdiin Lake and Gurvany-2 Lake contaminate the lakes and groundwaters in the rest of the field area with U. Further evidence for this is suggested by the observation that $U$ concentrations in lakes generally decrease with distance from Shar Burdiin Lake and Gurvany-2 Lake. A dramatic reduction in $\mathrm{U}$ concentrations is seen in Tsaidam-2 Lake and Gurvany-1 Lake which are both over $15 \mathrm{~km}$ from Shar Burdiin Lake (Figure 1).

Soda lakes are not an ideal place to find normal U-reducing microorganisms. The $\mathrm{pH}$ of a solution profoundly affects $\mathrm{U}$ uptake by microorganisms. The optimum $\mathrm{pH}$ range for most organisms that enzymatically reduce $U$ is generally between 3-6 (Suzuki and Banfield 2004). However, an alkaliphilic species of geobacteraceae was found in a soda lake in Tuva, Russia (Zavarzina et al. 2006) which is only several hundred miles from the present field site in eastern Mongolia. It is not unlikely that there may be a geobacteraceae yet to be discovered that survives in hypersaline soda lakes and can enzymatically reduce U(VI). Further study of the lake sediments may reveal that bacteria are playing a role in the reduction of $\mathrm{U}$. Furthermore, the loss of iron between lake water and the sediment pore water suggests iron reduction is taking place in the sediments. U(VI) reduction occurs directly following the reduction of iron (Lovley et al. 1991).

\subsection{Health Effects of Uranium}

Uranium is toxic to the kidneys and can lead to an increased risk in cancer (Kurttio et al. 2002). The EPA has determined the maximum contaminant level (MCL) for $\mathrm{U}$ at $0.12 \mu \mathrm{mol} \mathrm{L}^{-1}$ in drinking water (EPA 2003). Two of the wells sampled had 
concentrations of $U$ exceeding the EPA standard (Table 12). All wells sampled for this study are used for human and livestock consumption. People and livestock are also likely exposed to high concentrations of $U$ through windblown salts from dried soda lakes. Spring sand storms may also increase $U$ exposure to local herders living near the lakes. The health consequences of these U-rich lakes and groundwaters have not been studied.

High concentrations of $U$ were found in the groundwaters near a soda lake within a childhood leukemia cluster in Fallon, Nevada. Between 1997-2004, 15 cases of acute lymphocytic leukemia and one case of acute myelocytic leukemia have been diagnosed in children and teenagers who live, or have lived, in an area near or in the town of Fallon. While $U$ has not been linked to leukemia, ingestion of $U$ contaminated water for many years is known to cause cancer (EPA 2003). Interestingly, the highest concentrations of groundwater U were are all clustered near a soda lake (Seiler 2004). The lake has not been analyzed for $U$ concentrations but it stands to reason that wind blown salts from this soda lake may be contaminating groundwaters in a similar process to the Mongolian soda lakes. 


\section{CONCLUSIONS}

The extremely high concentrations of $U$ found in the soda lakes are likely sourced from regional alkaline Cretaceous rhyolites. Groundwaters with high concentrations of U discharge to the soda lakes where strong U(VI)-carbonate complexes account for the stability and longevity of the $\mathrm{U}$ in lake waters. During the evaporation of the soda lakes, several geochemical divides cause the loss of $\mathrm{Ca}, \mathrm{Mg}$, and $\mathrm{Si}$ between groundwaters and lake waters. Lakes vary substantially throughout the year in salinity and in elemental concentrations causing the dissolution and precipitation of evaporate minerals. A U mineral phase is expected to precipitate during the evaporation of Shar Burdiin and Gurvany-2 Lakes. Furthermore, a U mineral phase may be dissolving in the lake sediments of Tsiadam-2 and Gurvany-1 lakes. When the lakes desiccate, wind blown Urich salts are potential a source of pollution for the local population.

Large variations in $\mathrm{Sr}$ isotopes demonstrate that groundwaters flow through the local mafic and siliceous volcanic rocks. Low ${ }^{87} \mathrm{Sr} /{ }^{86} \mathrm{Sr}$ values in groundwaters correlate to higher $\mathrm{Mg}$ concentrations suggesting influence from local Cretaceous mafic volcanics. High ${ }^{87} \mathrm{Sr} /{ }^{86} \mathrm{Sr}$ values in lake waters strongly correlate to higher concentrations in $\mathrm{Na}, \mathrm{Cl}^{-}$, $\mathrm{U}$, and $\mathrm{K}$ suggesting influence from local Cretaceous alkaline rhyolites. This also implies that possible contamination from wind blown U-rich dust from $\mathrm{U}$ mining $100 \mathrm{~km}$ to the north is not a major contributor to $U$ in the lakes. $\delta^{234} U$ increases between groundwaters

and lakewaters likely as the result of alpha recoil of ${ }^{238} U$ and leaching of ${ }^{234} U$ during the weathering of minerals in the soda lakes. 
The amount of $U$ found within the waters of the Mongolian soda lakes suggests that soda lakes are an ideal place for the accumulation of $U$ because of complexation with carbonates. The recent discovery of high amounts of $U$ in salts from a soda lake in central Mongolian (Markwitz et al. 2008) suggest that there may be other soda lakes in Mongolia enriched in U. 


\section{TABLES}

Table 1: Equilibrium constants for U(VI)-carbonate complexes from Guillaumont et al. (2003).

\begin{tabular}{|l|l|l|}
\hline & Formula & $\mathbf{K}$ \\
\hline 1 & $\mathrm{UO}_{2}{ }^{2+}+\mathrm{CO}_{3}{ }^{2-} \leftrightarrow \mathrm{UO}_{2} \mathrm{CO}_{3}{ }^{\circ}$ & $10^{9.94}$ \\
\hline 2 & $\mathrm{UO}_{2} \mathrm{CO}_{3}{ }^{\circ}+\mathrm{CO}_{3}{ }^{2-} \leftrightarrow \mathrm{UO}_{2}\left(\mathrm{CO}_{3}\right)_{2}{ }^{-2}$ & $10^{16.61}$ \\
\hline 3 & $\mathrm{UO}_{2}\left(\mathrm{CO}_{3}\right)_{2}{ }^{-2}+\mathrm{CO}_{3}{ }^{2-} \leftrightarrow \mathrm{UO}_{2}\left(\mathrm{CO}_{3}\right)_{3}{ }^{-4}$ & $10^{21.84}$ \\
\hline
\end{tabular}

Table 2: Uranium minerals with associated stability constants and formulas. The stability constant for rutherfordine is from Guillaumont et al. (2003). Stability constants for carnotite and tyuyamunite are from Langmuir (1978).

\begin{tabular}{|l|l|l|l|}
\hline \multicolumn{1}{|c|}{.Phase } & \multicolumn{1}{c|}{ Formula } & \multicolumn{1}{c|}{$\mathbf{K}_{\text {sp }}$} & \multicolumn{1}{c|}{ Rxn } \\
\hline Rutherfordine & $\mathrm{UO}_{2} \mathrm{CO}_{3}$ & $\mathrm{~K}_{\mathrm{sp}}=10^{14.76}$ & $\mathrm{UO}_{2}{ }^{2+}+\mathrm{CO}_{3}{ }^{2-} \leftrightarrow \mathrm{UO}_{2} \mathrm{CO}_{3}$ \\
\hline Carnotite & $\mathrm{K}_{2}\left(\mathrm{UO}_{2}\right)_{2}\left(\mathrm{VO}_{4}\right)_{2}$ & $\mathrm{~K}_{\mathrm{sp}}=10^{-56.9}$ & $2 \mathrm{UO}_{2}{ }^{2+}+2 \mathrm{VO}_{4}{ }^{3-}+2 \mathrm{~K}^{+} \leftrightarrow \mathrm{K}_{2}\left(\mathrm{UO}_{2}\right)_{2}\left(\mathrm{VO}_{4}\right)_{2}$ \\
\hline Tyuyamunite & $\mathrm{Ca}\left(\mathrm{UO}_{2}\right)_{2}\left(\mathrm{VO}_{4}\right)_{2}$ & $\mathrm{~K}_{\mathrm{sp}}=10^{-53.4}$ & $\mathrm{Ca}^{2+}+2 \mathrm{UO}_{2}{ }^{2+}+2 \mathrm{VO}_{4}{ }^{3-} \leftrightarrow \mathrm{Ca}\left(\mathrm{UO}_{2}\right) 2\left(\mathrm{VO}_{4}\right)_{2}$ \\
\hline
\end{tabular}


Table 3: Latitude and longitude of all field sampling locations.

\begin{tabular}{|c|c|c|}
\hline Sample & $\begin{array}{c}\text { Lat } \\
\text { WGS84 } \\
\end{array}$ & $\begin{array}{c}\text { Long } \\
\text { WGS84 }\end{array}$ \\
\hline Tsaidam-2 Well 1 & $\mathrm{~N} 48^{\circ} 07.616$ & $\mathrm{E} 114^{\circ} 27.187$ \\
\hline Tsaidam-2 Well 2 & $\mathrm{~N} 48^{\circ} 07.181$ & $\mathrm{E} 114^{\circ} 22.507$ \\
\hline Tsaidam-2 Lake & $\mathrm{N} 48^{\circ} 07.053$ & $\mathrm{E} 114^{\circ} 24.119$ \\
\hline Gurvany-1 stream & $\mathrm{N} 48^{\circ} 11.637$ & $\mathrm{E} 114^{\circ} 25.509$ \\
\hline Gurvany-1 Lake & $\mathrm{N} 44^{\circ} 11.139$ & $\mathrm{E} 114^{\circ} 25.667$ \\
\hline Shar Burdiin Well & $\mathrm{N} 48^{\circ} 17.461$ & E1 1 $14^{\circ} 30.333$ \\
\hline Shar Burdiin Lake & $\mathrm{N} 48^{\circ} 19.116$ & $\mathrm{E} 114^{\circ} 31.311$ \\
\hline Gurvany-2 Lake & $\mathrm{N} 48^{\circ} 19.704$ & $\mathrm{E} 114^{\circ} 30.737$ \\
\hline Tsaidam-1 Well & N48 30.948 & E11 $14^{\circ} 38.573$ \\
\hline Tsaidam-1 Lake & $\mathrm{N} 48^{\circ} 27.531$ & $\mathrm{E} 114^{\circ} 49.703$ \\
\hline Background Well & $\mathrm{N} 48^{\circ} 37.956$ & $\mathrm{E} 114^{\circ} 33.969$ \\
\hline
\end{tabular}


Table 4: Strontium isotope analyses for groundwaters and lake waters with external and internal precision.

\begin{tabular}{lccc}
\hline Sample & ${ }^{87} \mathbf{S r}{ }^{86} \mathbf{S r}$ & $\begin{array}{c}\text { Internal } \\
\text { Precission } \\
\pm\end{array}$ & $\begin{array}{c}\text { External Precission } \\
\mathbf{( 2 \sigma )} \\
\pm\end{array}$ \\
\hline Tsaidam-2 Well 1 & 0.709569 & 0.000008 & 0.000017 \\
Gurvany-1 Stream & 0.708256 & 0.000008 & 0.000017 \\
Shar Burdiin Well & 0.709776 & 0.000009 & 0.000017 \\
Tsaidam-1 Well & 0.708022 & 0.000008 & 0.000017 \\
Background Well & 0.70612 & 0.000008 & 0.000017 \\
Duplicate sample & 0.706192 & 0.000008 & 0.000017 \\
\hline Tsaidam-2 Lake & 0.708847 & 0.000009 & 0.000017 \\
Gurvany-1 Lake & 0.708702 & 0.000009 & 0.000017 \\
Shar Burdiin Lake & 0.709432 & 0.000008 & 0.000017 \\
Gurvany-2 Lake & 0.709355 & 0.000009 & 0.000017 \\
Tsaidam-1 Lake & 0.708733 & 0.000008 & 0.000017 \\
NIST-SRM-987 (1) & 0.710262 & 0.000008 & 0.000017 \\
NIST-SRM-987 (1) & 0.710264 & 0.000008 & 0.000017 \\
\hline
\end{tabular}


Table 5: Field Parameters for groundwater and lake water sampling sites.

\begin{tabular}{lccccccc}
\hline Sample & $\begin{array}{c}\mathbf{T}_{(\mathrm{Wa})} \\
\left({ }^{\circ} \mathrm{C}\right)\end{array}$ & $\mathbf{p H}$ & $\begin{array}{c}\text { Cond } \\
(\mathrm{mS})\end{array}$ & $\begin{array}{c}\mathbf{E h} \\
(\mathrm{mv})\end{array}$ & $\begin{array}{c}\mathbf{O}_{2} \\
\mathrm{mmol} / \mathrm{L}\end{array}$ & $\begin{array}{c}\mathbf{C h e m e t O}_{2} \\
\mathrm{mmol} / \mathrm{L}\end{array}$ & $\begin{array}{c}\text { Alk } \\
\mathrm{meq} / 1\end{array}$ \\
\hline Tsaidam-2 Well 1 & 11 & 7.44 & 3.02 & -188 & $\mathrm{BDL}$ & 0.1 & 10.8 \\
Tsaidam-2 Well 2 & 5.3 & 7.09 & 3.19 & -25 & $\mathrm{BDL}$ & & \\
Gurvany-1 Stream & 26.6 & 8.49 & 1.46 & 122 & 0.22 & & \\
Shar Burdiin Well & 4.4 & 7.88 & 1.25 & 146 & 0.07 & & \\
Tsaidam-1 Well & 9.4 & 7.97 & 1.43 & 91 & 0.2 & & \\
Background Well & 9.5 & 7.71 & 1.98 & -130 & $\mathrm{BDL}$ & 0.09 & 6.44 \\
Duplicate sample & 13.9 & 7.53 & 1.97 & -117 & $\mathrm{BDL}$ & & \\
\hline Tsaidam-2 Lake & 28.3 & 9.07 & 46.25 & 121 & & & \\
Gurvany-1 Lake & 23.5 & 9.9 & 229.91 & 117 & 0.35 & & \\
Shar Burdiin Lake & 29.6 & 9.77 & 133.2 & 62 & & & \\
Gurvany-2 Lake & 26.2 & 9.68 & 117.8 & 96 & & & \\
Tsaidam-1 Lake & 23.2 & 9.22 & 28.7 & 43 & 0.27 & & \\
\hline
\end{tabular}


Table 6: Laboratory $\mathrm{pH}$, TIC, alkalinity and calculated $\mathrm{CO}_{2}, \mathrm{HCO}_{3}{ }^{-}, \mathrm{CO}_{3}{ }^{2-}$, and NPOC (non-purgable organic carbon) for groundwater and lake water samples.

\begin{tabular}{lccccccc}
\hline Sample & pH(lab) & $\begin{array}{c}\text { TIC } \\
\mathrm{mmol} / \mathrm{L}\end{array}$ & $\begin{array}{c}\text { AlkTIC } \\
\mathrm{mmol} / \mathrm{L}\end{array}$ & $\begin{array}{c}\mathbf{C O}_{2} \\
\mathrm{mmol} / \mathrm{L}\end{array}$ & $\begin{array}{c}\mathbf{H C O}_{3} \\
\mathrm{mmol} / \mathrm{L}\end{array}$ & $\begin{array}{c}\mathbf{C O}_{3} \\
\mathrm{mmol} / \mathrm{L}\end{array}$ & $\begin{array}{c}\text { NPOC } \\
\mathrm{mmol} / \mathrm{L}\end{array}$ \\
\hline Tsaidam-2 Well 1 & 7.17 & 13.1 & 11.4 & 2.1 & 11.4 & 0.01 & \\
Tsaidam-2 Well 2 & 7.6 & 12.9 & 12.2 & 0.87 & 12.10 & 0.02 & 40.2 \\
Gurvany-1 Stream & 8.33 & 10.2 & 10.1 & 0.13 & 9.97 & 0.07 & 14.1 \\
Shar Burdiin Well & 7.97 & 10.9 & 10.7 & 0.33 & 10.60 & 0.03 & 12.1 \\
Tsaidam-1 Well & 8.06 & 9.7 & 9.55 & 0.24 & 9.48 & 0.04 & 10.2 \\
Background Well & 7.39 & 7.7 & 7.07 & 0.81 & 7.05 & 0.01 & 18.6 \\
Duplicate sample & 7.67 & 7.8 & 7.47 & 0.45 & 7.45 & 0.01 & 12.4 \\
\hline Tsaidam-2 Lake & 9.24 & 24.7 & 25.8 & 0.04 & 23.2 & 1.31 & \\
Gurvany-1 Lake & 9.93 & 83.5 & 100 & 0.02 & 64.1 & 18 & \\
Shar Burdiin Lake & 9.84 & 1100 & 1290 & 0.38 & 885 & 202 & \\
Gurvany-2 Lake & 9.83 & 929 & 1080 & 0.33 & 749 & 167 & \\
Tsaidam-1 Lake & 9.21 & 31.4 & 32.8 & 0.05 & 29.60 & 1.56 & \\
\hline
\end{tabular}


Table 7: Dissolved gases for groundwater and lake water samples.

\begin{tabular}{lccccc}
\hline Samlpe & $\begin{array}{c}\mathbf{O}_{\mathbf{2}} \\
\mathrm{mmol} / \mathrm{L}\end{array}$ & $\begin{array}{c}\mathbf{N}_{\mathbf{2}} \\
\mathrm{mmol} / \mathrm{L}\end{array}$ & $\begin{array}{c}\mathbf{A r} \\
\mathrm{mmol} / \mathrm{L}\end{array}$ & $\begin{array}{c}\mathbf{C H}_{\mathbf{4}} \\
\mathrm{mmol} / \mathrm{L}\end{array}$ & $\begin{array}{c}\mathbf{C O}_{\mathbf{2}} \\
\mathrm{mmol} / \mathrm{L}\end{array}$ \\
\hline Tsaidam-2 Well 1 & 0.07 & 0.87 & 0.04 & 0.001 & 1.31 \\
Gurvany-1 Stream & 0.08 & 1.12 & 0.03 & 0.001 & 0.1 \\
Shar Burdiin Well & 0.05 & 0.96 & 0.04 & 0.001 & 0.33 \\
Tsaidam-1 Well & 0.04 & 0.88 & 0.04 & $\mathrm{BDL}$ & 0.59 \\
Background Well & 0.1 & 1.13 & 0.05 & $\mathrm{BDL}$ & 0.46 \\
\hline Tsaidam-2 Lake & 0.36 & 0.6 & 0.03 & $\mathrm{BDL}$ & 0.01 \\
Shar Burdiin Lake & 0.1 & 0.79 & 0.02 & 0.001 & 0.03 \\
\hline
\end{tabular}


Table 8: Anions for groundwater, lake water and pore water samples.

\begin{tabular}{lccccccccc}
\hline Samples & $\begin{array}{c}\mathbf{F} \\
\mathrm{mmol} / \mathrm{L}\end{array}$ & $\begin{array}{c}\mathbf{H C O}_{3} \\
\mathrm{mmol} / \mathrm{L}\end{array}$ & $\begin{array}{c}\mathbf{C O}_{3} \\
\mathrm{mmol} / \mathrm{L}\end{array}$ & $\begin{array}{c}\mathbf{C l} \\
\mathrm{mmol} / \mathrm{L}\end{array}$ & $\begin{array}{c}\mathbf{N O}_{2} \\
\mathrm{mmol} / \mathrm{L}\end{array}$ & $\begin{array}{c}\mathbf{B r} \\
\mathrm{mmol} / \mathrm{L}\end{array}$ & $\begin{array}{c}\mathrm{NO}_{3} \\
\mathrm{mmol} / \mathrm{L}\end{array}$ & $\begin{array}{c}\mathbf{S O}_{4} \\
\mathrm{mmol} / \mathrm{L}\end{array}$ & $\begin{array}{c}\mathbf{P O}_{4} \\
\mathrm{mmol} / \mathrm{L}\end{array}$ \\
\hline Tsaidam-2 Well 1 & 1.42 & 9.82 & 0.01 & 10.80 & $\mathrm{BDL}$ & 0.03 & $\mathrm{BDL}$ & 4.87 & $\mathrm{BDL}$ \\
Tsaidam-2 Well 2 & 0.14 & 9.88 & 0.02 & 8.95 & $\mathrm{BDL}$ & 0.02 & 0.03 & 5.3 & $\mathrm{BDL}$ \\
Gurvany-1 Stream & 0.12 & 9.20 & 0.07 & 2.05 & $\mathrm{BDL}$ & $\mathrm{BDL}$ & $\mathrm{BDL}$ & 1.45 & $\mathrm{BDL}$ \\
Shar Burdiin Well & $\mathrm{BDL}$ & 9.24 & 0.03 & 1.39 & 0.17 & 0.003 & $\mathrm{BDL}$ & 0.99 & 0.01 \\
Tsaidam-1 Well & 9.60 & 7.88 & 0.04 & 2.99 & $\mathrm{BDL}$ & 0.01 & $\mathrm{BDL}$ & 1.13 & 0.002 \\
Background Well & 0.03 & 7.05 & 0.01 & 2.62 & $\mathrm{BDL}$ & $\mathrm{BDL}$ & $\mathrm{BDL}$ & 5.23 & 0.01 \\
Duplicate sample & 0.04 & 6.10 & 0.01 & 2.79 & $\mathrm{BDL}$ & $\mathrm{BDL}$ & $\mathrm{BDL}$ & 5.59 & 0.01 \\
\hline Tsaidam-2 Lake & 1.68 & 23.2 & 1.31 & 376 & $\mathrm{BDL}$ & 0.62 & $\mathrm{BDL}$ & 42.7 & $\mathrm{BDL}$ \\
Gurvany-1 Lake & 2.45 & 64.1 & 18 & 122 & $\mathrm{BDL}$ & 0.23 & $\mathrm{BDL}$ & 53.6 & 0.24 \\
Shar Burdiin Lake & 22.5 & 885 & 202 & 1040 & $\mathrm{BDL}$ & 3.33 & $\mathrm{BDL}$ & 193 & 5.19 \\
Gurvany-2 Lake & 16 & 749 & 167 & 688 & $\mathrm{BDL}$ & 1.92 & $\mathrm{BDL}$ & 134 & $\mathrm{BDL}$ \\
Tsaidam-1 Lake & 2.49 & 30 & 1.56 & 208 & $\mathrm{BDL}$ & 0.8 & $\mathrm{BDL}$ & 23.3 & $\mathrm{BDL}$ \\
\hline Tsaidam-2-pore water & 29.1 & & & 681 & 6.21 & 1.82 & 2.88 & 142 & 34.9 \\
Gurvany-1-pore water & 3.56 & & & 203 & 4.59 & 0.92 & $\mathrm{BDL}$ & 107 & $\mathrm{BDL}$ \\
Shar Burdiin- pore water & 3.25 & & & 420 & 1.16 & 0.85 & 2.51 & 245 & $\mathrm{BDL}$ \\
Gurvany-2 pore water & 5.5 & & & 676 & 5.43 & 2.72 & $\mathrm{BDL}$ & 260 & $\mathrm{BDL}$ \\
Tsaidam-1- pore waters & 3.45 & & & 580 & 3.74 & 1.84 & 0.46 & 99.4 & $\mathrm{BDL}$ \\
\hline
\end{tabular}


Table 9: Major cations for groundwaters, lake waters, and pore waters with results of charge balance calculations. Charge balance was not completed for pore waters because DIC was not measured and $\mathrm{HCO}_{3}{ }^{-}$is a major anion in these waters.

\begin{tabular}{|c|c|c|c|c|c|c|c|c|}
\hline Sample & $\begin{array}{c}\text { B } \\
\mathrm{mmol} / \mathrm{L}\end{array}$ & $\begin{array}{c}\mathbf{N a} \\
\mathrm{mmol} / \mathrm{L}\end{array}$ & $\begin{array}{c}\text { Mg } \\
\mathrm{mmol} / \mathrm{L}\end{array}$ & $\begin{array}{c}\mathbf{S i} \\
\mathrm{mmol} / \mathrm{L}\end{array}$ & $\begin{array}{c}\mathbf{P} \\
\mathrm{mmol} / \mathrm{L}\end{array}$ & $\begin{array}{c}\mathbf{K} \\
\mathrm{mmol} / \mathrm{L}\end{array}$ & $\begin{array}{c}\text { Ca } \\
\mathrm{mmol} / \mathrm{L}\end{array}$ & $\begin{array}{c}\text { CB } \\
\% \\
\end{array}$ \\
\hline Tsaidam-2 Well 1 & 0.05 & 20.8 & 3.86 & 0.6 & 0.06 & 0.16 & 2.42 & $-0.6 \%$ \\
\hline Tsaidam-2 Well 2 & 0.06 & 29.5 & 1.11 & 0.61 & 0.09 & 0.19 & 0.53 & $1.5 \%$ \\
\hline Gurvany-1 Stream & 0.07 & 11.5 & 0.69 & 0.67 & 0.06 & 0.37 & 0.51 & $-3.7 \%$ \\
\hline Shar Burdiin Well & 0.09 & 11.5 & 0.67 & 0.35 & 0.03 & 0.06 & 0.49 & $-1.0 \%$ \\
\hline Tsaidam-1 Well & 0.04 & 10 & 1.89 & 0.33 & 0.03 & 0.07 & 0.73 & $-23.7 \%$ \\
\hline Background Well & 0.02 & 14 & 1.5 & 0.28 & 0.03 & 0.13 & 1.32 & $-1.8 \%$ \\
\hline Duplicate sample & 0.02 & 14 & 1.55 & 0.26 & 0.02 & 0.13 & 2.43 & $0.7 \%$ \\
\hline Tsaidam-2 Lake & 1.07 & 489 & 2.31 & 0.02 & 0.02 & 1.47 & 0.33 & $0.7 \%$ \\
\hline Gurvany-1 Lake & 2.15 & 383 & 1 & 0.08 & 1.28 & 0.41 & BDL & $6.3 \%$ \\
\hline Shar Burdiin Lake & 28.7 & 2430 & 1 & 0.06 & 5.54 & 4.96 & $\mathrm{BDL}$ & $-7.5 \%$ \\
\hline Gurvany-2 Lake & 12.5 & 2160 & 0.83 & BDL & 2.43 & 2.30 & $\mathrm{BDL}$ & $1.0 \%$ \\
\hline Tsaidam-1 Lake & 1.03 & 314 & 0.82 & 0.003 & 0.04 & 1.09 & 0.05 & $4.2 \%$ \\
\hline Tsaidam-2-pore water & BDL & 995 & 1.22 & 0.06 & BDL & 3.39 & 0.15 & \\
\hline Gurvany-1 pore water & BDL & 725 & 0.26 & BDL & 0.87 & 1.73 & BDL & \\
\hline Shar Burdiin pore water & BDL & 1020 & 1.87 & 0.23 & 0.69 & 2.78 & BDL & \\
\hline Gurvany-2 pore water & BDL & 2330 & 0.23 & 0.57 & BDL & 2.02 & BDL & \\
\hline Tsaidam-1 pore waters & BDL & 786 & 1.49 & 0.04 & BDL & 3.12 & 0.17 & \\
\hline
\end{tabular}


Table 10: May sampling of Kherlen River and Gurvany-1 Lake. Results include pH, major cations and anions.

\begin{tabular}{lcccccccccc}
\hline Sample & $\mathbf{p H}$ & $\begin{array}{c}\mathbf{K} \\
\mathrm{mmol} / \mathrm{L}\end{array}$ & $\begin{array}{c}\mathbf{N a} \\
\mathrm{mmol} / \mathrm{L}\end{array}$ & $\begin{array}{c}\mathbf{N H}_{\mathbf{4}} \\
\mathrm{mmol} / \mathrm{L}\end{array}$ & $\begin{array}{c}\mathbf{C a} \\
\mathrm{mmol} / \mathrm{L}\end{array}$ & $\begin{array}{c}\mathbf{C l} \\
\mathrm{mmol} / \mathrm{L}\end{array}$ & $\begin{array}{c}\mathbf{S O}_{4} \\
\mathrm{mmol} / \mathrm{L}\end{array}$ & $\begin{array}{c}\mathbf{N O}_{3} \\
\mathrm{mmol} / \mathrm{L}\end{array}$ & $\begin{array}{c}\mathbf{C O}_{3} \\
\mathrm{mmol} / \mathrm{L}\end{array}$ & $\begin{array}{c}\mathbf{H C O}_{3} \\
\mathrm{mmol} / \mathrm{L}\end{array}$ \\
\hline Gurvany-1 Lake & 9.63 & 2.21 & 1350 & 0.25 & 8.77 & 628 & 153 & 0.10 & 144 & 147 \\
Kherlen River & 7.95 & 0.05 & 2.18 & 0.02 & 0.93 & 0.39 & 0.60 & 0.01 & 0.05 & 2.40 \\
\hline
\end{tabular}


Table 11: Trace metals for groundwater and total metal analyses of groundwater samples. $\mathrm{Fe}_{\mathrm{T}}$ and $\mathrm{As}_{\mathrm{T}}$ means total $\mathrm{Fe}$ and total As.

\begin{tabular}{lccccccccc}
\hline Sample & $\mathbf{L i}$ & $\mathbf{A l}$ & $\mathbf{P}$ & $\mathbf{V}$ & $\mathbf{M n}$ & $\mathbf{F e}_{\mathbf{T}}$ & $\mathbf{C u}$ & $\mathbf{Z n}$ & $\mathbf{A s}_{\mathbf{T}}$ \\
& $\mu \mathrm{mol} / \mathrm{L}$ & $\mu \mathrm{mol} / \mathrm{L}$ & $\mu \mathrm{mol} / \mathrm{L}$ & $\mu \mathrm{mol} / \mathrm{L}$ & $\mu \mathrm{mol} / \mathrm{L}$ & $\mu \mathrm{mol} / \mathrm{L}$ & $\mu \mathrm{mol} / \mathrm{L}$ & $\mu \mathrm{mol} / \mathrm{L}$ & $\mu \mathrm{mol} / \mathrm{L}$ \\
\hline Tsaidam-2 Well 1 & 6.93 & 23.9 & 52.1 & 0.05 & 4.58 & 3.28 & $\mathrm{BDL}$ & 0.32 & 0.15 \\
Tsaidam-2 Well 2 & 5.75 & 2.53 & 79.3 & 0.02 & 3.25 & 12.6 & $\mathrm{BDL}$ & 2.1 & 0.02 \\
Gurvany-1 Stream & 7.47 & $\mathrm{BDL}$ & 51.6 & 1.72 & $\mathrm{BDL}$ & $\mathrm{BDL}$ & $\mathrm{BDL}$ & $\mathrm{BDL}$ & 0.34 \\
Shar Burdiin Well & 1.8 & 21 & 23.7 & 0.55 & 0.79 & 0.72 & 0.07 & 0.89 & 0.35 \\
Tsaidam-1 Well & 4.33 & 36.4 & 27.3 & 0.11 & 0.24 & 0.95 & 0.02 & 1.47 & 0.05 \\
Background Well & 55 & $\mathrm{BDL}$ & 24.1 & 0.02 & 2.74 & 0.13 & 0.06 & $\mathrm{BDL}$ & 0.06 \\
Duplicate sample & 55 & $\mathrm{BDL}$ & 18.9 & 0.01 & $\mathrm{BDL}$ & $\mathrm{BDL}$ & $\mathrm{BDL}$ & 0.01 & 0.06 \\
\hline Tsaidam-2 Well 1 total metals & 0.98 & 69.2 & $\mathrm{BDL}$ & 1.49 & 9.62 & 14.2 & $\mathrm{BDL}$ & 0.19 & $\mathrm{BDL}$ \\
Tsaidam-2 Well 2 total metals & 0.95 & 103 & $\mathrm{BDL}$ & 1.84 & 9.91 & 51.8 & 0.37 & 2.38 & $\mathrm{BDL}$ \\
Gurvany-1 Stream total metals & 0.93 & 2240 & $\mathrm{BDL}$ & 7.31 & 42.9 & 659.0 & 1.02 & 1.67 & 0.79 \\
Shar Burdiin Well total metals & 0.9 & 119 & $\mathrm{BDL}$ & 2.85 & 2.95 & 21.8 & 0.57 & 0.60 & 0.74 \\
Tsaidam-1 Well total metals & 0.92 & 89.7 & $\mathrm{BDL}$ & 1.60 & 0.77 & 9.38 & $\mathrm{BDL}$ & 0.24 & $\mathrm{BDL}$ \\
Background Well total metals & 0.91 & 57.7 & $\mathrm{BDL}$ & 1.10 & 54.3 & 41.2 & $\mathrm{BDL}$ & $\mathrm{BDL}$ & 0.3 \\
Duplicate sample total metals & 0.93 & 46.9 & $\mathrm{BDL}$ & 1.03 & 48.9 & 34 & $\mathrm{BDL}$ & 0.82 & $\mathrm{BDL}$ \\
\hline
\end{tabular}


Table 12: Continued trace metals for groundwater and total metal analyses of groundwater samples.

\begin{tabular}{lccccccccc}
\hline Samples & Se & $\mathbf{R b}$ & $\mathbf{S r}$ & $\mathbf{C o}$ & $\mathbf{B a}$ & $\mathbf{P b}$ & $\mathbf{T h}$ & $\mathbf{U}$ & $\begin{array}{c}\text { U from } \\
\text { TIMS } \\
\end{array}$ \\
& $\mu \mathrm{mol} / \mathrm{L}$ & $\mu \mathrm{mol} / \mathrm{L}$ & $\mu \mathrm{mol} / \mathrm{L}$ & $\mu \mathrm{mol} / \mathrm{L}$ & $\mu \mathrm{mol} / \mathrm{L}$ & $\mu \mathrm{mol} / \mathrm{L}$ & $\mu \mathrm{mol} / \mathrm{L}$ & $\mu \mathrm{mol} / \mathrm{L}$ & $\mu \mathrm{mol} / \mathrm{L}$ \\
\hline Tsaidam-2 Well 1 & BDL & 0.02 & 18.9 & 0.08 & 0.36 & $\mathrm{BDL}$ & $\mathrm{BDL}$ & 0.05 & 0.041 \\
Tsaidam-2 Well 2 & $\mathrm{BDL}$ & 0.03 & 3.85 & 0.06 & 1.22 & $\mathrm{BDL}$ & $\mathrm{BDL}$ & 0.02 & \\
Gurvany-1 Stream & 0.02 & 0.04 & 4.37 & 0.41 & 0.42 & 0.002 & $\mathrm{BDL}$ & 0.21 & \\
Shar Burdiin Well & 0.05 & 0.005 & 3.1 & 0.39 & 0.19 & 0.001 & $\mathrm{BDL}$ & 0.36 & 0.322 \\
Tsaidam-1 Well & 0.03 & 0.02 & 5.74 & 0.43 & 0.17 & $\mathrm{BDL}$ & $\mathrm{BDL}$ & 0.43 & \\
Background Well & $\mathrm{BDL}$ & 0.04 & 2.8 & 0.08 & 0.05 & 0.01 & $\mathrm{BDL}$ & 0.03 & \\
Duplicate sample & 0.005 & 0.04 & 4.07 & 0.08 & 0.01 & $\mathrm{BDL}$ & $\mathrm{BDL}$ & 0.03 & \\
\hline Tsaidam-2 Well 1 total metals & 0.12 & $\mathrm{BDL}$ & 30.5 & $\mathrm{BDL}$ & 0.6 & 0.14 & $\mathrm{BDL}$ & $\mathrm{BDL}$ & \\
Tsaidam-2 Well 2 total metals & 0.12 & $\mathrm{BDL}$ & 8.83 & $\mathrm{BDL}$ & $\mathrm{BDL}$ & 0.11 & $\mathrm{BDL}$ & $\mathrm{BDL}$ & \\
Gurvany-1 Stream total metals & 0.10 & 1.25 & 13.7 & $\mathrm{BDL}$ & 3.86 & 0.29 & 0.17 & 0.34 & \\
Shar Burdiin Well total metals & 0.18 & $\mathrm{BDL}$ & 7.26 & $\mathrm{BDL}$ & 0.57 & 0.15 & $\mathrm{BDL}$ & 0.63 & \\
Tsaidam-1 Well total metals & 0.12 & $\mathrm{BDL}$ & 10.1 & $\mathrm{BDL}$ & $\mathrm{BDL}$ & 0.13 & $\mathrm{BDL}$ & 0.55 & \\
Background Well total metals & 0.23 & $\mathrm{BDL}$ & 7.61 & $\mathrm{BDL}$ & $\mathrm{BDL}$ & 0.12 & $\mathrm{BDL}$ & $\mathrm{BDL}$ & \\
Duplicate sample total metals & 0.07 & $\mathrm{BDL}$ & 6.53 & $\mathrm{BDL}$ & $\mathrm{BDL}$ & 0.14 & $\mathrm{BDL}$ & $\mathrm{BDL}$ & \\
\hline
\end{tabular}


Table 13: pH profile of lake sediments in Tsaidam-1 Lake.

\begin{tabular}{cc}
\hline $\begin{array}{c}\text { Depth } \\
\text { (cm) }\end{array}$ & pH \\
\hline 0 & 9.3 \\
1 & 9.3 \\
6 & 9.4 \\
10 & 9.8 \\
18 & 10.1 \\
20 & 10.3 \\
\hline
\end{tabular}


Table 14: Trace metals for lake water and lake pore water samples.

\begin{tabular}{lccccccccc}
\hline Sample & $\mathbf{L i}$ & $\mathbf{A l}$ & $\mathbf{P}$ & $\mathbf{V}$ & $\mathbf{M n}$ & $\mathbf{F e}-\mathbf{T}$ & $\mathbf{C u}$ & $\mathbf{Z n}$ & $\begin{array}{c}\text { AsT } \\
\mu \mathrm{mol} / \mathrm{L}\end{array}$ \\
& 15.3 & 19.9 & 16.5 & 3.89 & $\mathrm{BDL} / \mathrm{L}$ & $\mathrm{BDL}$ & 0.08 & 6.06 & 3.3 \\
& 5.43 & 51.4 & 1280 & 3.82 & 0.59 & 44.5 & $\mathrm{BDL}$ & $\mathrm{BDL}$ & 9.28 \\
Tsaidam-2 Lake & 3.74 & $\mathrm{BDL}$ & 5540 & 11.3 & 3.17 & 53.5 & $\mathrm{BDL}$ & $\mathrm{BDL}$ & 31.5 \\
Gurvany-1 Lake & 2.98 & & 2430 & 26 & 2.62 & 32.0 & $\mathrm{BDL}$ & $\mathrm{BDL}$ & 30.5 \\
Shar Burdiin Lake & 6.91 & $\mathrm{BDL}$ & 38.6 & 3.93 & $\mathrm{BDL}$ & $\mathrm{BDL}$ & $\mathrm{BDL}$ & $\mathrm{BDL}$ & 2.88 \\
Gurvany-2 Lake & 16.9 & $\mathrm{BDL}$ & $\mathrm{BDL}$ & 11.5 & $\mathrm{BDL}$ & 1.75 & 0.92 & $\mathrm{BDL}$ & 8.88 \\
Tsaidam-1 Lake & $\mathrm{BDL}$ & $\mathrm{BDL}$ & $\mathrm{BDL}$ & 46.6 & $\mathrm{BDL}$ & 1.77 & 3.11 & $\mathrm{BDL}$ & 17.1 \\
Tsaidam-2-pore water & $\mathrm{BDL}$ & 43.4 & $\mathrm{BDL}$ & 19.1 & $\mathrm{BDL}$ & 5.24 & 1.53 & $\mathrm{BDL}$ & 3.91 \\
Gurvany-1 pore water & $\mathrm{BDL}$ & 13.8 & $\mathrm{BDL}$ & 12.8 & $\mathrm{BDL}$ & 8.32 & 1.46 & $\mathrm{BDL}$ & 22.3 \\
Shar Burdiin pore water & 14.2 & 2.92 & $\mathrm{BDL}$ & 14.3 & $\mathrm{BDL}$ & 1.06 & 0.93 & $\mathrm{BDL}$ & 7.61 \\
Gurvany-2 pore water & & & & & & & & & $\mu \mathrm{mol} / \mathrm{mol}$ \\
Tsaidam-1 pore waters & & & & & &
\end{tabular}


Table 15: Continued trace metals for lake water and lake pore water samples.

\begin{tabular}{lccccccccc}
\hline Samples & Se & $\mathbf{R b}$ & $\mathbf{S r}$ & $\mathbf{C o}$ & $\mathbf{B a}$ & $\mathbf{P b}$ & $\mathbf{T h}$ & $\mathbf{U}$ & $\begin{array}{c}\text { U from } \\
\text { TIMS }\end{array}$ \\
& $\mu \mathrm{mol} / \mathrm{L}$ & $\mu \mathrm{mol} / \mathrm{L}$ & $\mu \mathrm{mol} / \mathrm{L}$ & $\mu \mathrm{mol} / \mathrm{L}$ & $\mu \mathrm{mol} / \mathrm{L}$ & $\mu \mathrm{mol} / \mathrm{L}$ & $\mu \mathrm{mol} / \mathrm{L}$ & $\mu \mathrm{mol} / \mathrm{L}$ & $\mu \mathrm{mol} / \mathrm{L}$ \\
\hline Tsaidam-2 Lake & BDL & 0.05 & 13.1 & 3.81 & 0.43 & 0.02 & BDL & 0.59 & 0.562 \\
Gurvany-1 Lake & 0.13 & 0.01 & 1.80 & 3.18 & 0.38 & BDL & BDL & 1.14 & \\
Shar Burdiin Lake & 0.37 & BDL & 9.22 & 14.1 & 2.93 & BDL & 0.54 & 62.5 & 52.9 \\
Gurvany-2 Lake & BDL & 0.01 & 5.26 & 13.3 & 4.04 & BDL & 0.55 & 42.7 & \\
Tsaidam-1 Lake & 0.02 & 0.03 & 3.29 & 1.44 & 0.26 & 0.03 & BDL & 0.24 & \\
\hline Tsaidam-2-pore water & 0.25 & 0.23 & 4.47 & 18.3 & 0.57 & BDL & BDL & 4.44 & \\
Gurvany-1 pore water & 1.25 & BDL & BDL & 8.38 & 2.88 & BDL & BDL & 11.2 & \\
Shar Burdiin pore water & BDL & BDL & 3.34 & 1.66 & 1.42 & BDL & BDL & 8.61 & \\
Gurvany-2 pore water & BDL & BDL & 2.12 & 6.31 & 4.74 & 0.45 & 0.4 & 23.8 & \\
Tsaidam-1 pore waters & BDL & 0.23 & 1.57 & 3.34 & 2.58 & 0.09 & BDL & 0.99 & \\
\hline
\end{tabular}


Table 16: $\delta^{234} \mathrm{U}$ and ${ }^{238} \mathrm{U} /{ }^{235} \mathrm{U}$ for Shar Burdiin Well and Lake and Tsaidam-2 Well 1 and Lake with measurement uncertainties. External precision for $\delta{ }^{234} \mathrm{U}$ was calculated by Musgrove et al. (2001) for the instrument. Measurement uncertainty for ${ }^{238} \mathrm{U} /{ }^{235} \mathrm{U}$ is from the analytical method used.

\begin{tabular}{|c|c|c|c|c|}
\hline Sample & $\delta^{234} U$ & $\begin{array}{c}\text { External Precision } \\
(2 \sigma) \\
\pm\end{array}$ & $\underset{{ }^{238} \mathbf{U} /{ }^{235} \mathbf{U}}{\text { Mean }}$ & $\begin{array}{c}\text { Measurement } \\
\text { Uncertainty } \\
\pm\end{array}$ \\
\hline $\begin{array}{l}\text { Tsaidam-2 Well } \\
1\end{array}$ & 303.6 & 3.20 & 136.4 & 0.23 \\
\hline Tsaidam-2 Lake & 1530 & 3.20 & 134.18 & 0.29 \\
\hline $\begin{array}{l}\text { Shar Burdiin } \\
\text { Well } \\
\text { Shar Burdiin } \\
\end{array}$ & $\begin{array}{l}837.6 \\
858.5\end{array}$ & 3.20 & $\begin{array}{l}137.2 \\
1362\end{array}$ & 0.4 \\
\hline SRM 112-A & -37.7 & 3.20 & 136.43 & 0.23 \\
\hline
\end{tabular}

Table 17: Sediment analyses from XRD and ESEM analyses.

\begin{tabular}{|c|c|c|}
\hline Sample & XRD Minerals found in lake sediments & ESEM Elements \\
\hline Tsaidam-2 Lake & $\begin{array}{l}\text { Quartz, Calcite, Muscovite, Orthoclase, } \\
\text { Dolomite, Aluminum, Montmorillonite }\end{array}$ & \\
\hline Gurvany-1 Lake & Quartz, Calcite, Albite, Anhydrite, Muscovite & $\begin{array}{c}\mathrm{Na}, \mathrm{Si}, \mathrm{O}, \mathrm{C}, \mathrm{Mg}, \\
\mathrm{Al}\end{array}$ \\
\hline Shar Burdiin Lake & Quartz, Phlogopite, Orthoclase, Albite & $\begin{array}{c}\mathrm{Si}, \mathrm{O}, \mathrm{Na}, \mathrm{Al}, \mathrm{Ca}, \\
\mathrm{K}\end{array}$ \\
\hline Gurvany-2 Lake & $\begin{array}{l}\text { Quartz, Calcite, Albite, Montmorillonite, } \\
\text { Orthoclase, Aluminum }\end{array}$ & \\
\hline $\begin{array}{l}\text { Gurvany-2 Lake salt } \\
\text { crust }\end{array}$ & & $\mathrm{Na}, \mathrm{C}, \mathrm{O}, \mathrm{S}$ \\
\hline Tsaidam-1 Lake & $\begin{array}{c}\text { Dolomite, Quartz, Albite, Aluminum, Muscovite, } \\
\text { Montmorillonite }\end{array}$ & \\
\hline
\end{tabular}


Table 18: Major cations for sediment digest procedure.

\begin{tabular}{lccccccc}
\hline Sample & $\begin{array}{c}\mathbf{B} \\
\mathrm{mmol} / \mathrm{Kg}\end{array}$ & $\begin{array}{c}\mathbf{N a} \\
\mathrm{mmol} / \mathrm{Kg}\end{array}$ & $\begin{array}{c}\mathbf{M g} \\
\mathrm{mmol} / \mathrm{Kg}\end{array}$ & $\begin{array}{c}\mathbf{S i} \\
\mathrm{mmol} / \mathrm{Kg}\end{array}$ & $\begin{array}{c}\mathbf{P} \\
\mathrm{mmol} / \mathrm{Kg}\end{array}$ & $\begin{array}{c}\mathbf{K} \\
\mathrm{mmol} / \mathrm{Kg}\end{array}$ & $\begin{array}{c}\mathbf{C a} \\
\mathrm{mmol} / \mathrm{Kg}\end{array}$ \\
\hline Gurvany-1 sed digest & 9.34 & 1130 & 126 & 32.9 & 5.76 & 31.6 & 309 \\
Shar Burdiin sed digest & $\mathrm{BDL}$ & 1030 & 864 & 47 & 15.1 & 138 & 898 \\
Tsaidam-1 sed digest & 33.9 & 1540 & 4530 & 105 & 56.9 & 420 & 3260 \\
Tsaidam-2-sed digest A & 22.8 & 1520 & 2700 & 112 & 40.7 & 256 & 3370 \\
Tsaidam-2-sed digest B & 27.6 & 1950 & 3620 & 143 & 53.7 & 325 & 4470 \\
Gurvany-2 sed digest A & 13.3 & 2690 & 1140 & 131 & 33.9 & 210 & 1140 \\
Gurvany-2 sed digest B & 19.3 & 2540 & 1180 & 114 & 32.9 & 261 & 1120 \\
Procedure Blank & $\mathrm{BDL}$ & $\mathrm{BDL}$ & $\mathrm{BDL}$ & 0.01 & $\mathrm{BDL}$ & $\mathrm{BDL}$ & 0.01 \\
\hline
\end{tabular}


Table 19: Trace metals for sediment digest procedure.

\begin{tabular}{lccccccccc}
\hline Sample & $\mathbf{L i}$ & $\mathbf{A l}$ & $\mathbf{P}$ & $\mathbf{V}$ & $\mathbf{M n}$ & $\mathbf{F e - T}$ & $\mathbf{C u}$ & $\mathbf{Z n}$ & $\begin{array}{c}\text { AsT } \\
\mu \mathrm{mol} / \mathrm{Kg}\end{array}$ \\
& $\mu \mathrm{mol} / \mathrm{Kg}$ & $\mu \mathrm{mol} / \mathrm{Kg}$ & $\mu \mathrm{mol} / \mathrm{Kg}$ & $\mu \mathrm{mol} / \mathrm{Kg}$ & $\mu \mathrm{mol} / \mathrm{Kg}$ & $\mu \mathrm{mol} / \mathrm{Kg}$ & $\mu \mathrm{mol} / \mathrm{Kg}$ & $\mu \mathrm{mol} / \mathrm{Kg}$ \\
\hline Gurvany-1 sed digest & 324 & 131000 & 4870 & 229 & 3250 & 57300 & $\mathrm{BDL}$ & 52.0 & $\mathrm{BDL}$ \\
Shar Burdiin sed digest & 376 & 781000 & 10200 & 697 & 8070 & 277000 & 230 & 769 & $\mathrm{BDL}$ \\
Tsaidam-1 sed digest & 372 & 1880000 & 37200 & 2190 & 26200 & 713000 & 454 & 2000 & 302 \\
Tsaidam-2-sed digest & & & & & & & & & \\
A & 491 & 1230000 & 25900 & 1450 & 18400 & 469000 & 401 & 1360 & 406 \\
Tsaidam-2-sed digest B & 541 & 1550000 & 34600 & 1820 & 24200 & 610000 & 500 & 1890 & 436 \\
Gurvany-2 sed digest A & 405 & 1190000 & 22000 & 739 & 12500 & 434000 & 298 & 1140 & 107 \\
Gurvany-2 sed digest B & 401 & 1640000 & 21800 & 1100 & 12700 & 544000 & 347 & 1480 & 96 \\
Procedure Blank & 0.01 & 0.58 & 1.89 & $\mathrm{BDL}$ & 0.01 & 0.53 & 0.01 & 0.07 & $\mathrm{BDL}$ \\
\hline
\end{tabular}


Table 20: Continued trace metals for sediment digest procedure.

\begin{tabular}{|c|c|c|c|c|c|c|c|c|}
\hline Sample & $\begin{array}{c}\text { Se } \\
\mu \mathrm{mol} / \mathrm{Kg} \\
\end{array}$ & $\begin{array}{c}\mathbf{R b} \\
\mu \mathrm{mol} / \mathrm{Kg}\end{array}$ & $\begin{array}{c}\mathbf{S r} \\
\mu \mathrm{mol} / \mathrm{Kg}\end{array}$ & $\begin{array}{c}\text { Co } \\
\mu \mathrm{mol} / \mathrm{Kg}\end{array}$ & $\begin{array}{c}\text { Ba } \\
\mu \mathrm{mol} / \mathrm{Kg}\end{array}$ & $\begin{array}{c}\mathbf{P b} \\
\mu \mathrm{mol} / \mathrm{Kg}\end{array}$ & $\begin{array}{c}\text { Th } \\
\mu \mathrm{mol} / \mathrm{Kg}\end{array}$ & $\begin{array}{c}\mathbf{U} \\
\mu \mathrm{mol} / \mathrm{Kg}\end{array}$ \\
\hline Gurvany-1 sed digest & BDL & BDL & 986 & BDL & 234 & BDL & 37 & 9.04 \\
\hline Shar Burdiin sed digest & BDL & 273 & 4430 & BDL & 1330 & 58.3 & 169 & 24.8 \\
\hline $\begin{array}{l}\text { Tsaidam-1 sed digest } \\
\text { Tsaidam-2-sed digest }\end{array}$ & BDL & 568 & 20100 & 343 & 2300 & 115 & 253 & 9.58 \\
\hline A & BDL & 379 & 16200 & 482 & 1610 & 106 & 200 & 29 \\
\hline $\begin{array}{l}\text { Tsaidam-2-sed digest B } \\
\text { Gurvany-2 sed digest }\end{array}$ & BDL & 455 & 21000 & 502 & 2060 & 130 & 261 & 32.2 \\
\hline A & BDL & 405 & 5670 & 439 & 1790 & 95 & 231 & 42.2 \\
\hline Gurvany-2 sed digest B & BDL & 526 & 5460 & 411 & 1810 & 97 & 227 & 41 \\
\hline Procedure Blank & BDL & BDL & $\mathrm{BDL}$ & $\mathrm{BDL}$ & 0.01 & $\mathrm{BDL}$ & $\mathrm{BDL}$ & BDL \\
\hline
\end{tabular}


Table 21: Saturation indices calculated using PHREEQC for select minerals in all investigated lakes.

\begin{tabular}{|c|c|c|c|c|c|c|}
\hline Mineral & Formula & $\begin{array}{c}\text { Tsaidam-2 } \\
\text { Lake } \\
\text { SI } \\
\end{array}$ & $\begin{array}{c}\text { Tsaidam-1 } \\
\text { Lake } \\
\text { SI } \\
\end{array}$ & 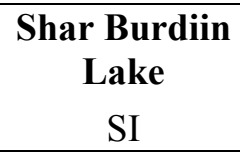 & $\begin{array}{c}\text { Gurvany-2 } \\
\text { Lake ** } \\
\text { SI } \\
\end{array}$ & $\begin{array}{c}\text { Gurvany-1 } \\
\text { Lake ** } \\
\text { SI } \\
\end{array}$ \\
\hline Halite & $\mathrm{NaCl}$ & -2.67 & -3.07 & -1.63 & -1.86 & -3.25 \\
\hline Calcite & $\mathrm{CaCO}_{3}$ & 0.86 & 0.24 & 0.04 & 0.04 & -0.11 \\
\hline Dolomite & $\mathrm{MgCO}_{3}$ & 2.93 & 2.03 & 2.54 & 2.4 & 2.13 \\
\hline Gypsum & $\mathrm{MgSO}_{4}$ & -1.94 & -2.91 & -4.2 & -4.26 & -3.54 \\
\hline Anhydrite & $\mathrm{MgSO}_{4}$ & -2.12 & -3.14 & -4.32 & -4.42 & -3.77 \\
\hline Sepiolite * & $\mathrm{Mg}_{2} \mathrm{Si}_{3} \mathrm{O}_{7.5} \mathrm{OH} \cdot 3 \mathrm{H}_{2} \mathrm{O}$ & -2.05 & -4.8 & -0.26 & & -2.19 \\
\hline Magnesite & $\mathrm{MgCO}_{3}$ & 1.18 & 0.97 & 1.6 & 1.5 & 1.42 \\
\hline Siderite * & $\mathrm{FeCO}_{3}$ & -3.97 & & -1.57 & -4.32 & -3.03 \\
\hline Strontianite * & $\mathrm{SrCO}_{3}$ & 0.27 & 0.04 & 1.1 & 0.96 & 0.25 \\
\hline Rhodochrosite* & $\mathrm{MnCO}_{3}$ & & -0.06 & 1.61 & 1.66 & 0.76 \\
\hline Hematite* & $\mathrm{Fe}_{2} \mathrm{O}_{3}$ & & & 19.22 & 18.65 & 18.31 \\
\hline Ferrihydrite & $\mathrm{Fe}(\mathrm{OH})_{3}$ & & & 2.48 & 2.35 & 2.31 \\
\hline Goethite & $\mathrm{FeOOH}$ & & & 7.08 & 6.81 & 6.65 \\
\hline Rutherfordine & $\mathrm{UO}_{2} \mathrm{CO}_{3}$ & -8.38 & -9.48 & -6.31 & -7.42 & -9.78 \\
\hline Carnotite & $\mathrm{KUO}_{2} \mathrm{VO}_{4}$ & -4.63 & -5.93 & -1.49 & -2.98 & -6.37 \\
\hline Tyuyamunite & $\mathrm{Ca}_{0.5} \mathrm{UO}_{2} \mathrm{VO}_{4}$ & -5.4 & -7.15 & -3.18 & -4.9 & -7.63 \\
\hline
\end{tabular}

*calculated using Minteq database without the Pizter equation

** Added $0.01 \mathrm{mmol} \mathrm{L}^{-1} \mathrm{Ca}$ as $\mathrm{Ca}$ in lake water is below detection limit. 
Table 22: Saturation indices for select minerals during the evaporation of Shar Burdiin Well.

\begin{tabular}{|c|c|c|c|c|c|c|c|}
\hline \multicolumn{2}{|l|}{ Shar Burdiin Well } & \multirow{2}{*}{$\begin{array}{c}\mathbf{0 \%} \\
\text { SI } \\
\end{array}$} & \multirow{2}{*}{$\begin{array}{c}\mathbf{5 0} \% \\
\text { SI } \\
\end{array}$} & \multirow{2}{*}{$\begin{array}{c}\mathbf{7 5} \% \\
\text { SI } \\
\end{array}$} & \multirow{2}{*}{$\begin{array}{c}\mathbf{8 0} \% \\
\text { SI }\end{array}$} & \multirow{2}{*}{$\begin{array}{c}\mathbf{9 0} \% \\
\text { SI }\end{array}$} & \multirow{2}{*}{$\begin{array}{c}99 \% \\
\text { SI }\end{array}$} \\
\hline Mineral & Formula & & & & & & \\
\hline Trona & $\mathrm{NaCO}_{3}$ & -11.94 & -10.56 & -9.21 & -8.79 & -7.50 & -3.49 \\
\hline Halite & $\mathrm{NaCl}$ & -6.44 & -5.87 & -5.30 & -5.12 & -4.57 & -2.70 \\
\hline Calcite & $\mathrm{CaCO}_{3}$ & 0.11 & 0.58 & 1.00 & 1.15 & 1.60 & 3.23 \\
\hline Dolomite & $\mathrm{MgCO}_{3}$ & 0.10 & 1.03 & 2.01 & 2.29 & 3.15 & 6.07 \\
\hline Gypsum & $\mathrm{CaSO}_{4} \cdot 2 \mathrm{H}_{2} \mathrm{O}$ & -1.96 & -1.53 & -1.30 & -1.16 & -0.76 & 0.69 \\
\hline Anhydrite & $\mathrm{CaSO}_{4}$ & -2.39 & -1.96 & -1.55 & -1.42 & -1.01 & 0.47 \\
\hline Sepiolite * & $\mathrm{Mg}_{2} \mathrm{Si}_{3} \mathrm{O}_{7.5} \mathrm{OH} \cdot 3 \mathrm{H}_{2} \mathrm{O}$ & -4.93 & -3.73 & -2.58 & -2.22 & -1.14 & 2.20 \\
\hline Magnesite & $\mathrm{MgCO}_{3}$ & -0.47 & 0.00 & 0.51 & 0.65 & 1.05 & 2.34 \\
\hline Siderite * & $\mathrm{FeCO}_{3}$ & -0.84 & -4.52 & -3.91 & -3.72 & -3.11 & -0.96 \\
\hline Strontianite $*$ & $\mathrm{SrCO}_{3}$ & -1.22 & -0.74 & -0.28 & -0.14 & 0.29 & 1.60 \\
\hline Rhodochrosite* & $\mathrm{MnCO}_{3}$ & -0.77 & -0.32 & 0.11 & 0.24 & 0.63 & 1.67 \\
\hline Hematite* & $\mathrm{Fe}_{2} \mathrm{O}_{3}$ & 12.7 & 16.83 & 17.39 & 17.57 & 18.11 & 19.81 \\
\hline Ferrihydrite & $\mathrm{Fe}(\mathrm{OH})_{3}$ & 0.3 & 2.36 & 2.64 & 2.73 & 3 & 3.82 \\
\hline Goethite & $\mathrm{FeO} \cdot \mathrm{OH}$ & 3.9 & 5.96 & 6.24 & 6.33 & 6.6 & 7.44 \\
\hline Montmorillonite & $(\mathrm{Na}, \mathrm{Ca})_{0.33}(\mathrm{Al}, \mathrm{Mg})_{2}\left(\mathrm{Si}_{4} \mathrm{O}_{10}\right)(\mathrm{OH})_{2} \cdot \mathrm{nH}_{2} \mathrm{O}$ & 8.33 & 10.52 & 12.33 & 12.91 & 14.73 & 21.45 \\
\hline Rutherfordine * & $\mathrm{UO}_{2} \mathrm{CO}_{3}$ & -5.72 & -5.92 & -6.28 & -6.41 & -6.83 & -6.07 \\
\hline Carnotite* & $\mathrm{KUO}_{2} \mathrm{VO}_{4}$ & -4.13 & -4.25 & -4.55 & -4.67 & -5.05 & -3.64 \\
\hline Tyuyamunite* & $\mathrm{Ca}_{0.5} \mathrm{UO}_{2} \mathrm{VO}_{4}$ & -3.88 & -4.18 & -4.65 & -4.82 & -5.38 & -4.57 \\
\hline
\end{tabular}

*calculated using Minteq database without the Pizter equation

** Added $0.01 \mathrm{mmol} \mathrm{L-1} \mathrm{Ca}$ as $\mathrm{Ca}$ in lake water is below detection limit. 
Table 23: Saturation indices of selected minerals during evaporation of Shar Burdiin Lake.

\begin{tabular}{|c|c|c|c|c|c|c|c|}
\hline $\begin{array}{c}\text { Shar Burdiin } \\
\text { Lake }\end{array}$ & & $0 \%$ & $25 \%$ & $50 \%$ & $75 \%$ & $80 \%$ & $90 \%$ \\
\hline Mineral & Formula & SI & SI & SI & SI & SI & SI \\
\hline Trona & $\mathrm{NaCO}_{3}$ & -1.61 & -1.12 & -0.36 & 1.29 & 1.98 & 4.82 \\
\hline Halite & $\mathrm{NaCl}$ & -1.63 & -1.36 & -0.91 & 0.13 & 0.6 & 2.96 \\
\hline Calcite & $\mathrm{CaCO}_{3}$ & 0.04 & 0.17 & 0.39 & 0.8 & 0.92 & 1.24 \\
\hline Dolomite & $\mathrm{MgCO}_{3}$ & 2.54 & 2.83 & 3.29 & 4.16 & 4.41 & 5.04 \\
\hline Gypsum & $\mathrm{CaSO}_{4} \cdot 2 \mathrm{H}_{2} \mathrm{O}$ & -4.2 & -4.1 & -3.96 & -3.89 & -4.03 & -5.88 \\
\hline Anhydrite & $\mathrm{CaSO}_{4}$ & -4.32 & -4.2 & -4.01 & -3.74 & -3.73 & -4.36 \\
\hline Sepiolite * & $\mathrm{Mg}_{2} \mathrm{Si}_{3} \mathrm{O}_{7.5} \mathrm{OH} \cdot 3 \mathrm{H}_{2} \mathrm{O}$ & -0.26 & 0.31 & 1.13 & 2.41 & 2.69 & 3.4 \\
\hline Magnesite & $\mathrm{MgCO}_{3}$ & 1.6 & 1.74 & 1.99 & 2.45 & 2.58 & 2.89 \\
\hline Siderite * & $\mathrm{FeCO}_{3}$ & -1.57 & -1.4 & -0.94 & 0.27 & 0.72 & 1.23 \\
\hline Strontianite * & $\mathrm{SrCO}_{3}$ & 1.1 & 1.17 & 1.23 & 1.24 & 1.19 & 0.81 \\
\hline Rhodochrosite* & $\mathrm{MnCO}_{3}$ & 1.61 & 1.65 & 1.64 & 1.39 & 1.2 & -0.04 \\
\hline Hematite* & $\mathrm{Fe}_{2} \mathrm{O}_{3}$ & 19.22 & 19.73 & 20.54 & 22.3 & 23.03 & 24.88 \\
\hline Ferrihydrite & $\mathrm{Fe}(\mathrm{OH})_{3}$ & 2.48 & 2.73 & 3.1 & 3.89 & 4.19 & 4.75 \\
\hline Goethite & $\mathrm{FeO} \cdot \mathrm{OH}$ & 7.08 & 7.33 & 7.72 & 8.57 & 8.92 & 9.72 \\
\hline Rutherfordine & $\mathrm{UO}_{2} \mathrm{CO}_{3}$ & -6.31 & -4.91 & -3.18 & -0.62 & 0.59 & 2.56 \\
\hline Carnotite* & $\mathrm{KUO}_{2} \mathrm{VO}_{4}$ & -1.49 & 0.36 & 2.9 & 6.77 & 8.2 & 10.54 \\
\hline Tyuyamunite* & $\mathrm{Ca}_{0.5} \mathrm{UO}_{2} \mathrm{VO}_{4}$ & -3.18 & -1.86 & 0.68 & 4.56 & 5.98 & 8.08 \\
\hline
\end{tabular}

*calculated using Minteq database without the Pizter equation

** Added $0.01 \mathrm{mmol} \mathrm{L-1} \mathrm{Ca}$ as $\mathrm{Ca}$ in lake water is below detection limit. 
Table 24: Correlation coefficient matrix for selected parameters for the 6 groundwater sample sites. Correlation coeffiecients were calculated using AquaChem. Values closer to one are more correlated, and negative values indicate a negative correlation.

\begin{tabular}{|c|c|c|c|c|c|c|c|c|c|}
\hline $\begin{array}{l}\text { Correlat } \\
\text { coefficien } \\
6 \text { ground } \\
\end{array}$ & sam & & & & & & & & \\
\hline & pH & $\mathbf{K}$ & $\mathrm{Ca}$ & Mg & $\mathrm{Fe}$ & $\mathrm{Sr}$ & $\mathrm{Cl}$ & $\mathbf{U}$ & ${ }^{87} \mathrm{Sr} /{ }^{86} \mathrm{Sr}$ \\
\hline pH & 1 & 0.373 & -0.347 & -0.387 & -0.9 & -0.279 & -0.77 & 0.596 & -0.107 \\
\hline K & & 1 & -0.135 & -0.222 & 0.779 & -0.019 & 0.049 & -0.342 & -0.087 \\
\hline $\mathrm{Ca}$ & & & 1 & 0.932 & -0.212 & 0.874 & 0.618 & -0.486 & 0.087 \\
\hline Mg & & & & 1 & -0.111 & 0.936 & 0.705 & -0.303 & 0.215 \\
\hline $\mathbf{F e}$ & & & & & 1 & -0.022 & 0.656 & -0.501 & 0.613 \\
\hline $\mathrm{Sr}$ & & & & & & 1 & 0.728 & -0.273 & 0.478 \\
\hline Cl & & & & & & & 1 & -0.637 & 0.359 \\
\hline $\mathbf{U}$ & & & & & & & & 1 & 0.322 \\
\hline${ }^{87} \mathrm{Sr} /{ }^{86} \mathrm{Sr}$ & & & & & & & & & 1 \\
\hline
\end{tabular}


Table 25: Correlation coefficient matrix for selected parameters for the five lake water sample sites. Correlation coeffiecients were calculated using AquaChem (version 3.7). Values closer to one are more correlated, and negative values indicate a negative correlation.

\begin{tabular}{|c|c|c|c|c|c|c|c|c|c|}
\hline \multicolumn{10}{|c|}{$\begin{array}{l}\text { Correlation coefficient } \\
5 \text { lake samples }\end{array}$} \\
\hline & pH & $\mathbf{K}$ & $\mathrm{Cl}$ & $\mathbf{N a}$ & Mg & $\mathrm{Fe}$ & $\mathrm{Sr}$ & $\mathbf{U}$ & ${ }^{87} \mathrm{Sr} /{ }^{86} \mathrm{Sr}$ \\
\hline pH & 1.00 & 0.27 & 0.30 & 0.49 & -0.62 & 0.49 & -0.50 & 0.51 & 0.39 \\
\hline K & & 1.00 & 0.97 & 0.87 & -0.14 & 0.50 & 0.45 & 0.92 & 0.88 \\
\hline Cl & & & 1.00 & 0.95 & -0.14 & 0.30 & 0.45 & 0.96 & 0.96 \\
\hline $\mathrm{Na}$ & & & & 1.00 & -0.34 & 0.03 & 0.22 & 0.99 & 0.99 \\
\hline Mg & & & & & 1.00 & 0.90 & 0.81 & -0.37 & -0.26 \\
\hline $\mathrm{Fe}$ & & & & & & 1.00 & 0.45 & 0.23 & 0.00 \\
\hline $\mathrm{Sr}$ & & & & & & & 1.00 & 0.21 & 0.31 \\
\hline $\mathbf{U}$ & & & & & & & & 1.00 & 0.98 \\
\hline${ }^{87} \mathrm{Sr} /$ & & & & & & & & & 1.00 \\
\hline
\end{tabular}




\section{FIGURES}

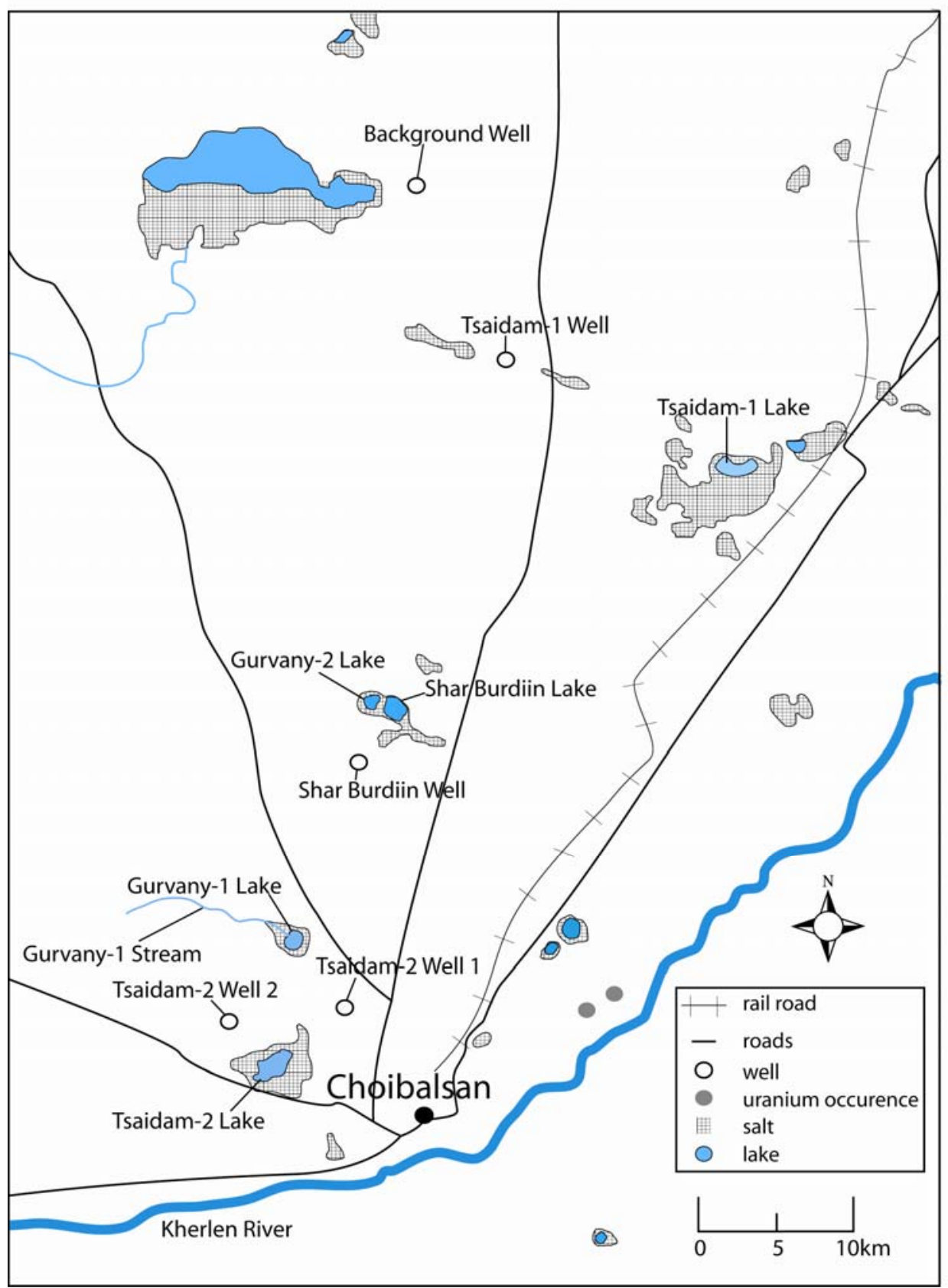

Figure 1: Map of field site in eastern Mongolia. 


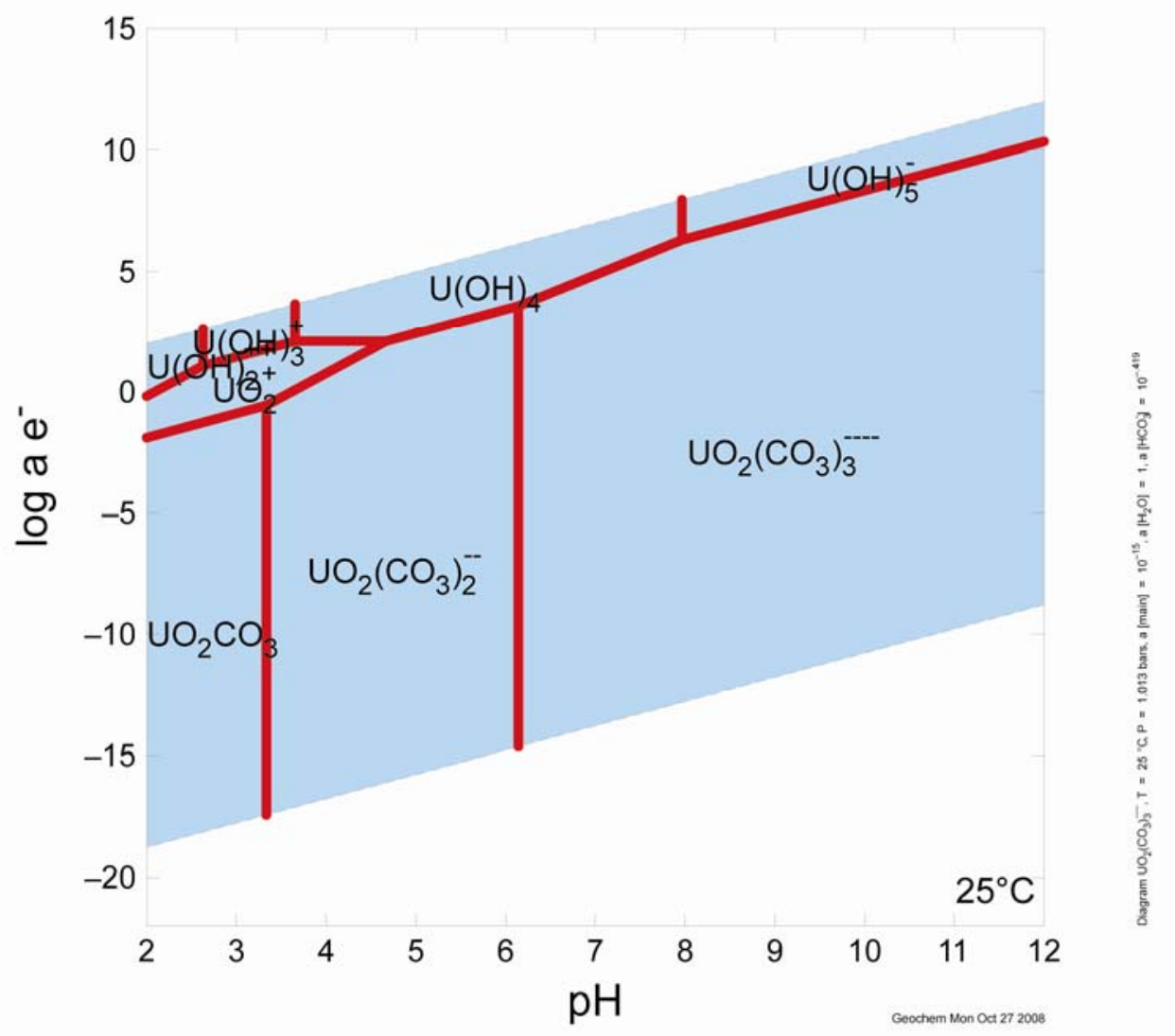

Figure 2: Uranium speciation diagram using activities of $\left[\mathrm{UO}_{2}\left(\mathrm{CO}_{3}\right)_{3}{ }^{-4}\right]=10^{-15}$ and $\left[\mathrm{HCO}_{3}{ }^{-}\right]=10^{-0.419}$ calculated for Shar Burdiin Lake. The diagram shows log activities on the $y$-axis and $\mathrm{pH}$ on the $\mathrm{x}$-axis. Diagram was created using Geochemist's Workbench ${ }^{\circledR}$. 


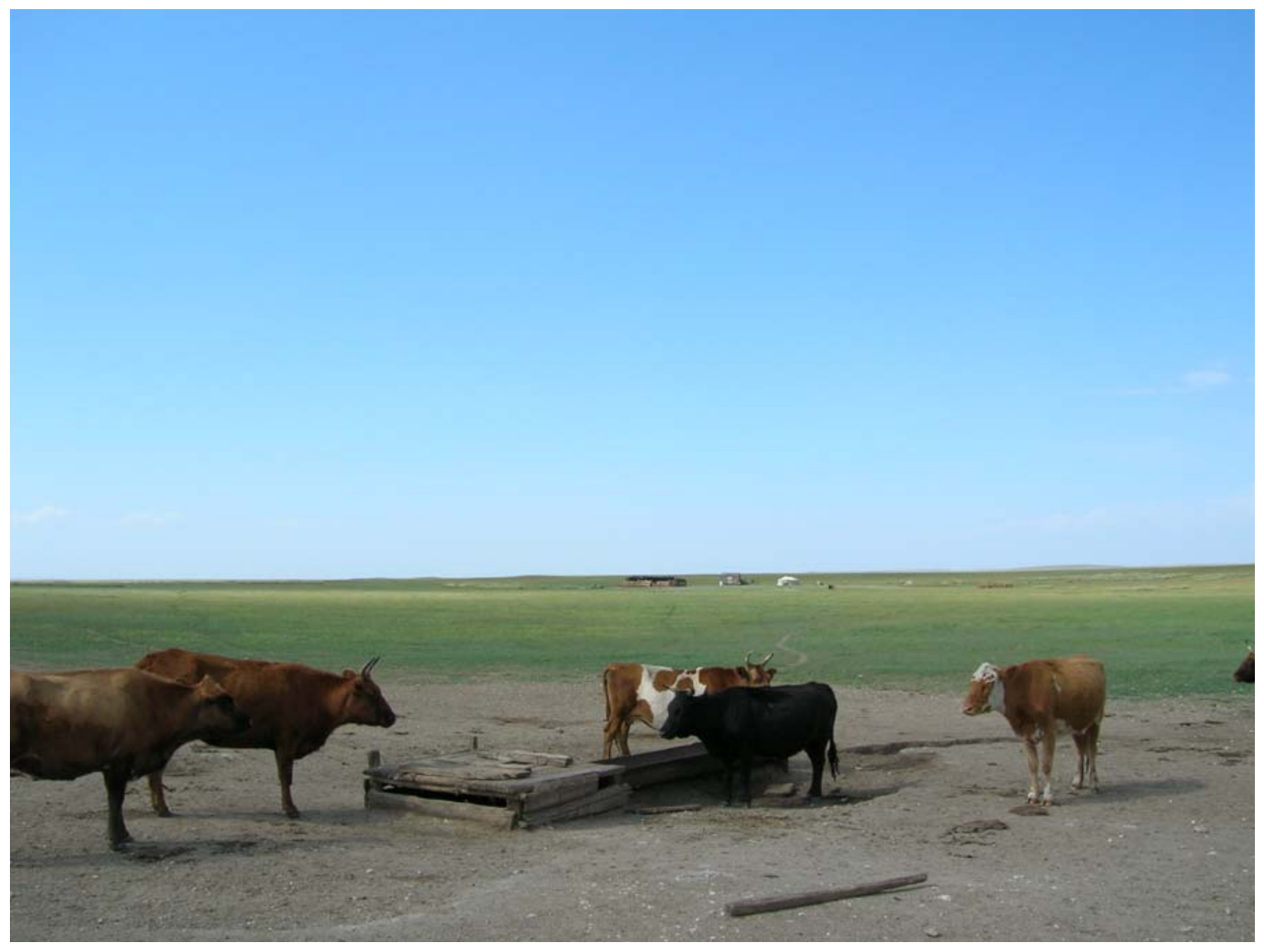

Figure 3: Shar Burdiin Well. 


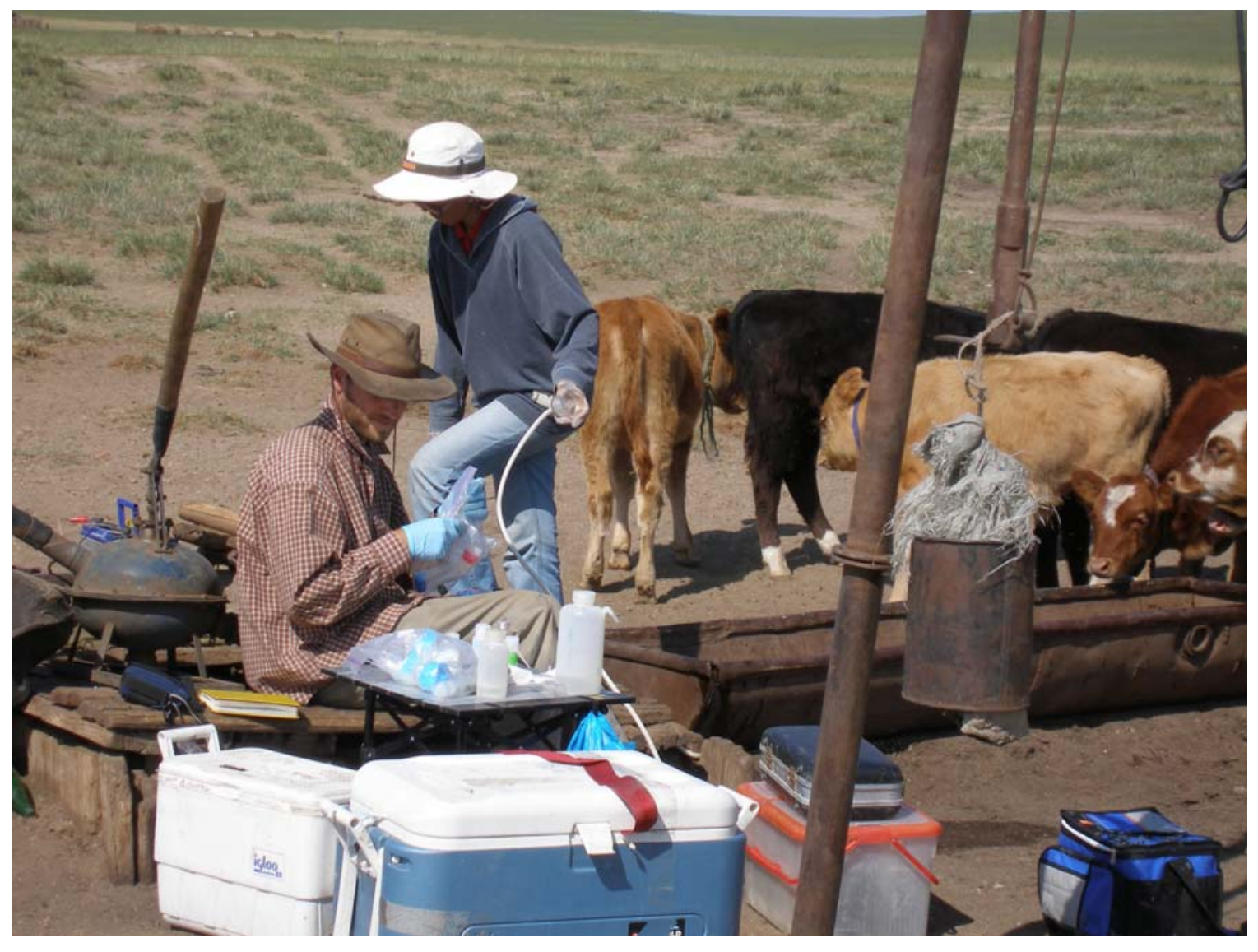

Figure 4: Field sampling at Tsiadam-1 Well. 


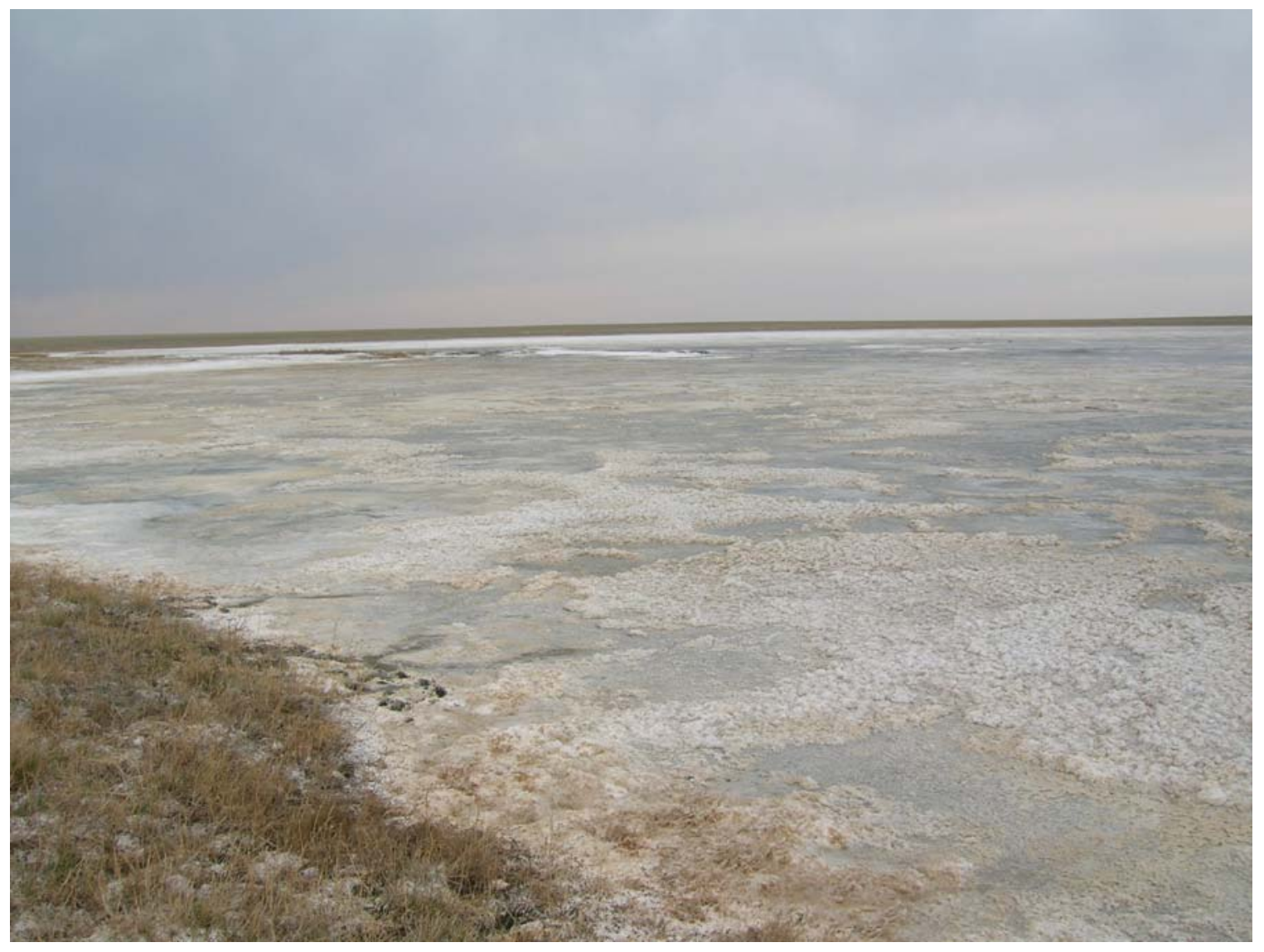

Figure 5: Shar Burdiin Lake during May, 2006 sampling trip. 


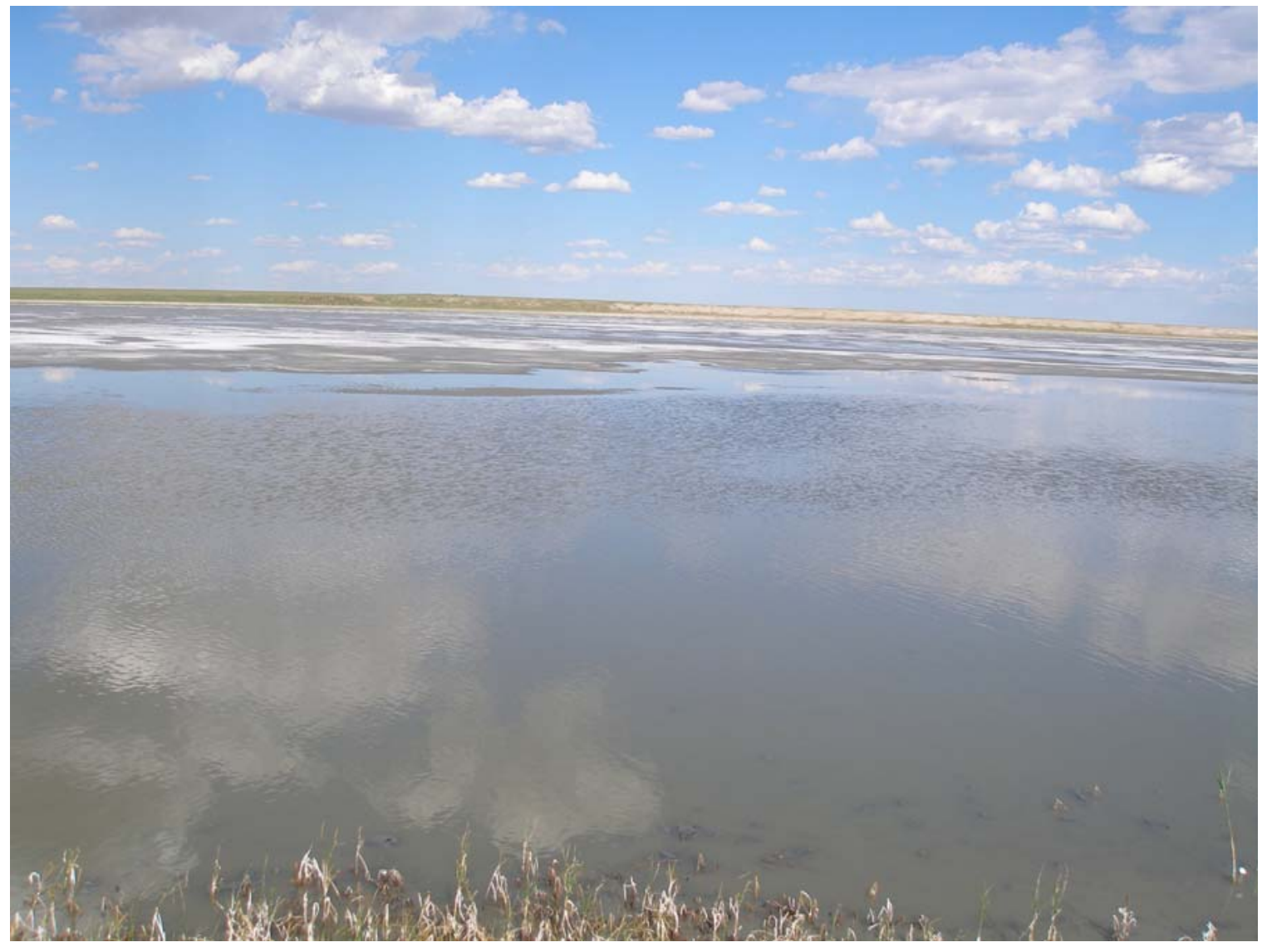

Figure 6: Shar Burdiin Lake during August,2006 sampling trip. 


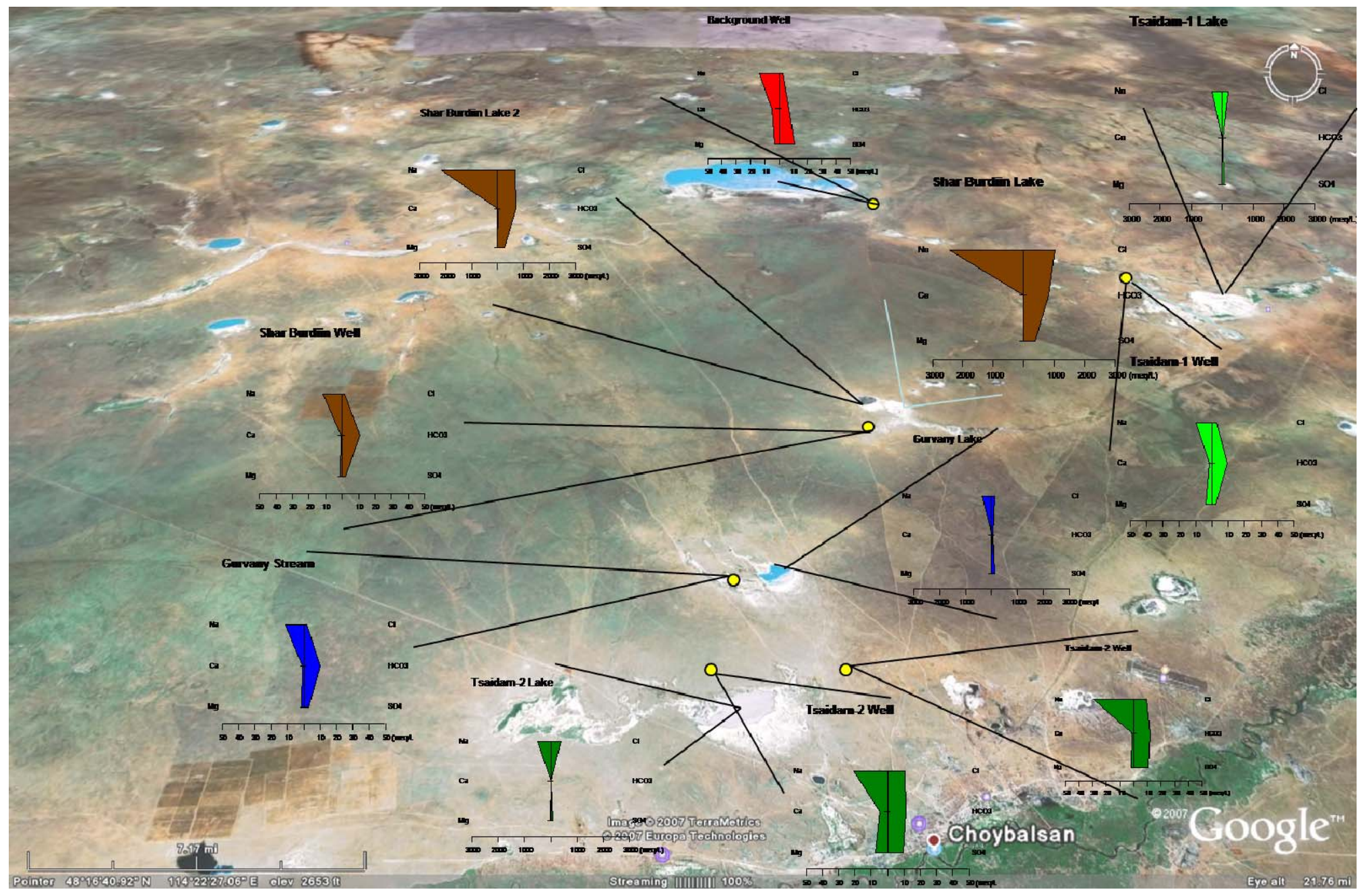

Figure 7: Stiff diagrams for each well and lake. Note that the scale for lakes is $0-3000 \mathrm{meq} / \mathrm{L}$ while well sites are $0-50 \mathrm{meq} / \mathrm{L}$. 


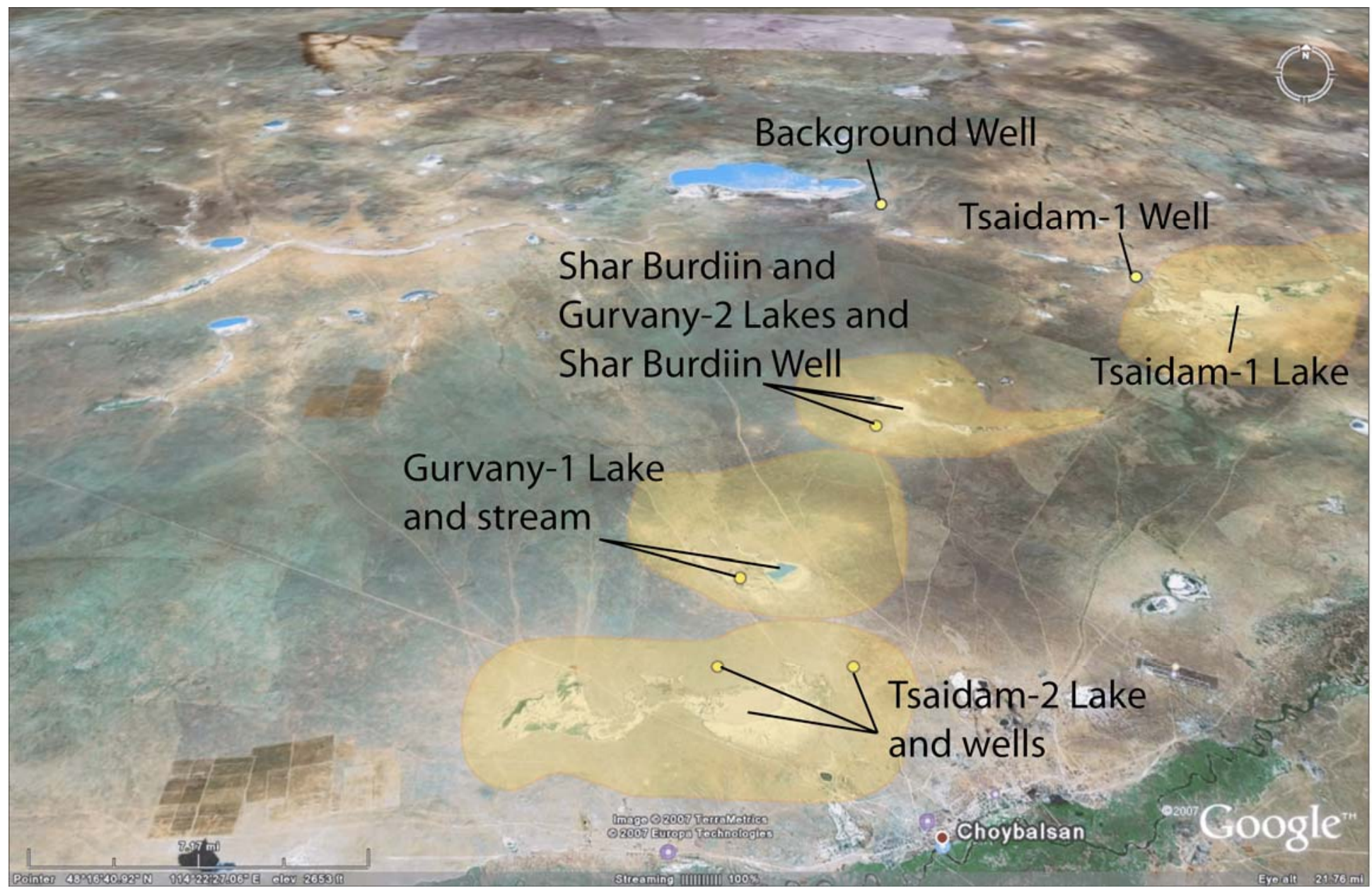

Figure 8: Catchment area for lakes shown in yellow with locations of groundwater and lake samples. 


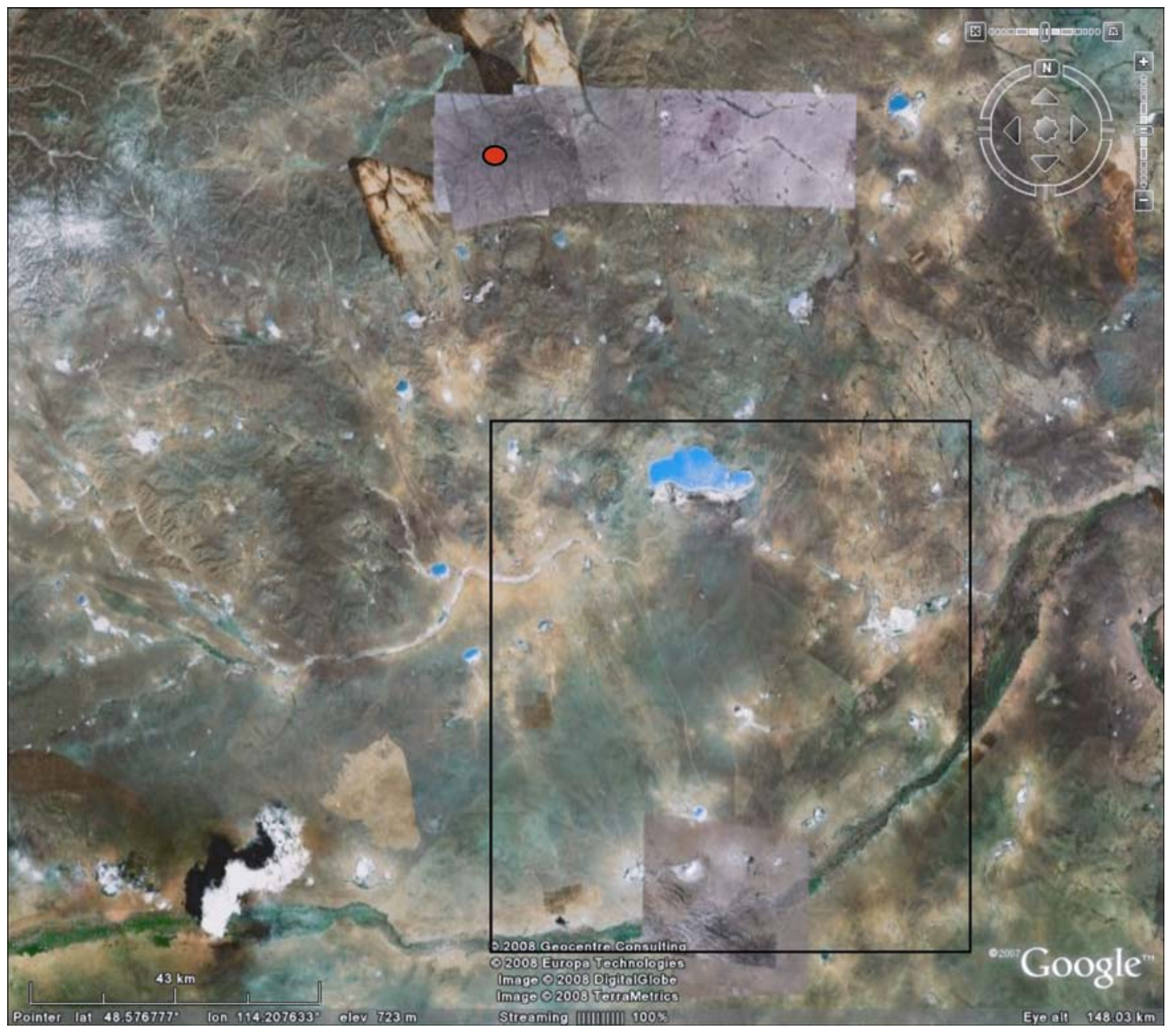

Figure 9: The investigated area is within in the black box. The approximate location of active $U$ mining is shown by the red dot. 


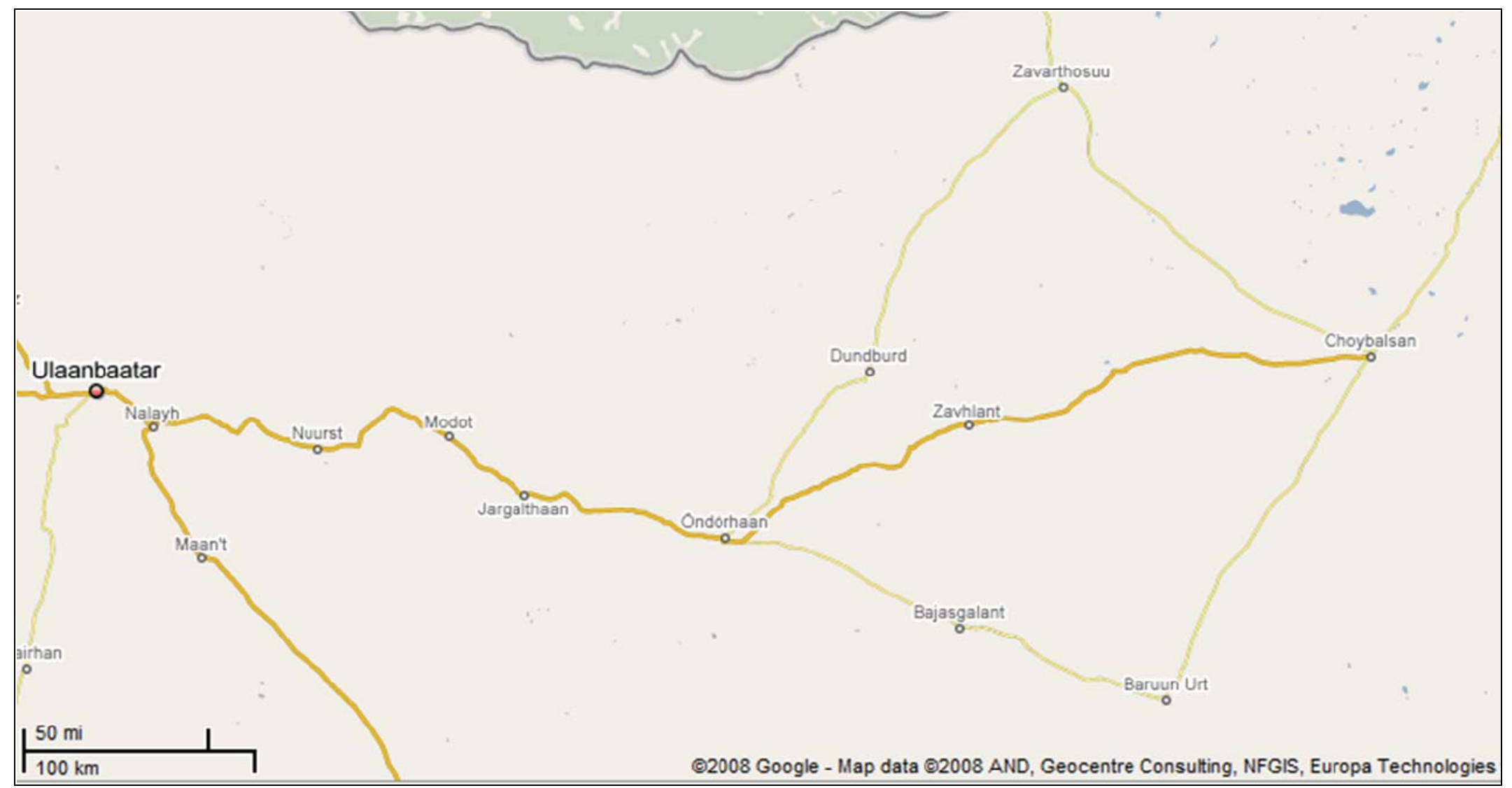

Figure 10: Choibalsan (spelled Choybalsan here) is located approximately $500 \mathrm{~km}$ east of Ulaanbaatar. 


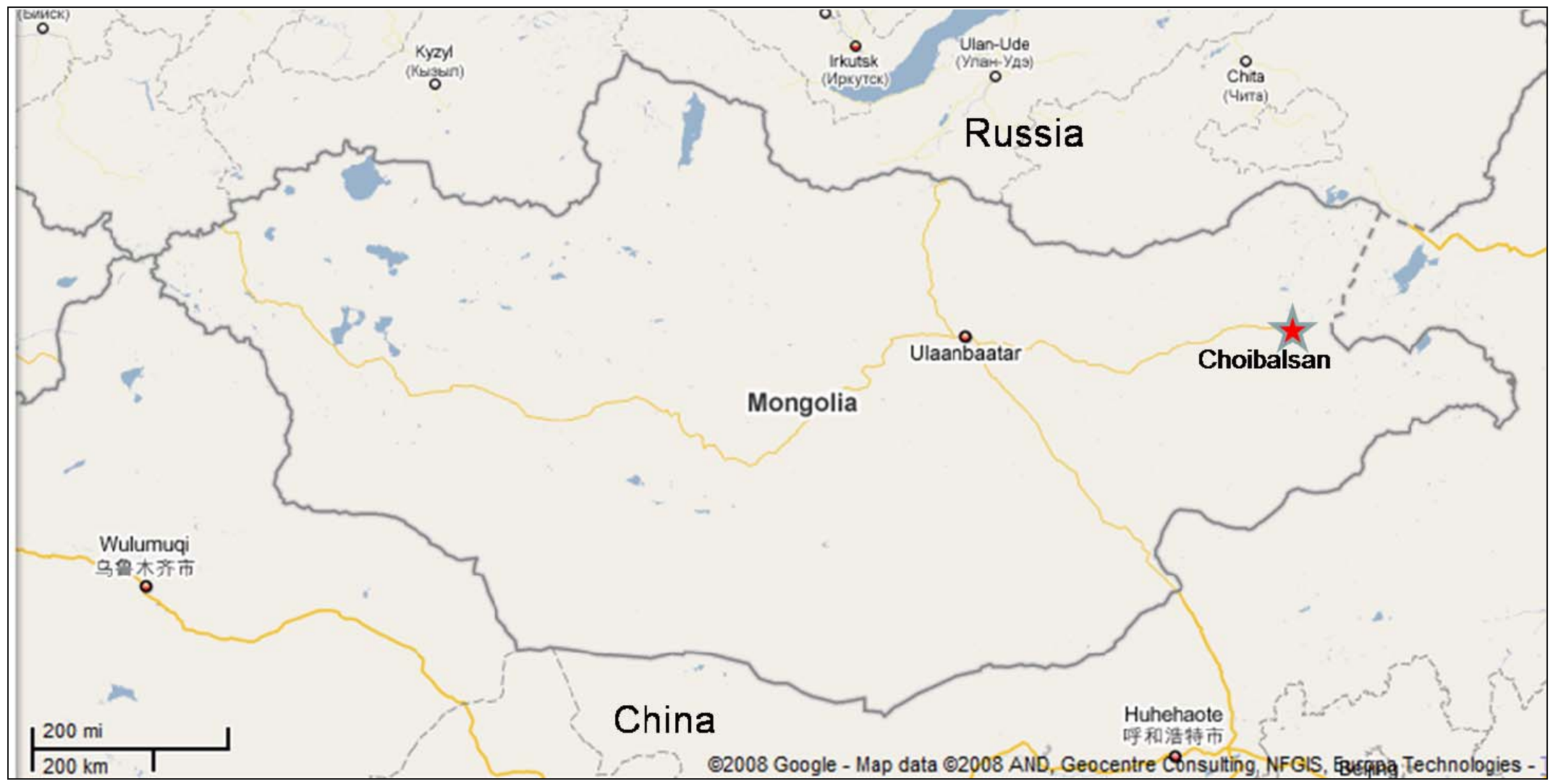

Figure 11: Map of Mongolia. The location of the investigated area near Choibalsan is shown with the red star. 


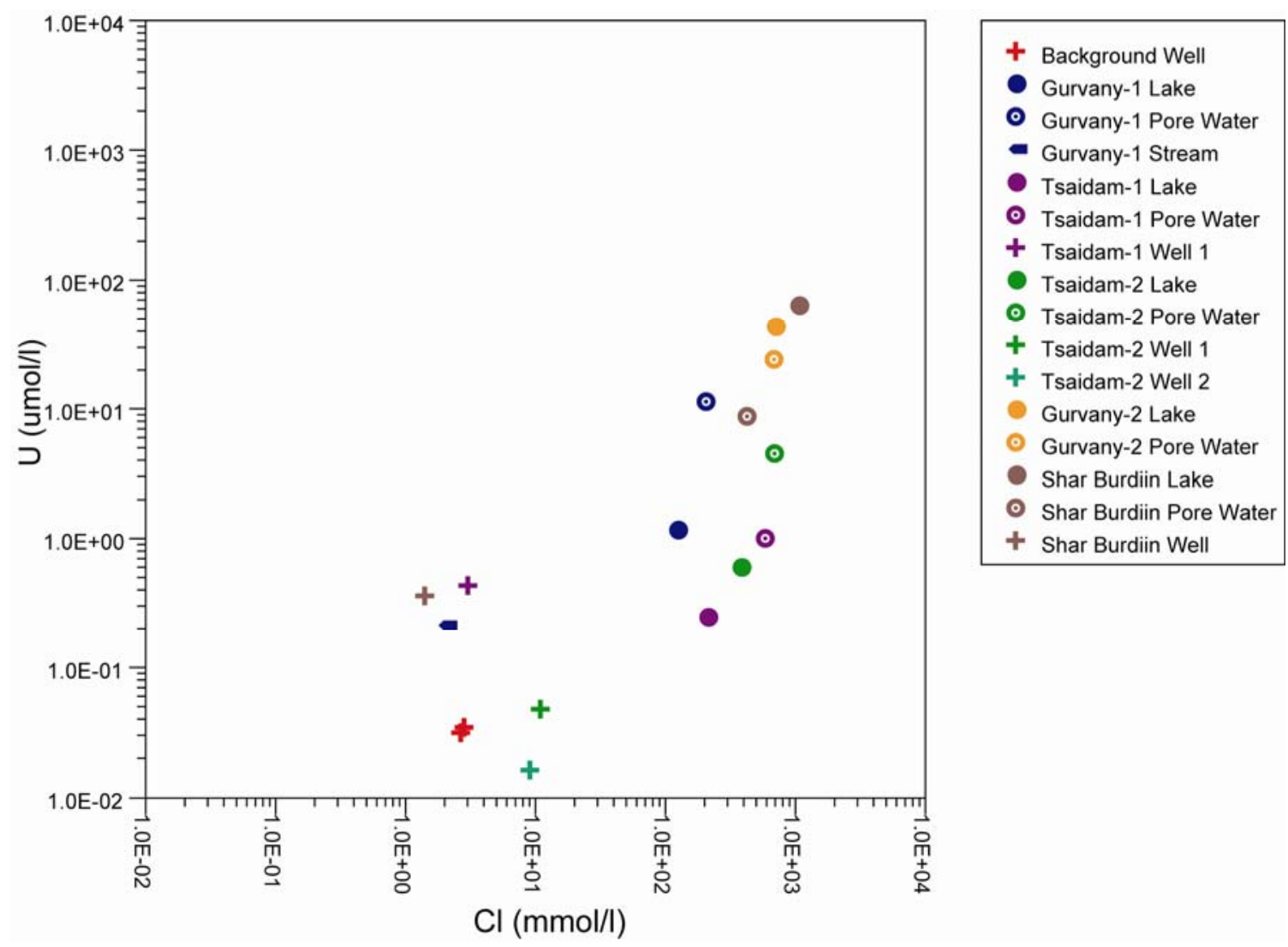

Figure 12: Uranium versus chloride for groundwater, lake water, and pore water samples. 


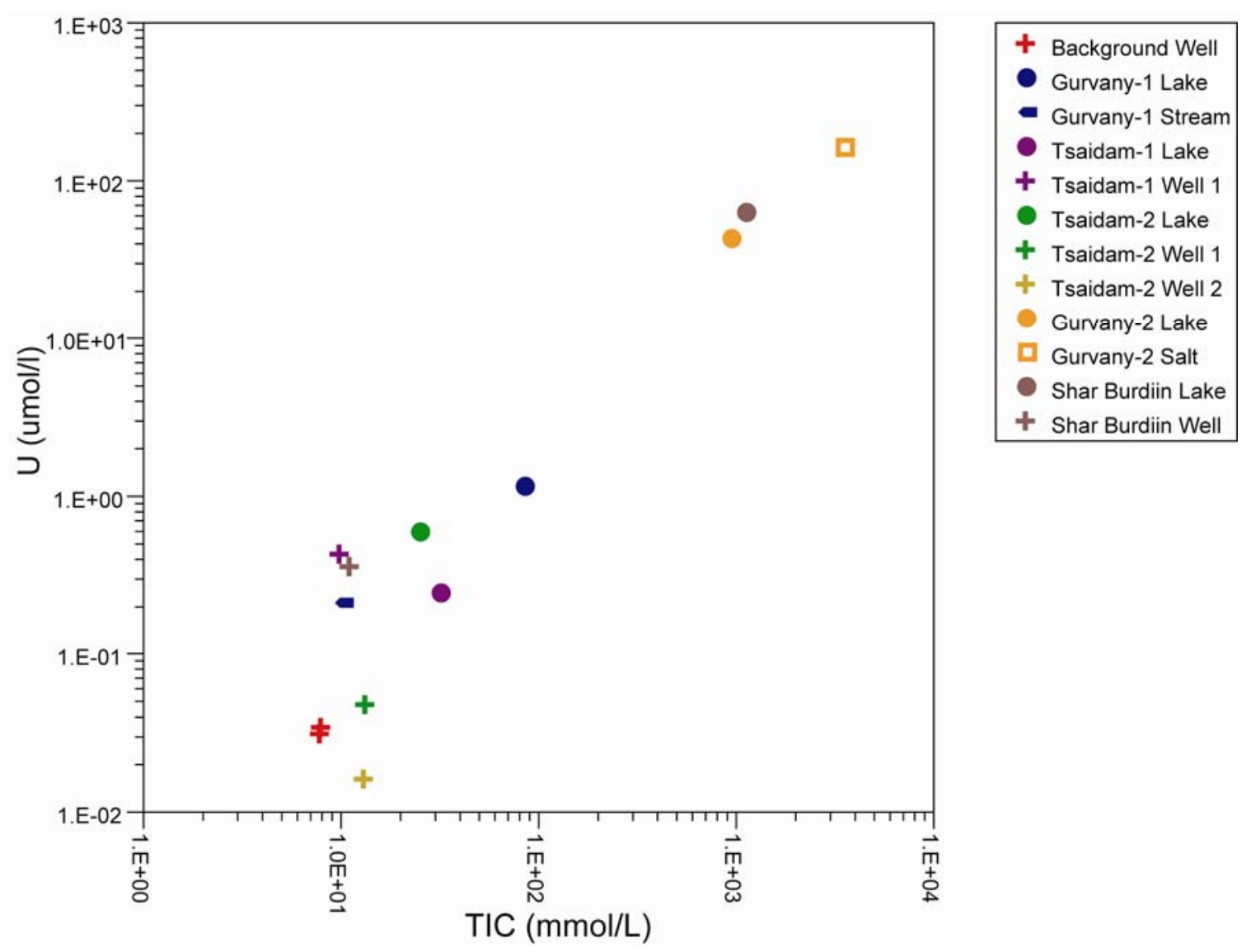

Figure 13: Uranium concentrations versus total inorganic carbon for all well and lake samples and for the dissolved salt (per kg) from the shore of Gurvany-2 Lake. 


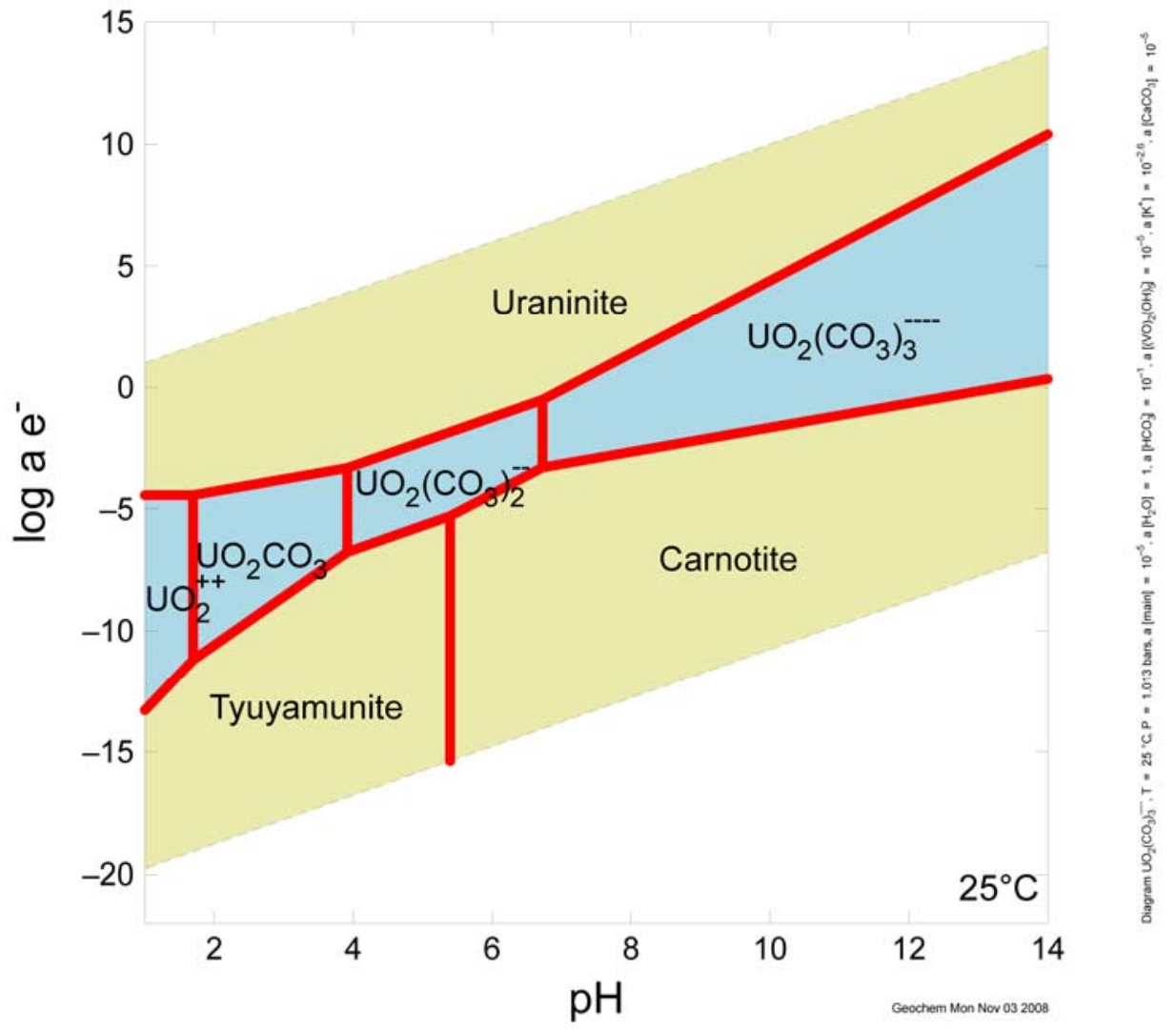

Figure 14: Uranium speciation with $\left[\mathrm{UO}_{2}\left(\mathrm{CO}_{3}\right)_{3}{ }^{-4}\right]=10^{-5},\left[\mathrm{HCO}_{3}{ }^{-}\right]=0.1$, $\left[(\mathrm{VO})_{2}(\mathrm{OH})_{5}\right]=10^{-5},\left[\mathrm{~K}^{+}\right]=10^{-2.6},\left[\mathrm{CaCO}_{3}\right]=10^{-5}$. The diagram shows log activity on the $\mathrm{y}$-axis and $\mathrm{pH}$ on the $\mathrm{x}$-axis. Diagram was created using Geochemist's Workbench ${ }^{\circledR}$. 


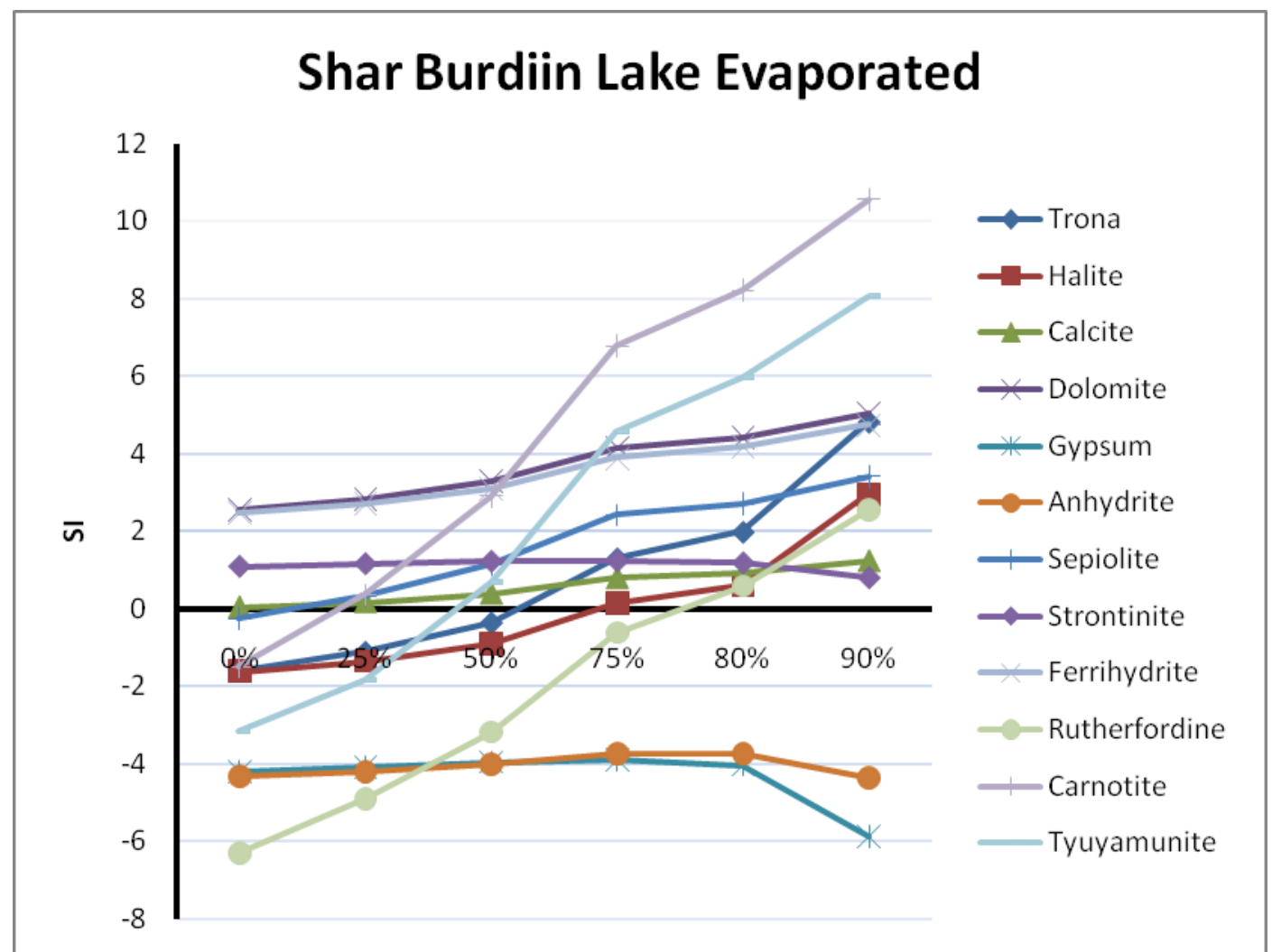

Figure 15: Selected mineral SI values calculated in PHREEQC for Shar Burdiin Lake during evaporation. 


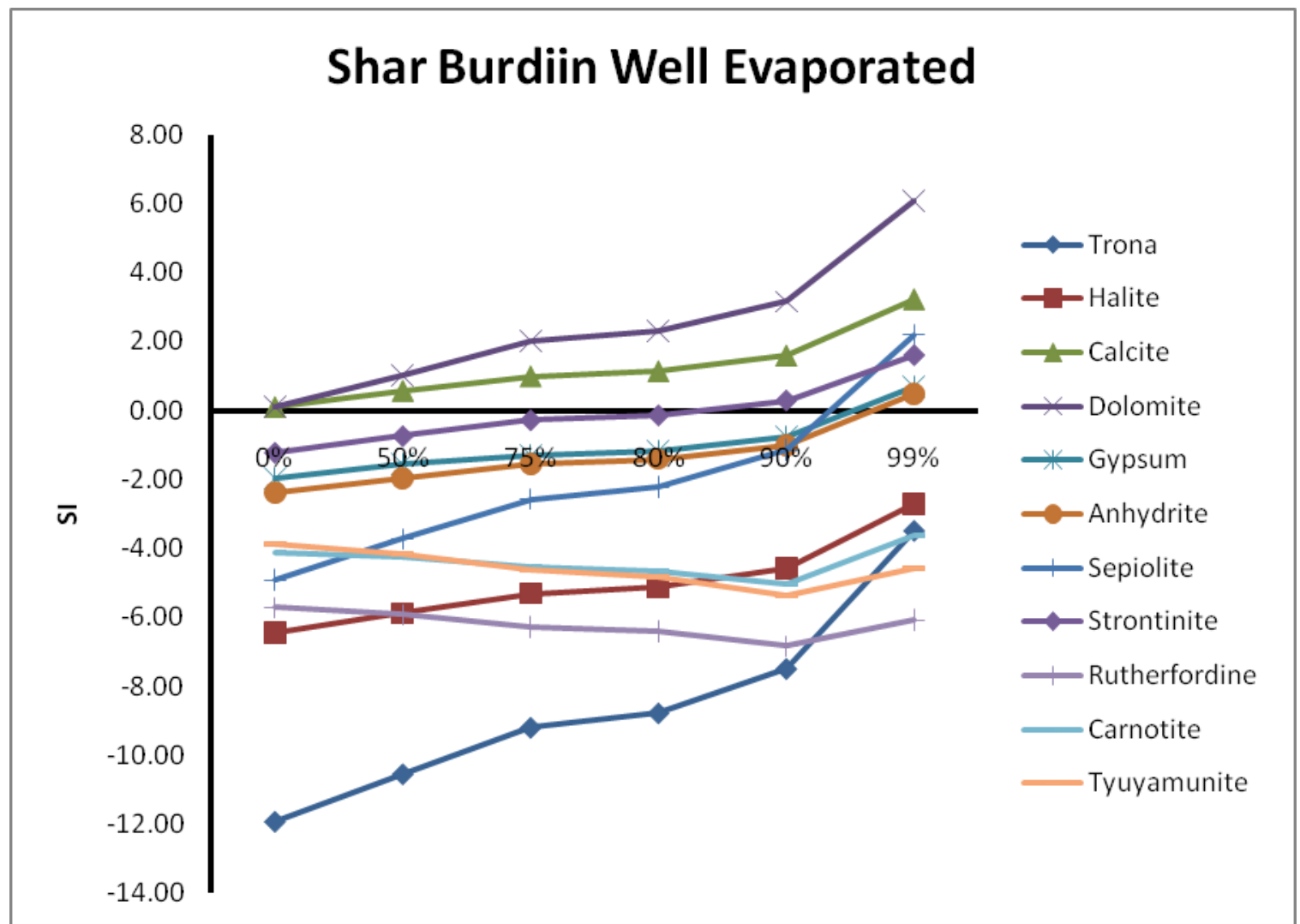

Figure 16: Selected mineral SI values calculated in PHREEQC for Shar Burdiin Well during evaporation. 


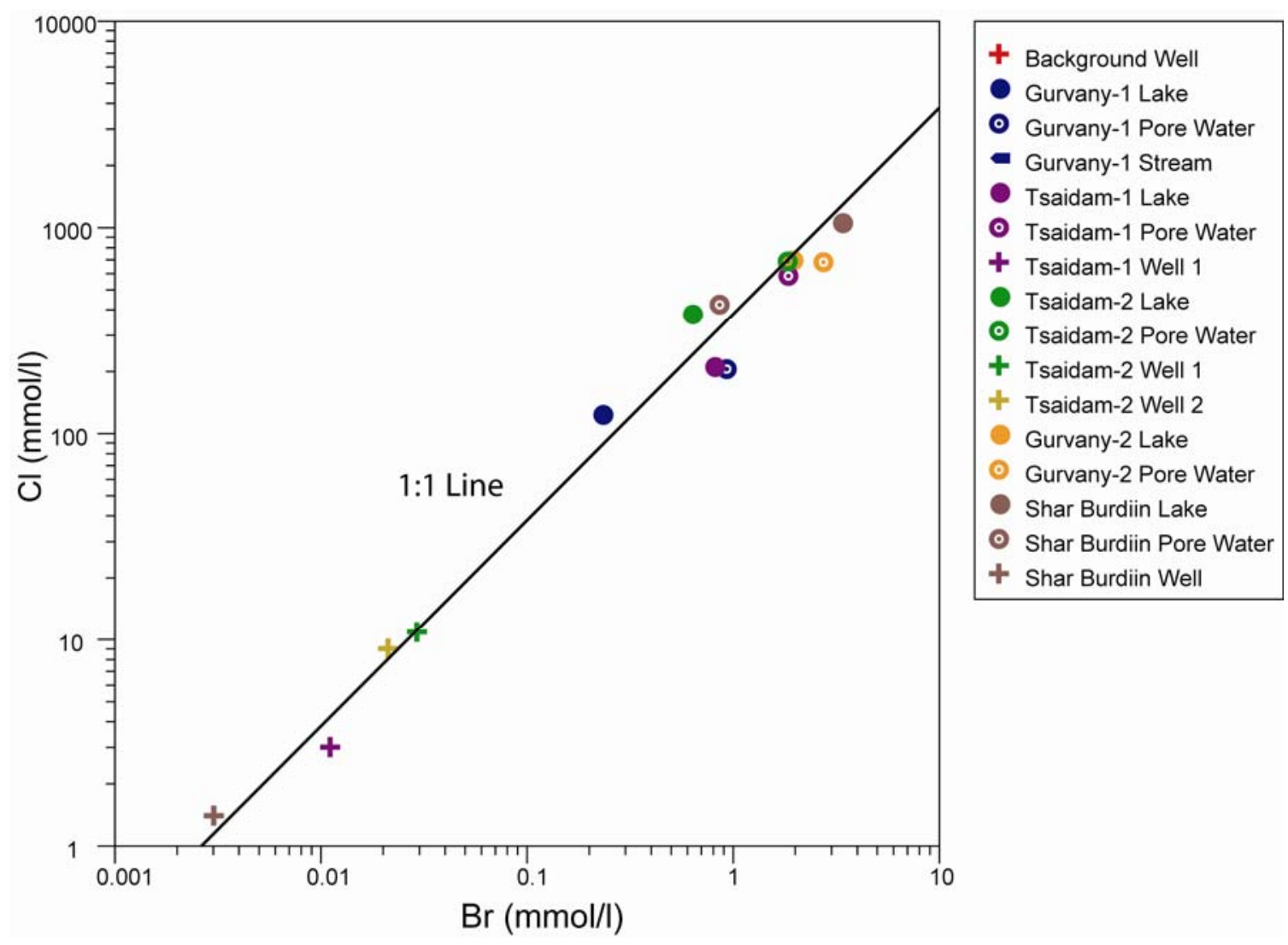

Figure 17: Chloride versus bromide for all wells, lakes and pore waters 


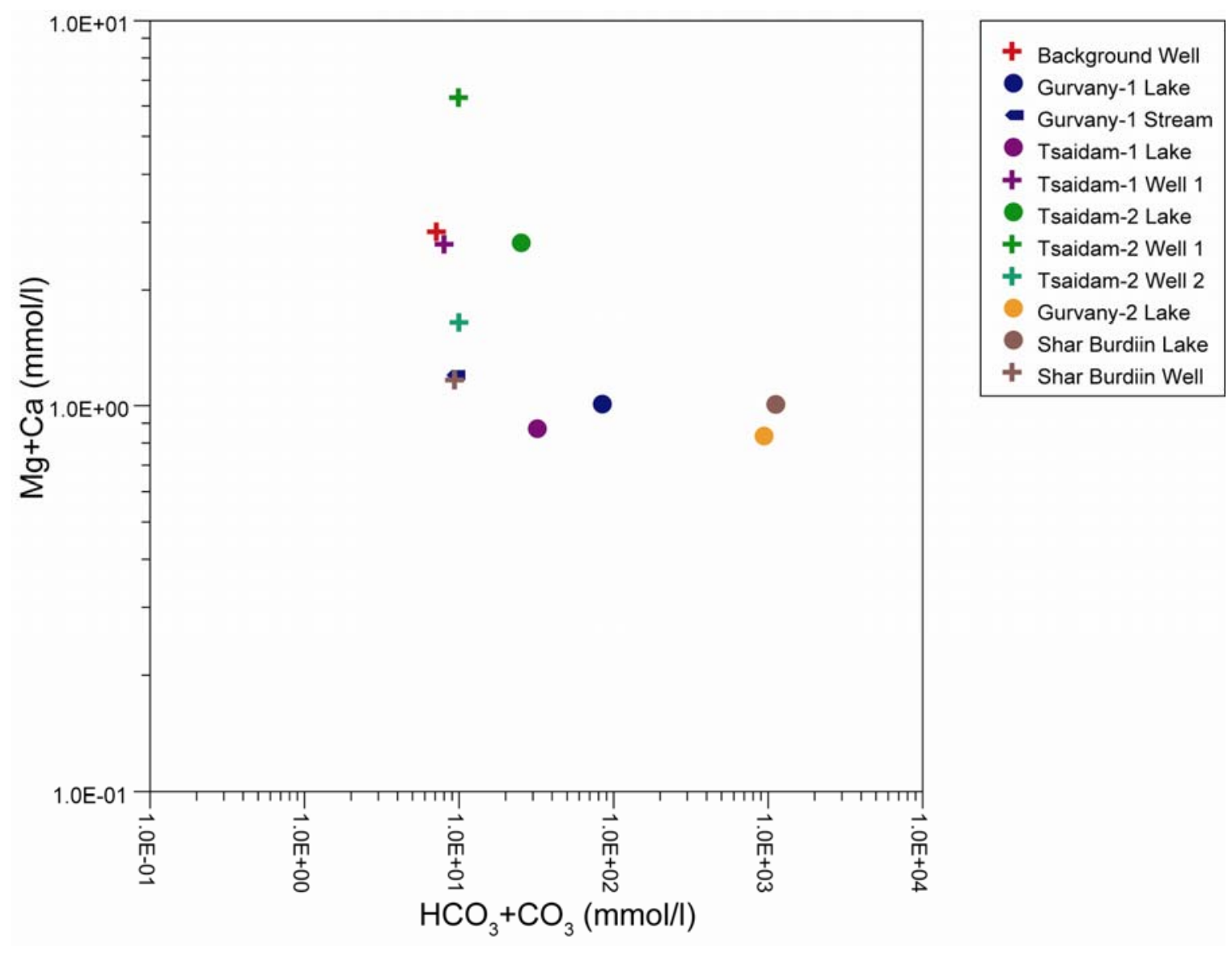

Figure 18: $\mathrm{Mg}+\mathrm{Ca}$ versus $\mathrm{HCO}_{3}+\mathrm{CO}_{3}$ for all well and lake samples. 


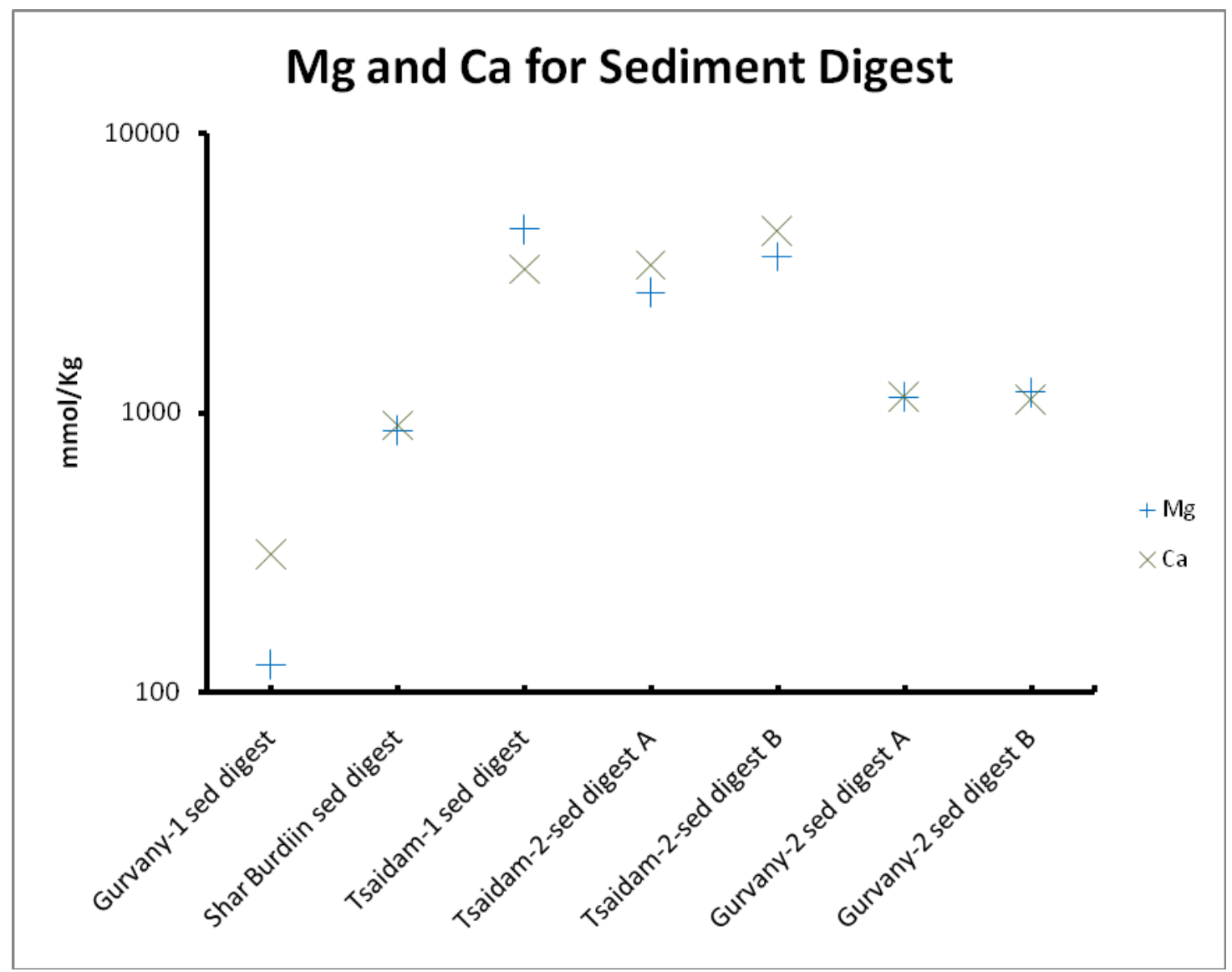

Figure 19: Calcium and magnesium derived from the sediment digestion procedure. 


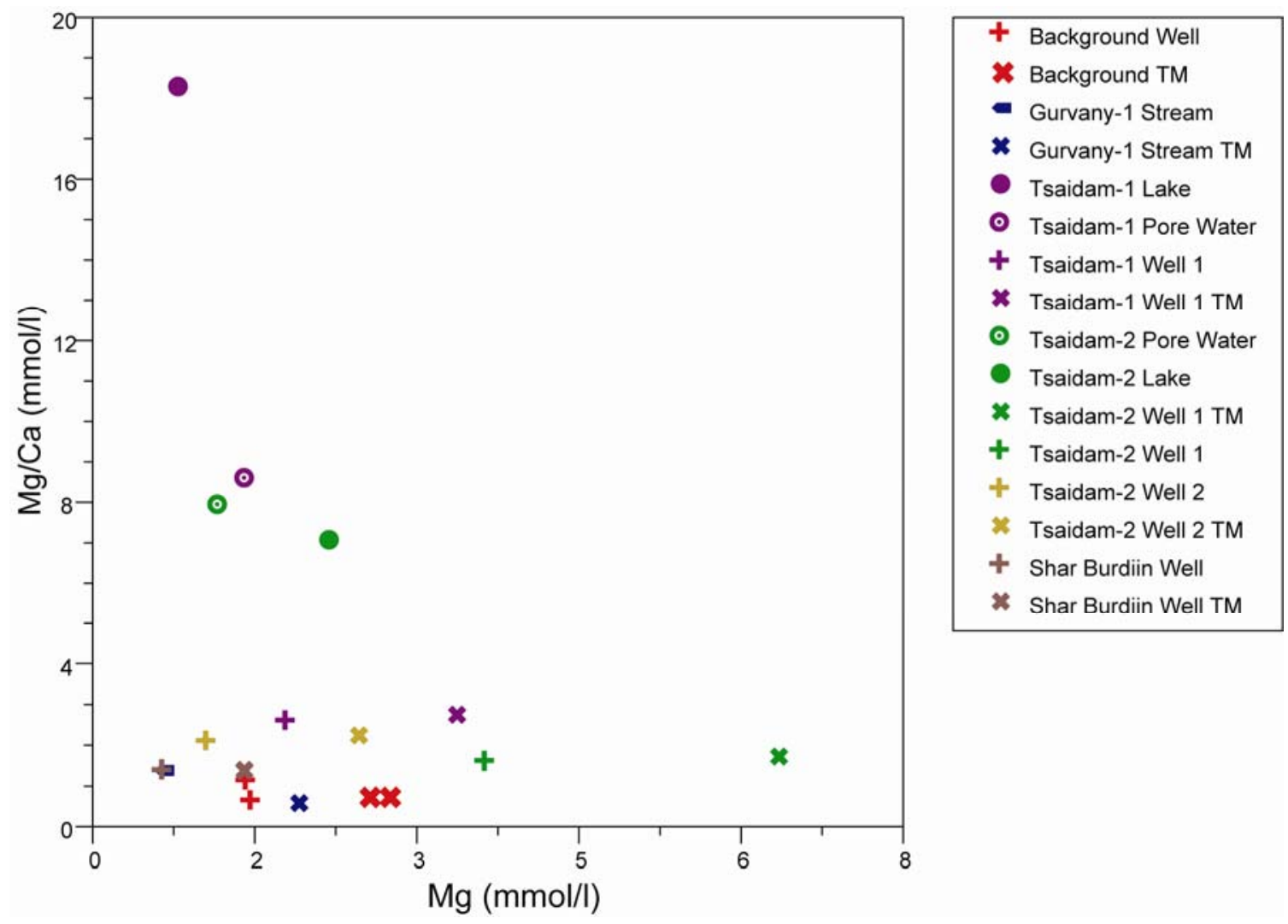

Figure 20: $\mathrm{Mg} / \mathrm{Ca}$ versus $\mathrm{Mg}$ for wells, total metal, and lake water samples. 


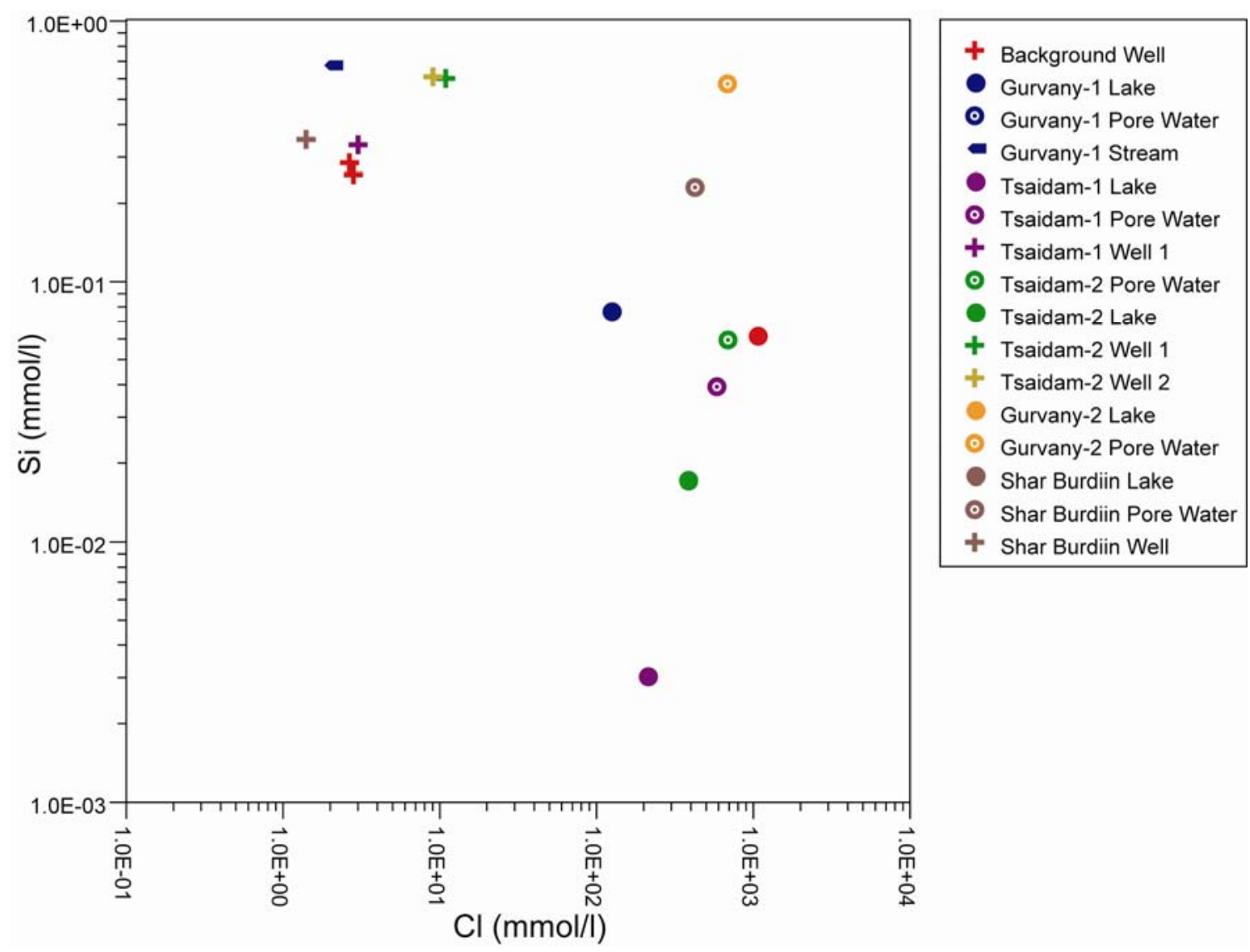

Figure 21: $\mathrm{Si}$ versus $\mathrm{Cl}$ for wells, lakes, and pore water samples. 


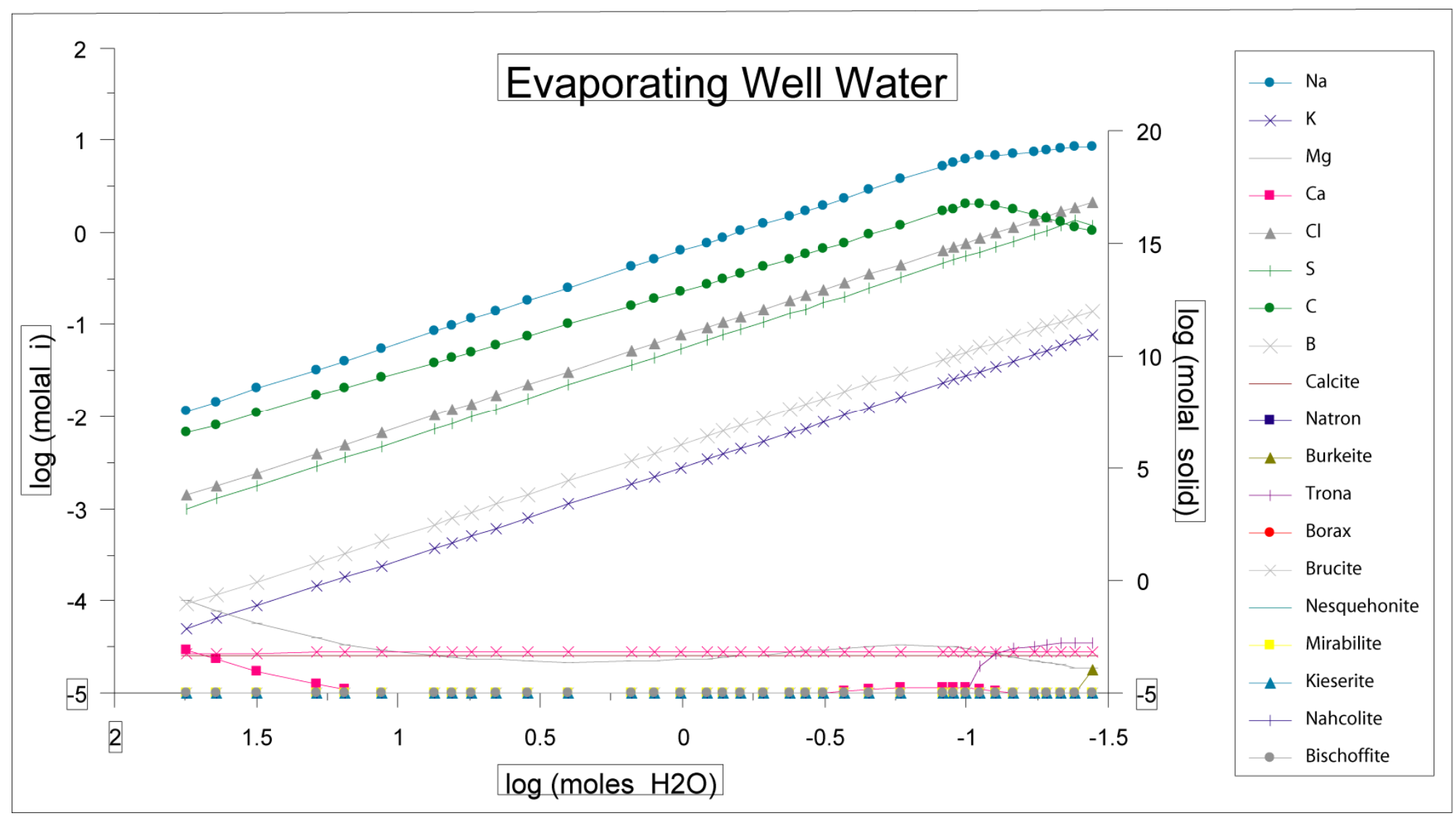

Figure 22: Modeled evaporation of water from Shar Burdiin Well using PHREEQC. The y-axis shows log moles of the activity of the constituents while the $\mathrm{x}$-axis shows log moles of water evaporated from the system. 


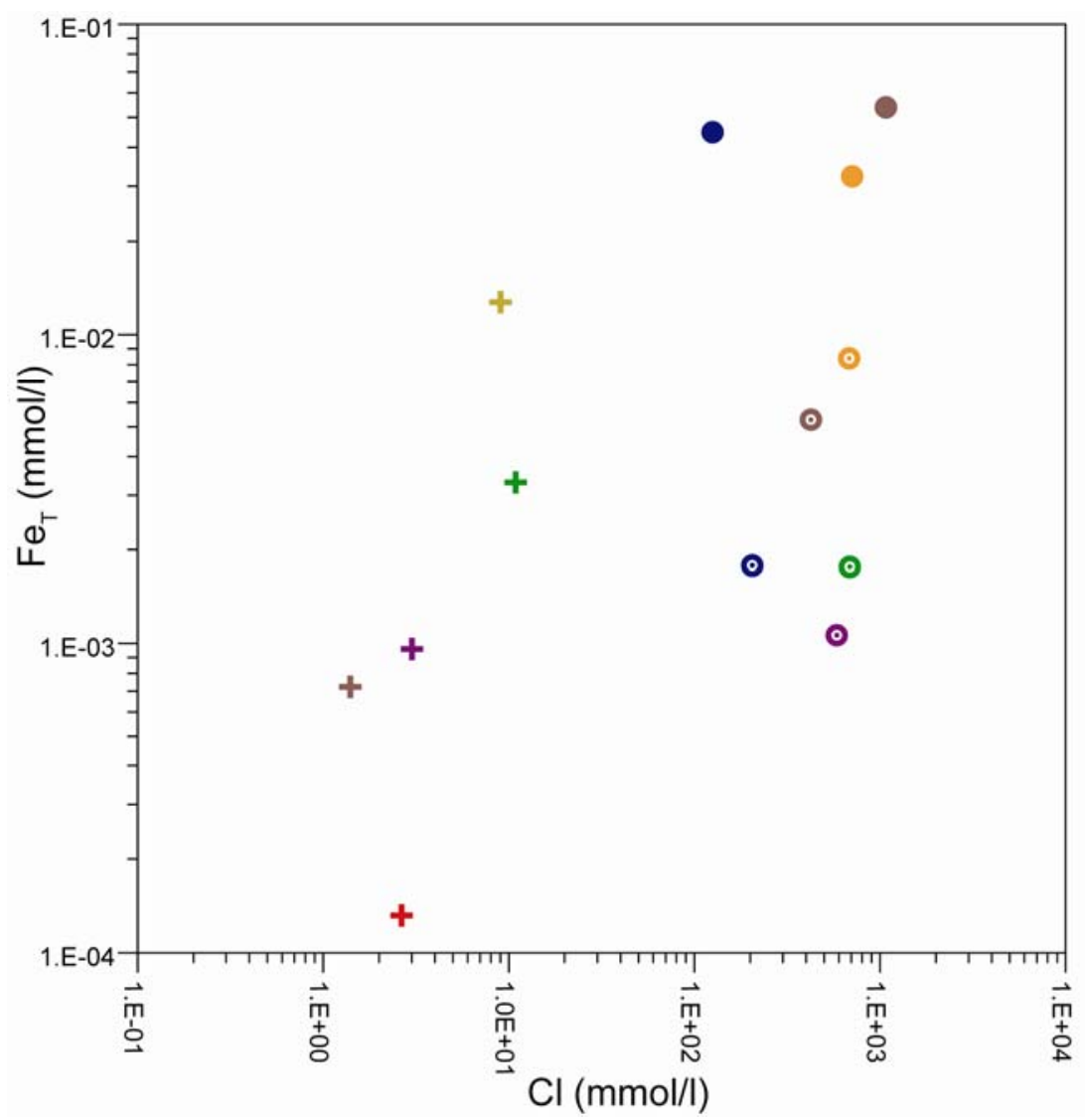

+ Background Well

- Gurvany-1 Lake

- Gurvany-1 Pore Water

- Gurvany-1 Stream

- Tsaidam-1 Lake

- Tsaidam-1 Pore Water

+ Tsaidam-1 Well 1

- Tsaidam-2 Pore Water

- Tsaidam-2 Lake

+ Tsaidam-2 Well 1

+ Tsaidam-2 Well 2

- Gurvany-2 Lake

( ) Gurvany-2 Pore Water

- Shar Burdiin Lake

- Shar Burdiin Pore Water

+ Shar Burdiin Well

Figure 23: $\mathrm{Fe}_{\mathrm{T}}$ versus $\mathrm{Cl}$ for wells, lakes, and pore waters. 


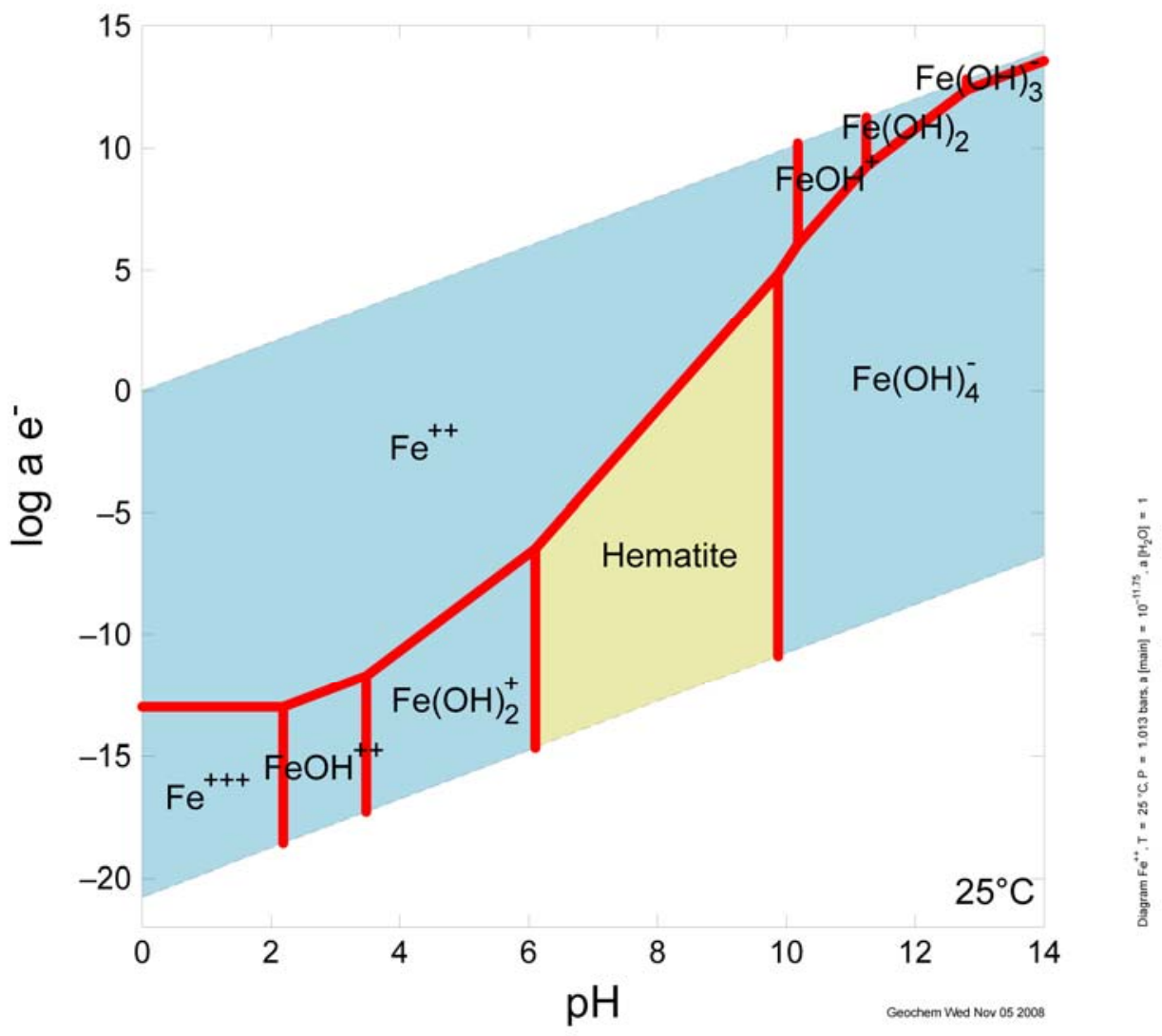

Figure 24: Iron speciation diagram created using Geochemist's Workbench ${ }^{\circledR}$. The diagram shows $\log$ activities on the $\mathrm{y}$-axis and $\mathrm{pH}$ on the $\mathrm{x}$-axis. $[\mathrm{Fe}]=\log$ $11.75, \mathrm{~T}=25^{\circ} \mathrm{C}, \mathrm{P}=1.013$ bars. 


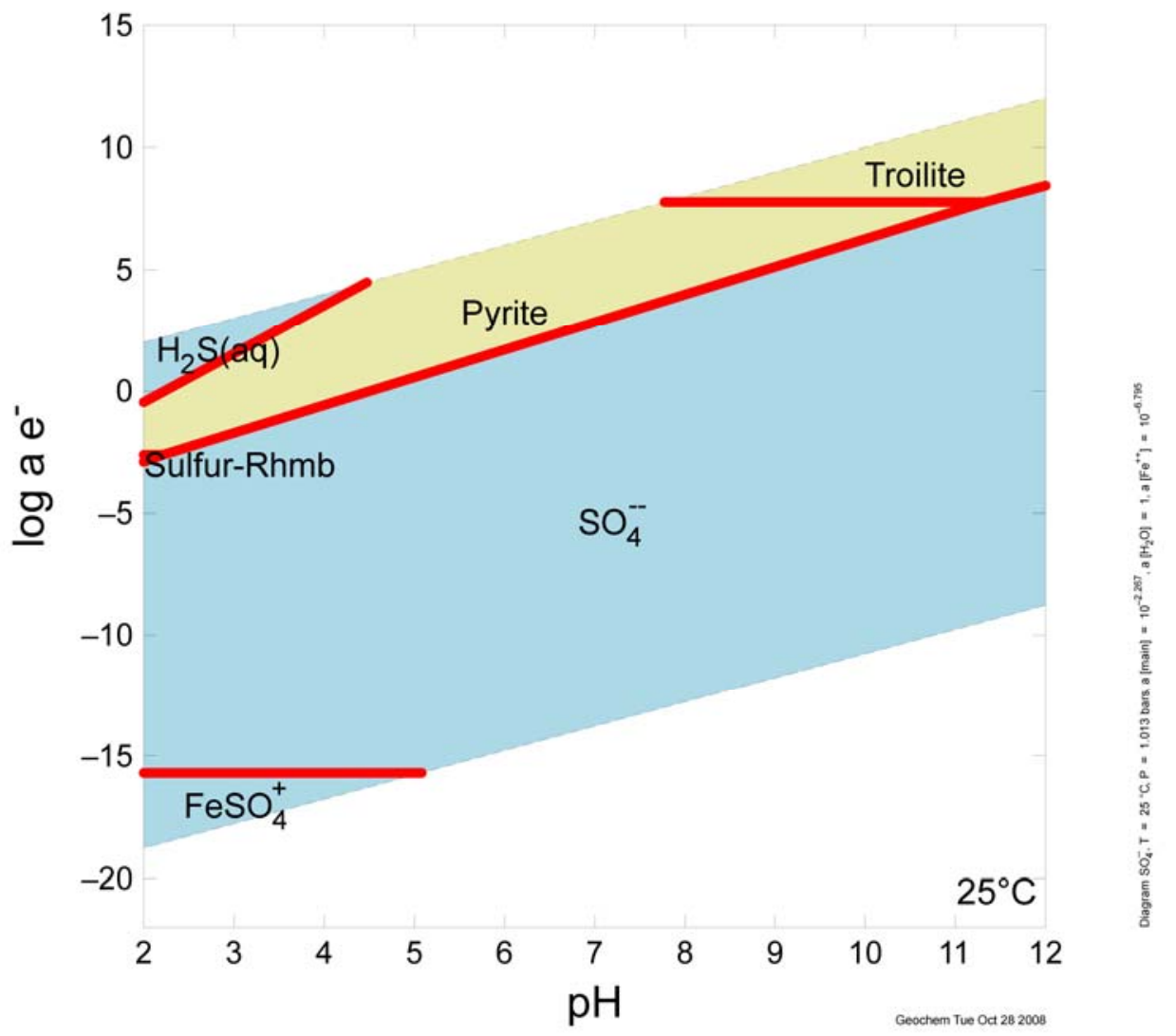

Figure 25: Sulfate speciation for conditions similar to Tsaidam-2 Lake. $\mathrm{T}=25^{\circ} \mathrm{C}$, $\mathrm{P}=1.013$ bars, $\left[\mathrm{SO}_{4}{ }^{-2}\right]=10^{-2.267},[\mathrm{Fe}++]=10^{-6.795}$. The diagram shows log activities on the $\mathrm{y}$-axis and $\mathrm{pH}$ on the $\mathrm{x}$-axis. It was created using Geochemist's Workbench ${ }^{\circledR}$. 


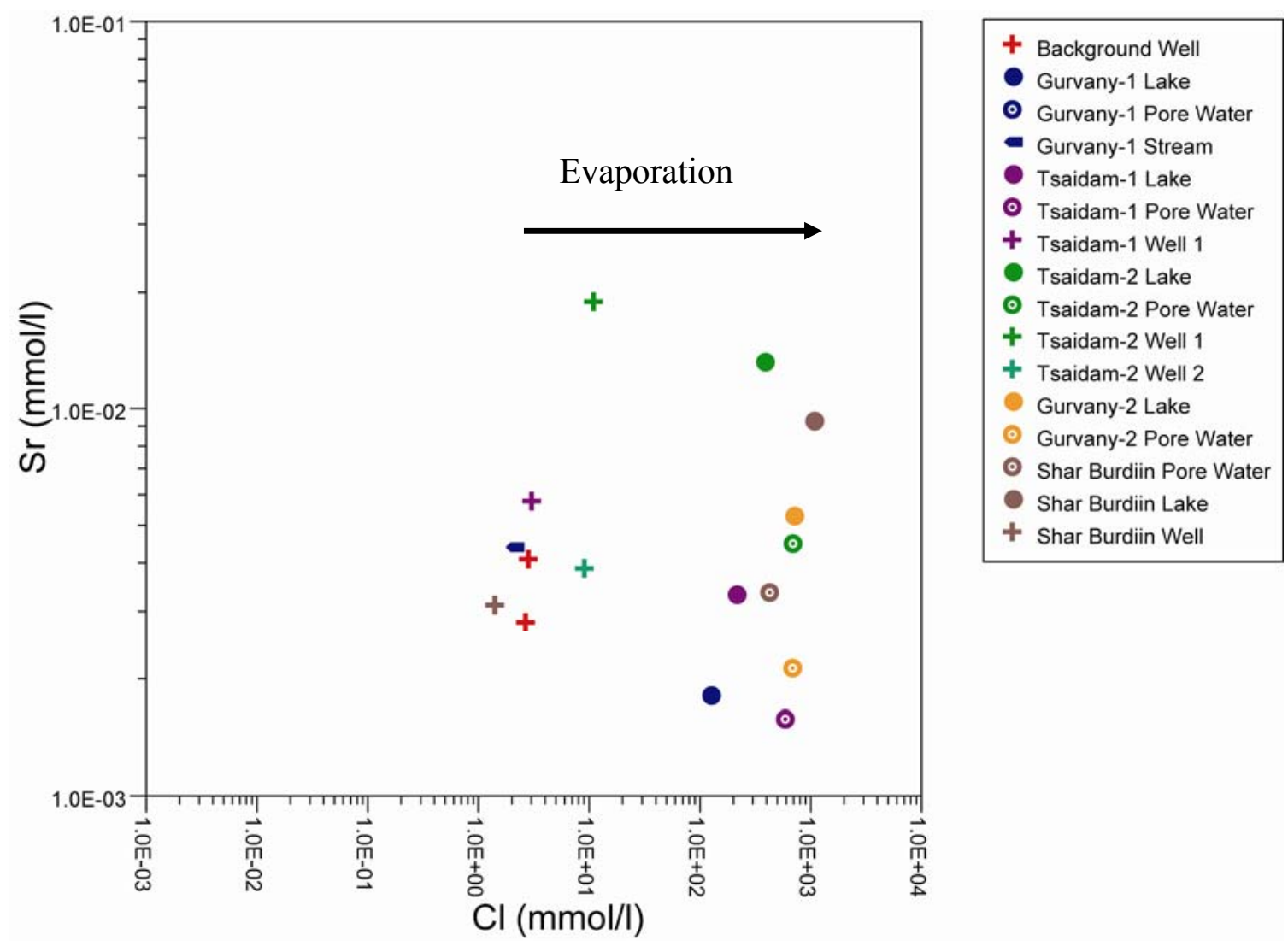

Figure 26: $\mathrm{Sr}$ versus $\mathrm{Cl}$ for all well, lake and pore water samples. The arrow shows the direction of increasing evaporation. 


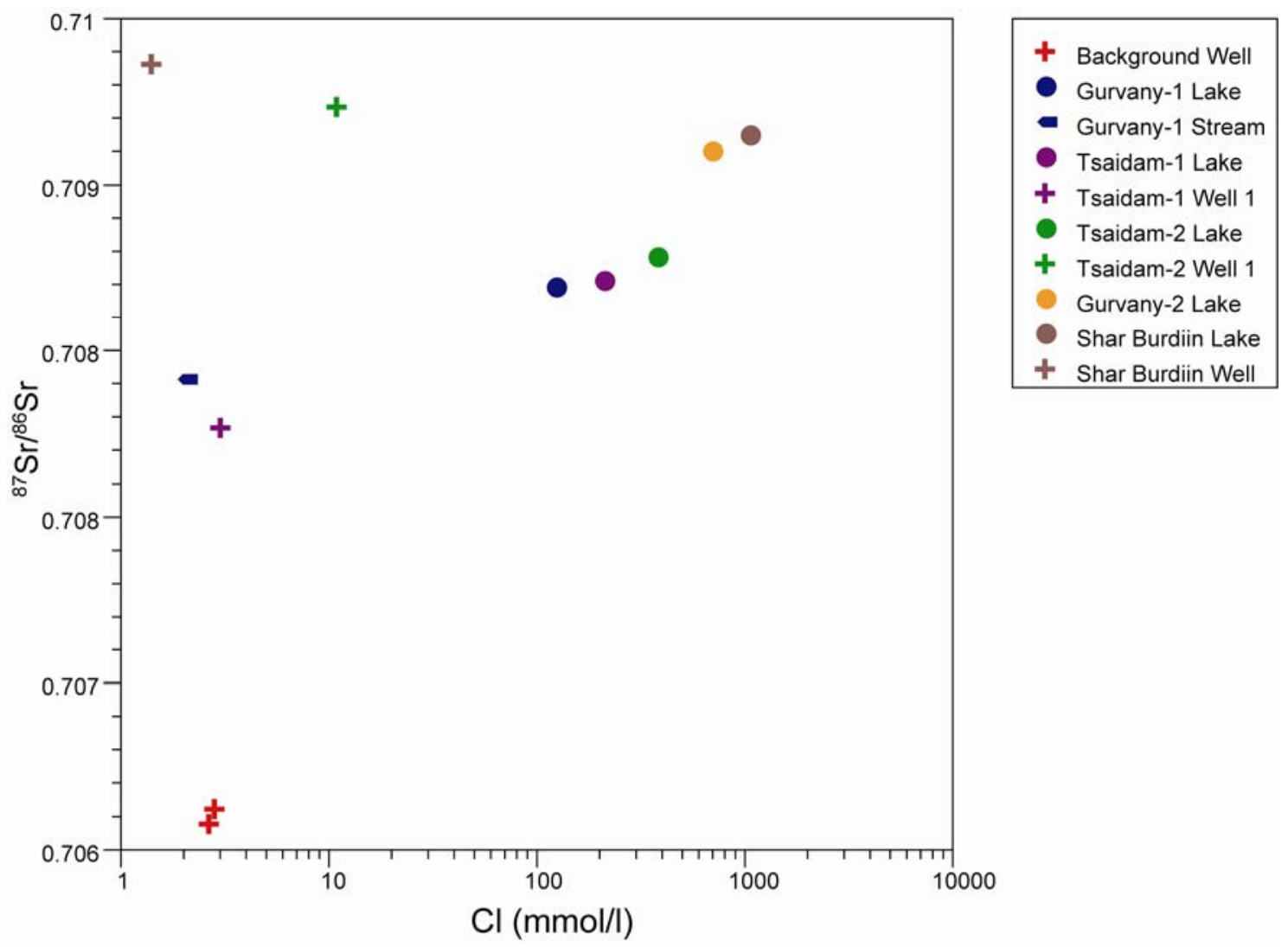

Figure 27: ${ }^{87} \mathrm{Sr} /{ }_{86} \mathrm{Sr}$ vs. $\mathrm{Cl}$ for groundwater and lake waters. 


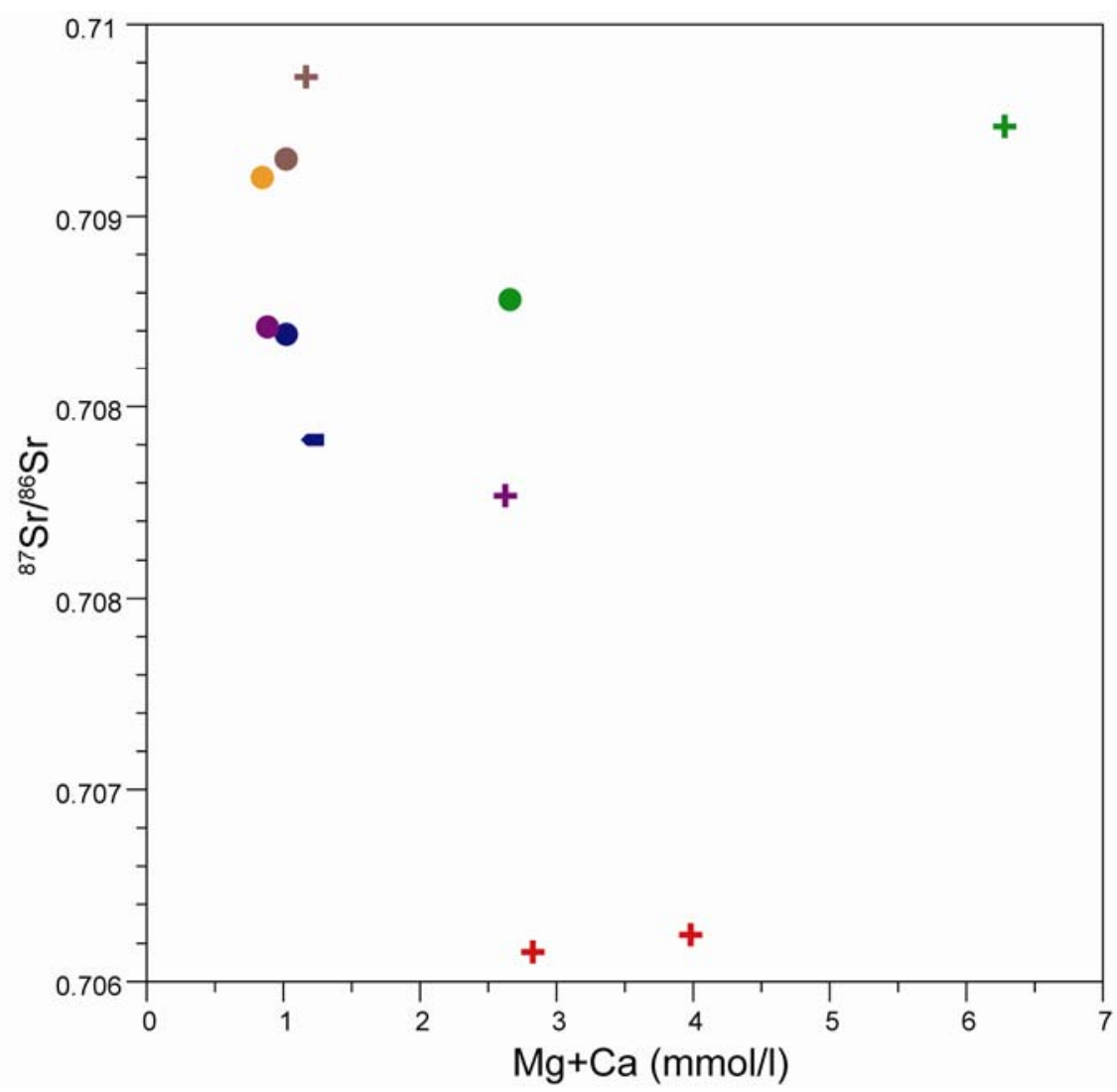

+ Background Well

- Gurvany-1 Lake

- Gurvany-1 Stream

+ Tsaidam-1 Well 1

- Tsaidam-1 Lake

- Tsaidam-2 Lake

+ Tsaidam-2 Well 1

- Gurvany-2 Lake

- Shar Burdiin Lake

+ Shar Burdiin Well

Figure 28: ${ }^{87} \mathrm{Sr} /{ }^{86} \mathrm{Sr}$ versus $\mathrm{Mg}+\mathrm{Ca}$ for wells and lake waters. 


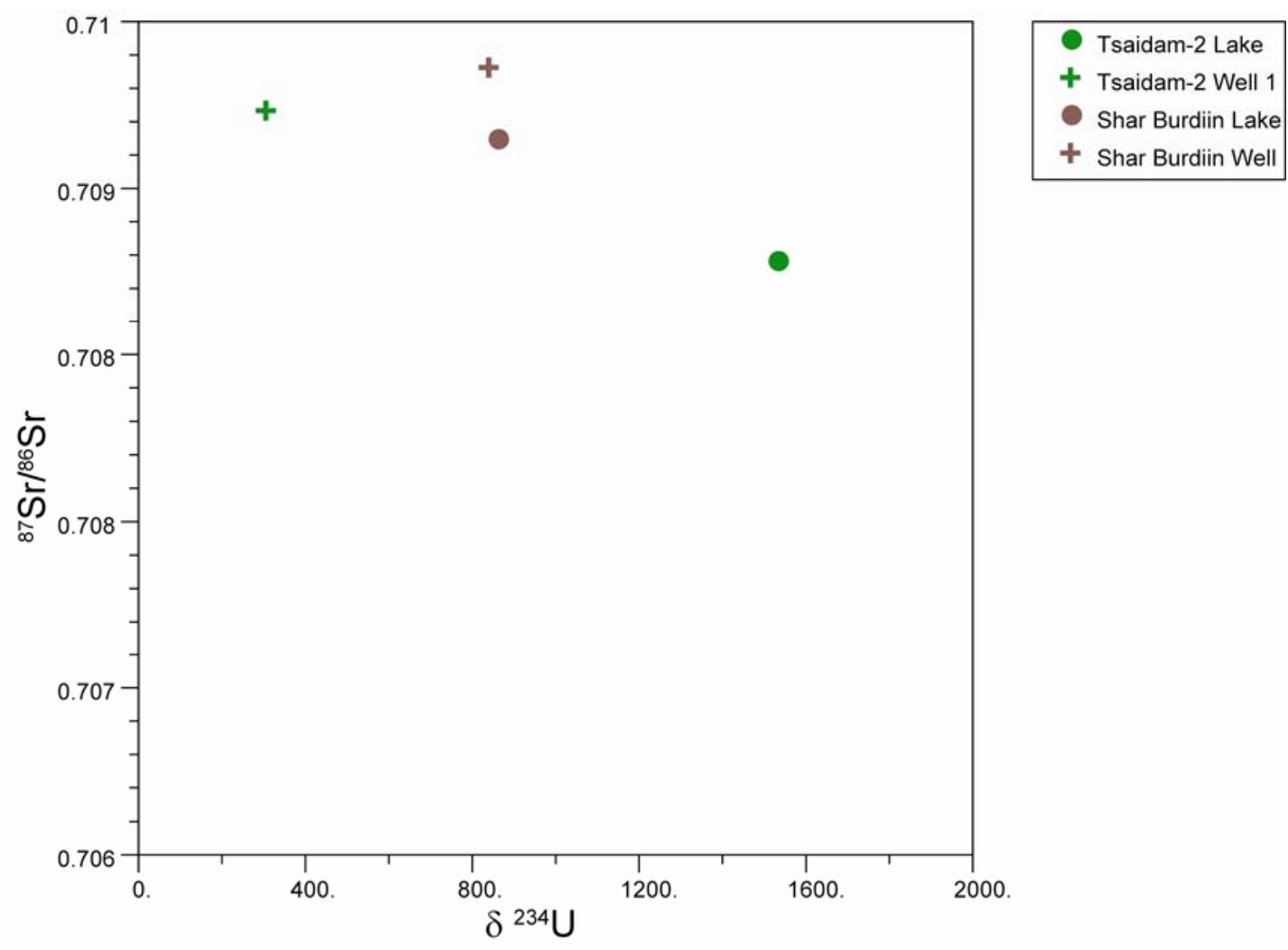

Figure 29: ${ }^{87} \mathrm{Sr} /{ }^{86} \mathrm{Sr}$ vs. $\delta^{234} \mathrm{U}$ for groundwater and lake water samples. 


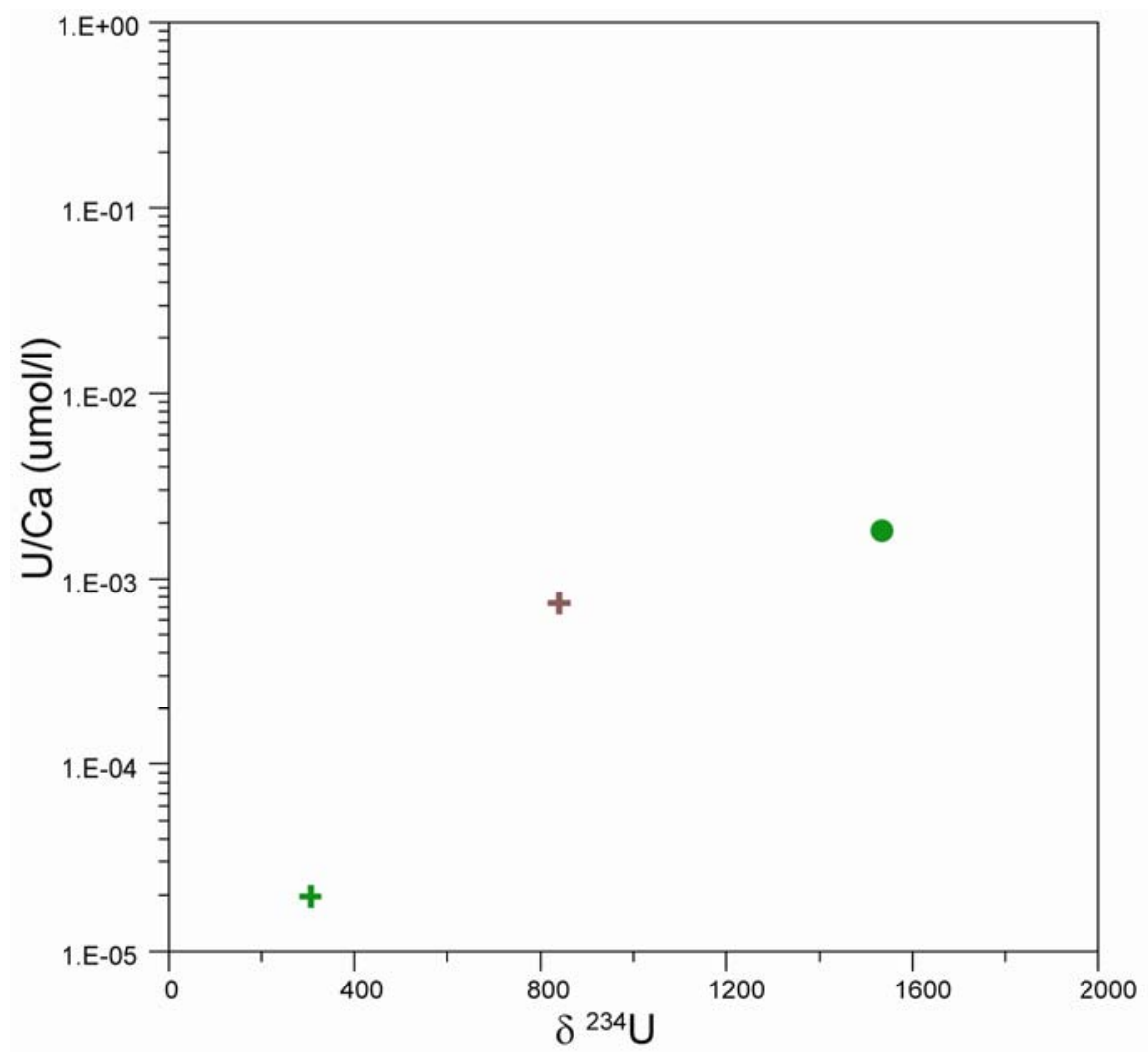

Tsaidam-2 Lake

+ Tsaidam-2 Well 1

+ Shar Burdiin Well

Figure 30: $\mathrm{U} / \mathrm{Ca}$ vs. $\delta^{234} \mathrm{U}$ for groundwater and Tsaidam-2 Lake water. 


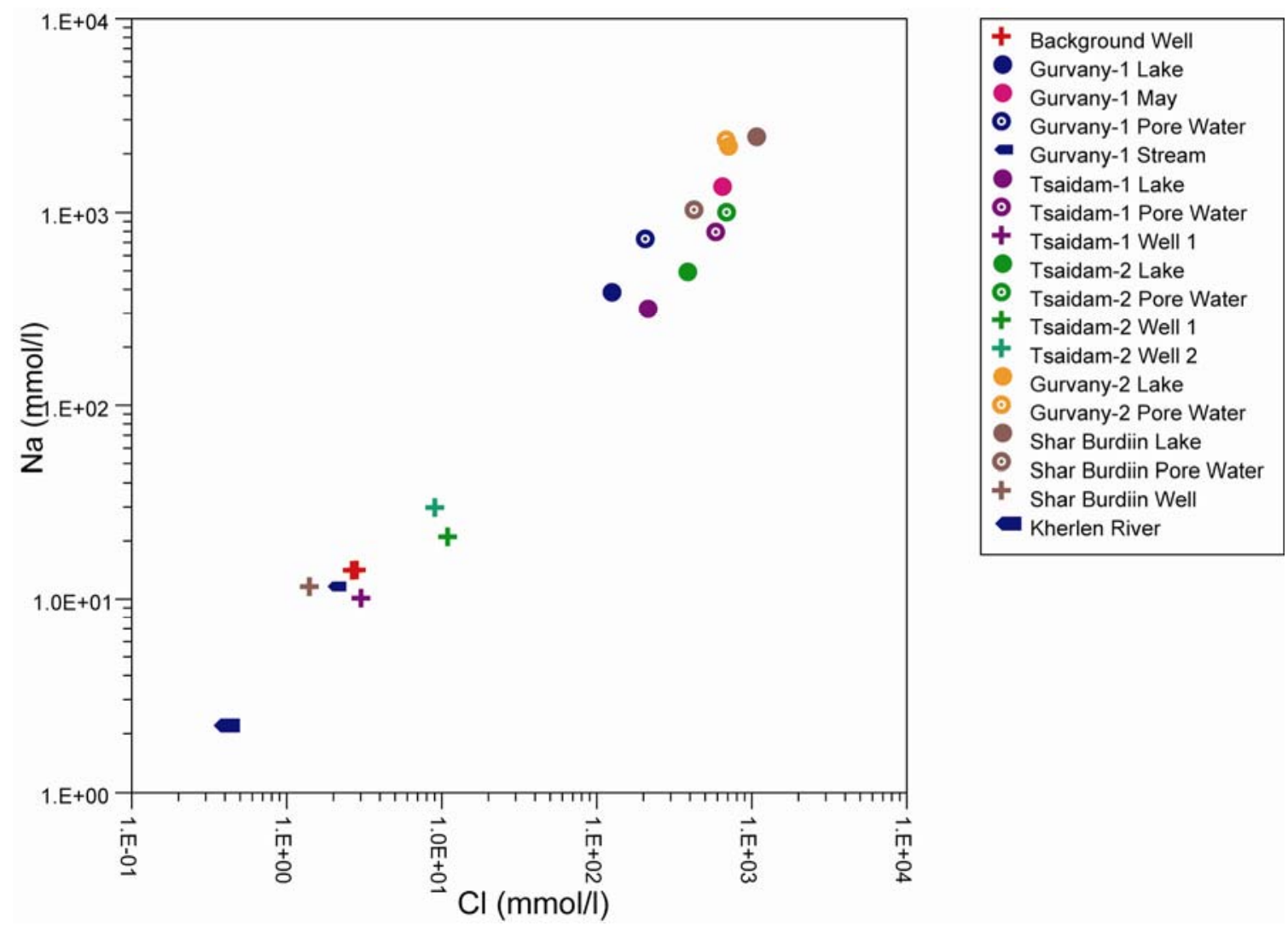

Figure 31: May sampling of Gurvany-1 Lake and Kherlen River plotted with samples taken in August. 


\section{APPENDIX A}

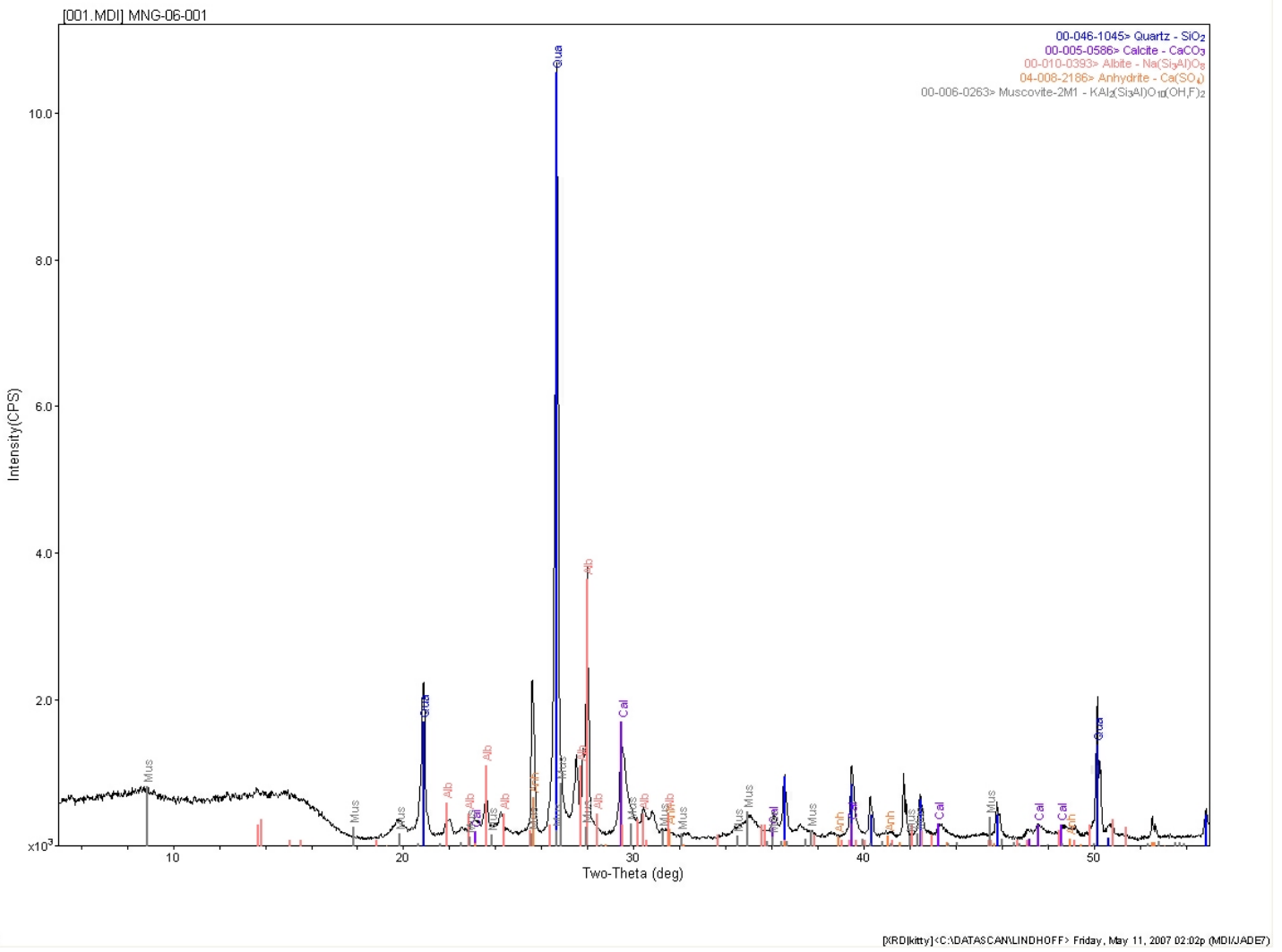

XRD analysis of sediment from Gurvany-1 Lake showing the presence of quartz, calcite, albite, anhydrite, and muscovite. 


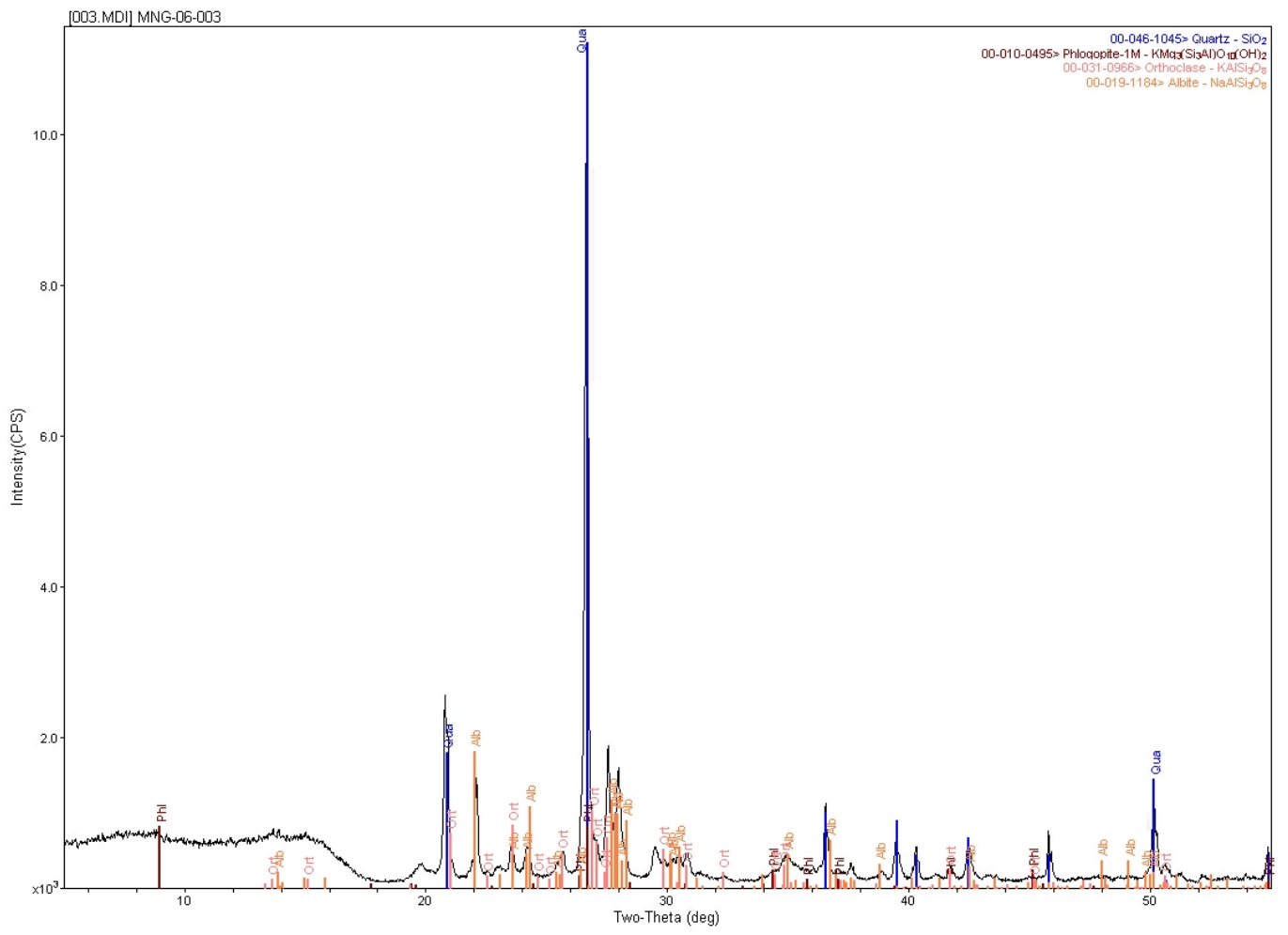

UT Austin XRD analysis of sediment from Shar Burdiin Lake showing the presence of quartz, phlogopite, orthoclase, and albite. 


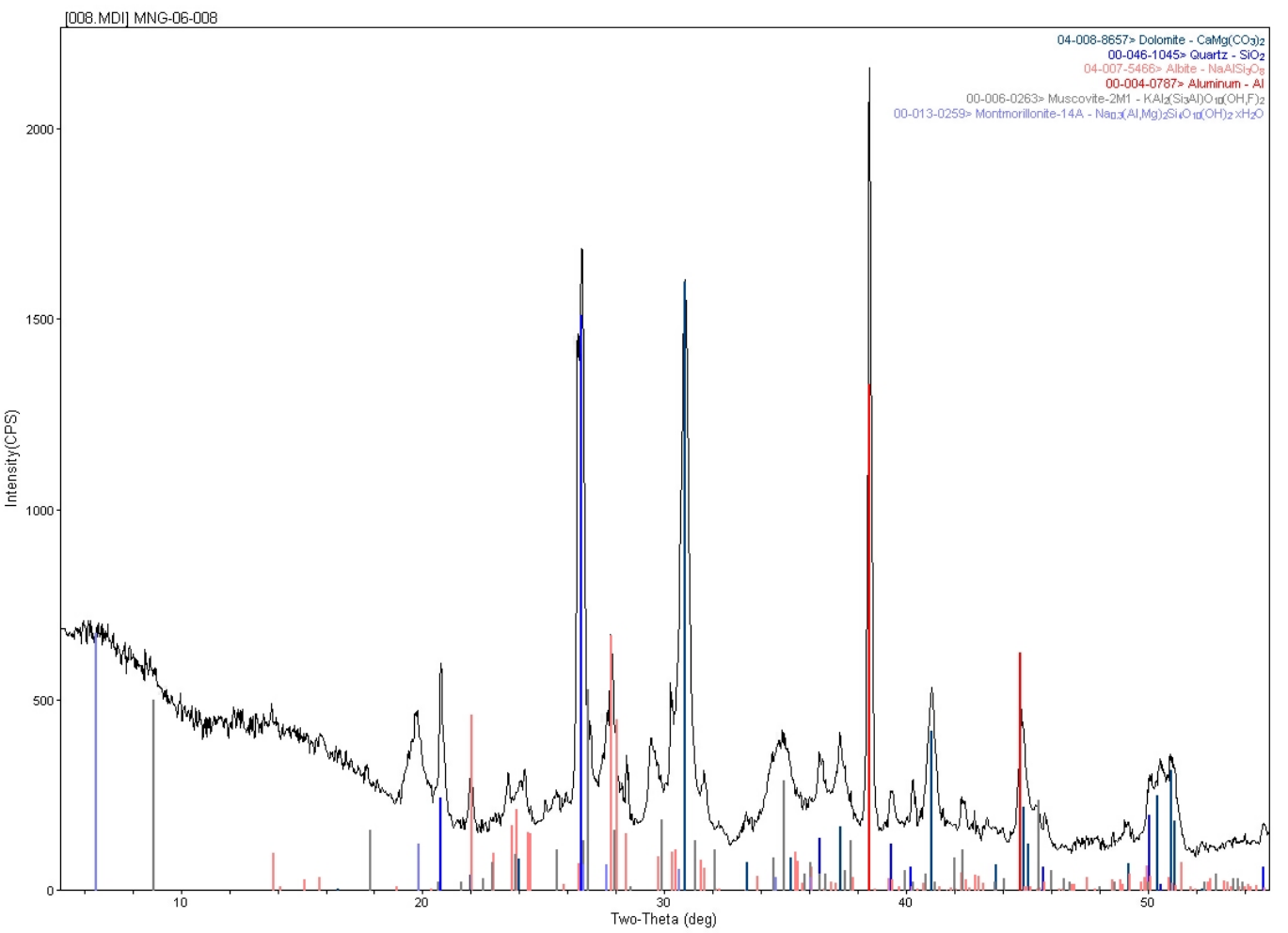

UT Austin XRD analysis of sediment from Tsaidam-1 Lake showing the presence of dolomite, quartz, albite, aluminum, muscovite, and montmorillonite. 


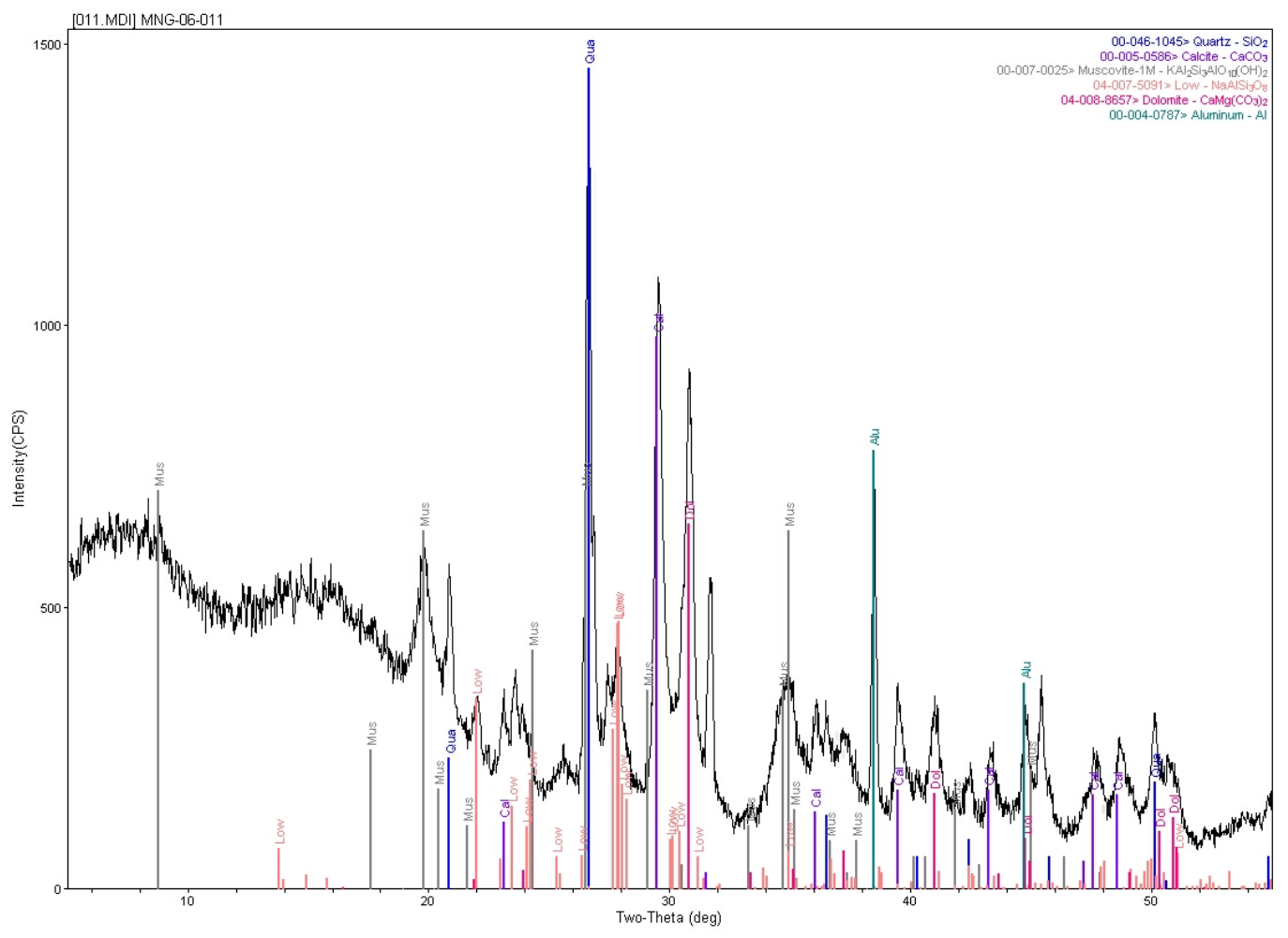

UT Austin XRD analysis of sediment from Tsaidam-2 Lake showing the presence of calcite, muscovite, orthoclase, dolomite, aluminum and montmorillonite.. 


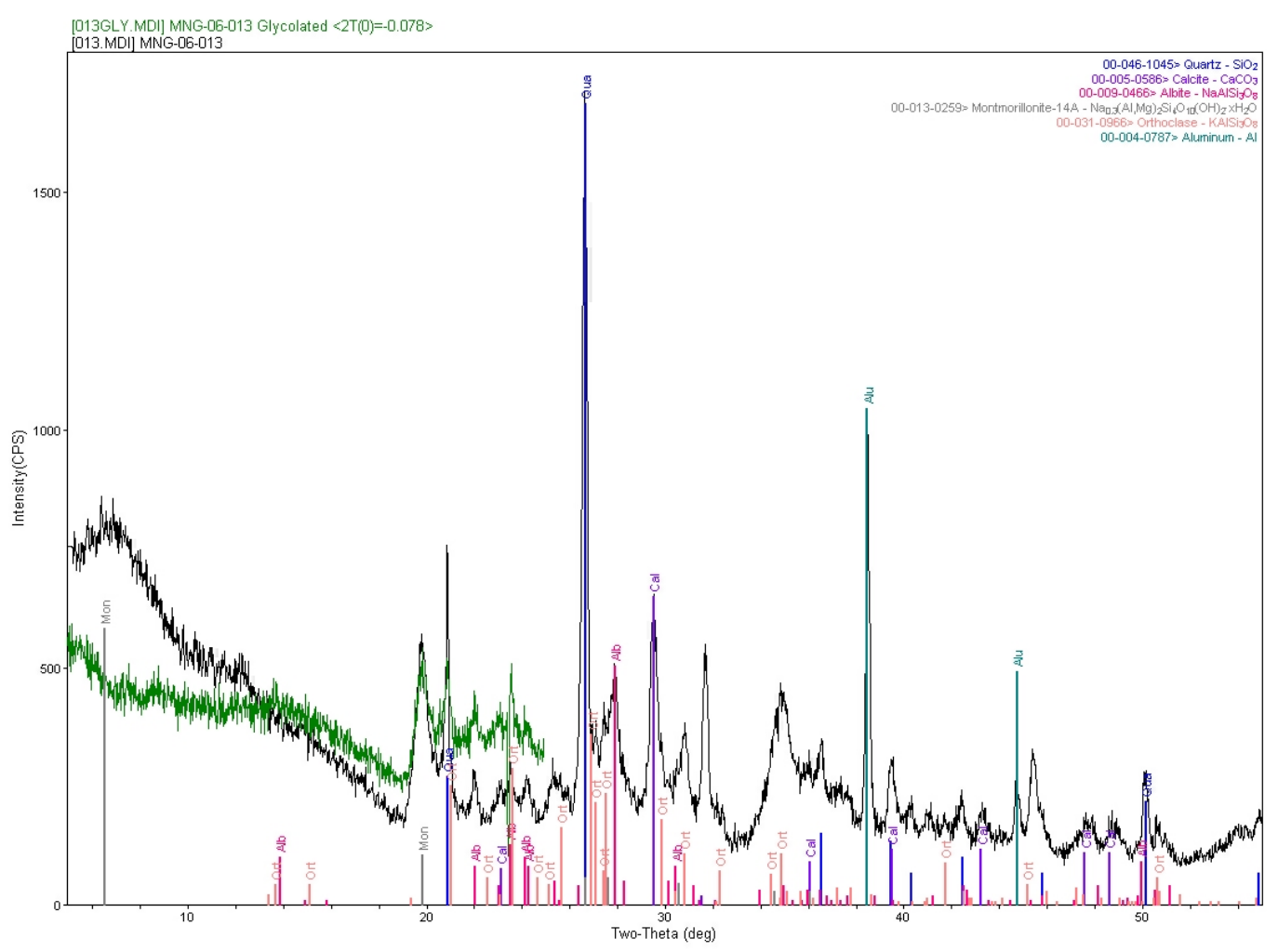

UT Austin XRD analysis of sediment from Gurvany-2 Lake showing the presence of quartz, calcite, albite, montmorillonite, orthoclase, and aluminum. 


\section{APPENDIX B}

Media for MPN designed for U-reducing bacteria in Shar Burdiin Lake

\begin{tabular}{l} 
Media \\
\begin{tabular}{|l|l|}
\hline Uranyl acetate & $1 \mathrm{~mL}$ of $0.5 \mathrm{M}$ \\
\hline $\mathrm{KH}_{2} \mathrm{PO}_{4}$ & $0.2 \mathrm{~g}$ \\
\hline $\mathrm{MgCl}_{2}{ }^{*} 6 \mathrm{H}_{2} \mathrm{O}$ & $0.1 \mathrm{~g}$ \\
\hline $\mathrm{NH}_{4} \mathrm{Cl}$ & $0.5 \mathrm{~g}$ \\
\hline $\mathrm{KCl}$ & $0.2 \mathrm{~g}$ \\
\hline $\mathrm{Na}$ acetate & $2 \mathrm{~g}$ \\
\hline Yeast extract & $0.1 \mathrm{~g}$ \\
\hline $\mathrm{NaCl}$ & $74.67 \mathrm{~g}$ \\
\hline $\mathrm{NaHCO}$ & $54.2082 \mathrm{~g}$ \\
\hline $\mathrm{Na} 2 \mathrm{CO}_{3}$ & $12.1 \mathrm{~g}$ \\
\hline Resazurin & $0.1 \mathrm{~mL}$ \\
\hline Cistine & $10 \mathrm{~mL}$ \\
\hline $\begin{array}{l}\text { Trace metal } \\
\text { solution }\end{array}$ & $1 \mathrm{~mL}$ \\
\hline
\end{tabular} \\
\hline
\end{tabular}




\section{REFERENCES}

Agnerian, J., K. Bocking, J. Cox and L. Heymann (2007). Technical report on the Dornod Uranium Project, Mongolia. Prepared for Khan Resources Inc., Scott Wilson Roscoe Postle Associates Inc.

Anderson, P. S., G. J. Wasserburg and J. Ingri (1992). "The sources and transport of Sr and Nd isotopes in the Baltic Sea." Earth Planet Science Letters 113: 459-472.

Anderson, R. and D. R. Lovley (2002). Microbial redox interactions with uranium: environmental perspective, Elservier Science Ltd.

Andrew, J. N. and R. L. F. Kay (1983). "The U contents and 234U/238U activity ratio of dissolved uranium in groundwaters from some Triassic sandstones in England." Isotope Geosciences 1: 101-117.

Banner, J. L. (2004). "Radiogenic isotopes: systematics and applications to the earth surface processes and chemical stratigraphy." Earth Science Reviews 65: 141194.

Banner, J. L., M. Musgrove and R. C. Capo (1994). "Tracing ground-water evolution in a limestone aquifer using Sr isotopes: Effects of multiple sources of dissolved ions and mineral-solution reactions." Geology 22(8): 687-690.

Banner, J. L., G. J. Wasserburg, P. F. Dobson, A. B. Carpenter and C. H. Moore (1989). "Isotopic and trace element constraints on the origin and evolution of saline groundwater from central Missoui." Geochimica et Cosmochimica Acta 53: 383398.

Beadle, L. C. (1932). "Scientific results of the Cambridge Expedition to the East African lakes. 4. The waters of some East African lakes in relation to their fauna and flora." Journal of Limnological Society, Zoology 38: 128-138.

Braaten, D. A. and T. A. Cahill (1986). "Size and commposition of Asian dust transported to Hawaii." Atmospheric Environment 20(6): 1105-1109.

Brady, P. and J. Walther (1989). "Controls on silicate dissolution rates in neutral and basic pH solutions at $25^{\circ} \mathrm{C}$." Geochimica et Cosmochimica Acta 53: 2823-2830. 
Brass, G. W. (1976). "The variation of the marine $87 \mathrm{Sr} / 86 \mathrm{Sr}$ ratio during Phanerozoic time: interpretation using a flux model." Geochimica et Cosmochimica Acta(7): 701-860.

Chang, Y.-J., A. Peacock, P. Long, J. Stephen, J. McKinley, S. Macnaughton, A. Hussan, A. Saxton and D. White (2001). "Diversity and characterization of sulfatereducing bacteria in groundwater at a uranium mill tailings site." Applied and Environmental Microbiology 67: 3149-3160.

Cochran, J. K., A. E. Carey, E. R. Sholkovitz and L. D. Surprenant (1986). "The geochemistry of uranium and thorium in coastal marine sediments and sediment pore waters." Geochimica et Cosmochimica Acta 50: 663-680.

Davis, J., G. Curtis, M. Wilkins, M. Kohler, P. Fox, D. Naftz and J. Lloyd (2006). "Processes affecting transport of uranium in a suboxic aquifer." Physics and Chemistry of the Earth 31: 548-555.

Dickson, B. L. and M. R. Davidson (1985). "Interpretation of 234U/238U activity in groundwaters." Chemical Geology (Isotope Geoscience Section) 58: 83-88.

Dodonov, A. E. (1979). "Stratigraphy of the Upper Pliocene-Quaternary deposits of Tadjikistan (Soviet Central Asia)." Acta. Geol. Acad. Sci. Hung. 22: 63-73.

Dodonov, A. E. (1991). "Loess of Central Asia." GeoJournal 24.2: 185-194.

Drever, J. I. (1997). The Geochemistry of Natural Waters: Surface and Groundwater Environments. Upper Saddle River, Simon and Schuster/A Viacom Company: 185.

Duce, R. A., R. Arimoto, B. J. Ray, K. Unni and P. J. Harder (1983). "Atmospheric trace elements at Enewetak Atoll: 1, Concentrations, sources, and temporal variability." Journal of Geophysical Research 88: 5321-5342.

Echigo, A., M. Hinon, T. Fukushima, T. Mizuki, M. Kamekura and R. Usami (2005). "Endospores of halophicl bacteria of the family Bacillaceae isolated from nonsaline Japanese soil may be tansported by Kosa event (Asian dust storm)." Saline Systems 1(8): 1-13.

Egorov, A. N. (1993). "Mongolian salt lakes: some features of their geography, thermal patterns, chemistry and biology." Hydrobiologia 267: 13-21.

EPA (2003). National Primary Drinking Water Standards, Environmental Protection Agency. 
Eugster, H. P. and L. A. Hardie (1978). Saline Lakes. Lakes: Chemistry, Geology, Physics. New York, Springer-Verlag: 237-293.

Faure, G. and J. L. Powell (1972). Strontium isotope geology. New York, SpringerVerlag.

Fox, P., J. Davis and J. M. Zachara (2006). "The effect of calcium on aqueous uranium(VI) speciation and adsorption to ferrihydrite and quartz." Geochimica et Cosmochimica Acta 70(6): 1379-1387.

Friedrich, M. and M. Cuney (1989). Uranium enrichment processes in peraluminous magmatism. In Uranium deposits in magmatic and metamorphic rocks. Vienna, International Atomic Energy Agency, : 11-35.

Gorby, Y. A. and D. R. Lovley (1992). "Enzymatic Uranium Precipitation." Environmental Science and Technology 26(1): 205-207.

Gosselin, D. C., S. Sibray and J. Ayers (1994). "Geochemistry of K-rich alkaline lakes, Western Sandhills, Nebraska, USA." Geochimica et Cosmochimica Acta 58(5): 1403-1418.

Guillaumont, R., T. Ranghanel, J. Fuger, I. Grenthe, V. Neck, D. Palmer and M. Rand (2003). Update on the chemical thermodynamics of uranium, neptunium, and plutonium, americcium, and technetium. Amsterdam, Elsevier: 919.

Haas, J. R., T. J. Dichristina and R. J. Wade (2001). "Thermodynamics of U(VI) sorption onto Shewanella putrefaciens." Chemical Geology 180: 33-54.

Hardie, L. A. and H. P. Eugster (1970). "The evolution of closed-basin brines." Mineralogical Soc. Am. Spec. Publ. 3: 273-290.

Henderson, G. M., B. L. Hall, A. Smith and L. F. Robinson (2005). "Control on (234U/238U) in lake water: A study in the Dry Valleys of Antarctica." Chemical Geology 226: 298-308.

Husa, R. B., D. M. Tratt, B. A. Schichtel, F. L. Falke, S. Jaffe, T. Gasso, N. S. Gill, M. Lu, C. Rebesis, Y. Chun, D. Westphal, B. N. Holben, C. Gueymard and N. McKendry (2001). "Asian dust events of 1998." Journal of Geophysical Research 106(D16): 18317-18330.

Ingram, B. L. and D. Sloan (1992). "Strontium isotope comosition of estuarine sediments as paleosalinity-paleoclimate indicator." Science 255(5040): 68-72. 
Jaffey, A. H., K. F. Flynn, L. E. Glendenin, W. C. Bentlley and A. M. Essling (1971). "Precision measurements of half-lives and specific activities of $235 \mathrm{U}$ and 238U." Physics Revisions C4: 1889-1906.

Jenkin, P. M. (1932). "Reports on the Percy Sladen Expedition to some Rift Valey Lakes in Kenya in 1929. I. Introductory account of the Biological Survey of five freshwater and alkaline lakes." Ann. Mag. nat. Hist., 10(9): 533-553.

Jensen, M. L. (1958). "Sulfur isotopes and the origin of sandstone-type uranium deposits [Colorado Plateau Wyoming]." Economic Geology 53(5): 598-616.

Johannesson, K. H. and W. B. Lyons (1994). "The rare earth element geochemistry of Mono Lake water and the importance of carbonate compexing." Limnology and Oceanography 39(5): 1141-1154.

Jones, B. F., H. P. Eugster and S. L. Rettig (1977). "Hydrochemistry of the Lake Magadi basin, Kenya." Geochimica et Cosmochimica Acta 41: 53-72.

Jones, B. F. and A. S. Van Denburgh (1966). "Geochemical influences on the chemical character of closed lakes." Hydrology of lakes and reservoirs 70: 435-446.

Jones, L. M. and G. Faure (1978). "A study of strontium isotopes in lakes and surficial deposits of the ice-free valleys, Southern Victoria Land, Antarctica." Chemical Geology 22: 107-120.

Katz, J. J., G. T. Seaborg and L. R. Morss (1986). The Chemistry of the Actinide Elements. Chicago, Chapman and Hall Ltd.

Kigoshi, K. (1971). "Alpha recoil thorium-234: Dissolution into water and uranium234/uranium-238 disequilibrium in nature." Science 173: 47-48.

Klinkhammer, G. P. and M. R. Palmer (1991). "Uranium in the oceans: Where it goes and why." Geochimica et Cosmochimica Acta 55: 1799-1806.

Knutson, E. and K. Tu (1996). "Size distribution of radon progeny aerosol in the working area of a dry former uranium mine." Environmental International 22: 5617-5632.

Krishnawami, S., J. R. Trivedi, M. M. Starin, R. Ramesh and K. K. Sharma (1992).

"Strontium isotopes and rubidium in the Ganga-Bahmautra river system: Weathering in the Himalaya, fluxes to the Bay of Bengal and contributions to the evolution of oceanic 87Sr/86Sr." Earth and Planetary Science Letters 109: 243253. 
Ku, T. (1977). "Uranium in open ocean: concentration and iotopic composition." Deep Sea Research 24(11): 1005-1017.

Kurttio, P., A. Auvinen, L. Salonen, H. Saha, J. Pekkanen, I. Makelainen, S. Vaisanen, I. Penttila and H. Komulainen (2002). "Renal effects of uranium in drinking water." Environmental Health Perspectives 110(4): 337-342.

Langmuir, D. (1978). "Uranium solution-mineral equilibria at low-temperatures with applications to sedimentary ore-deposits." Geochimica et Cosmochimica Acta 42: 547-569.

Lloyd, J. and L. E. Macaski (2000). Bioremediation of radionuclide-contaminated wastewaters. In environmental microbe-metal interactions environmental microbe-metal interactions L. D. R. Ed. Washington, D.C., ASM Press: 277-327.

Lovley, D. R., E. J. P. Phillips, Y. A. Gorby and E. R. Landa (1991). "Microbial reduction of uranium." Nature 350: 413-416.

Lovley, D. R., J. F. Stolz, G. L. Nord and E. J. P. Phillips (1987). "Anaerobic production of magnetite by a dissimilatory iron-reducing microorganism."

Lyons, B. W., M. J. SPENCER, M. E. HINES and H. E. GAUDETTE (1988). "The trace metal geochmistry of pore water brines from two hypersaline lakes." Geochimica et Cosmochimica Acta 52: 265-274.

Lyons, B. W., S. W. Tyler, H. E. Guaudette and D. T. Long (1995). "The use of strontium isotopes in determining groundwater mixing and bine figering in playa spring zone, Lake Tyrell, Australia." Journal of Hydrology 167(1-4): 225-239.

Markwitz, A., B. Barry and D. Shagjjamba (2008). "PIXE analysis of sand and soil from Ulaanbaatar and Karakurum, Mongolia." Nuclear Instruments and Methods in Physics Research B 266: 4010-4019.

McNutt, R. H., S. K. Frape and P. Fritz (1984). "Strontium isotopic composition of some brines from the Precambrian shield of Canada." Isotope Geosciences 2: 205-215.

Mironov, Y. B. (2006). Uranium of Mongolia. London, Centre for Russian and Central EurAsian Mineral Studies.

Musgrove, M., J. L. Banner, D. M. Combs, E. W. James, H. Cheng and R. L. Edwards (2001). "Geochronology of late Pleistocene to Holocene speleothems from central 
Texas: Implications for regional paleoclimate." GSA Bulletin 113(12): 15321543.

Onodera, S. (1996). "The mechanism of concentrated groundwater recharge in a tropical semiarid region." Japan Journal of Hydrological Science 26: 87-98.

Parkhurst, K. L. and C. A. J. Appelo (1999). "Users' guide to PHREEQC (Version 2)- A computer program for speciation, batch-reaction, one-dimenstional transport, and inverse geochemical calculations." U.S. Geological Survey Water-Resources Investigations Report 99-4259: 310 .

Rich, F. (1932). "Reports on the Percy Sladen Expedition to some Rift Valley lakes in Kenya in 1929. IV. Phytoplankton from some Rift Vallyey lakes in Kenya." Ann. Mag. nat. Hist., 10(10): 233-262.

Rosholt, J. N., W. R. Shields and E. L. Garner (1963). "Isotopic fractionation of uranium in sandstone." Science 139: 224-226.

Scholl, D. and W. H. Taft (1964). "Algae, Contributors to the formation of calcareous tufa, Mono Lake, California." Juornal of Sedimentary Petrology 34(2): 309-319.

Seiler, R. L. (2004). "Temporal changes in water quality at a chilhood leukemia cluster." Ground Water 42(3): 446-455.

Shoikhet, Y., V. Loborev, V. Sudakov, V. I. Kiselev, V. Zelenov and L. Azarov (2002). "Fallout from nuclear tests: dosimetry in the Altai reegion." Radiation Environmental Biophysics 41: 57-60.

Simpson, H. J., R. M. Trier, C. R. Olsen, L. Miller and J. M. Melack (1980). "Fallout Plutonium in an alkaline, saline lake." Science 207: 1071-1072.

Simpson, H. J., R. M. Trier, J. R. Toggweiler, G. Mathieu, B. L. Deck and R. Olsen (1982). "Radionuclides in Mono Lake, California." Science 216: 512-514.

Sorokin, D. Y., V. M. Gorlenko, B. B. Namsaraev, Z. B. Namsaraev, A. M. Lysenko, B. T. Eshinimaev, V. N. Khmelenina, T. Y. A. and J. G. Kuenen (2004). "Prokaryotic communities of the north-eastern Mongolian soda lakes." Hydrobiologia 522: 235-248.

Sorokin, D. Y., V. M. Gorlenko, T. y. P. Tourova, A. I. Tsapin, K. H. Nealson and J. G. Kuenen (2002). "Thioalkalimicrobium cyclicum sp. nov. and Thioalkalivibrio jannaschii sp. nov., novel species of haloalkaliphilic, obligately chemolithoautotrophic sulfur-oxidizing bacteria from hypersaline alkaline Mono 
Lake (California)." International Journal of Systematic and Evolutionary Microbiology 52: 913-920.

Sorokin, D. Y., T. y. P. Tourova, M. C. Schmid, M. Wagner, H.-P. Koops, J. G. Kuenen and M. Jetten (2001). "Isolation and properties of obligately chemolithoautotrophic and extremely alkali-toerant ammonia-oxidizing bacteria from Mongolian soda lakes." Archives of Microbiology 176: 170-177.

Stumm, W. and J. J. Morgan (1996). Aquatic Chemistry Chemical, Equilibria and Rates in Natural Waters, John Wiley and Sons, Inc.

Sublette, C. (2001). "Nuclear Weapons Frequently Asked Questions." Retrieved November 6, 2008, from www.milnet.com/nukeweap/Nfaq12.html.

Sugita, M., J. Asanuma, M. Tsurjimura, S. Mariko, M. Lu, F. Kimura, D. Azzaya and T. Adyasuren (2007). "An overview of the rangelands atomosphere-hydrospherebiosphere interaction sutdy experient in northeastern Asia (RAISE)." Journal of Hydrology 333: 3-20.

Suzuki, Y. and J. F. Banfield (1999). Geomicrobiology of Uranium. Uranium: Mineralogy, Geochemistry and the Environment. P. C. Burns and R. Finch. Washington, D.C., Mineralogical Society of America. 38: 392-432.

Suzuki, Y. and J. F. Banfield (2004). "Resistance to, and accumulation of, uranium bacteria from a uranium-contaminated site." Geomicrobiology Journal 21: 113121.

Tebo, B. M. and A. Y. Obraztsova (1998). "Sulfate-reducing bacterium grows with $\mathrm{Cr}$ (VI), U(VI), Mn(IV), and FE(III) as electron acceptors." FEMS Microbiology Letters(162): 193-198.

Trivedi, P., J. Dyer and D. Sparks (2003). "Lead sorption into ferrihydrite. 1. A macroscopic and spectroscopic assessment." Environmental Science and Technology 37: 908-914.

Tsurjimura, M., Y. Abe, T. Tanaka, J. Shimada, S. Higuchi, T. Yamanaka, G. Davaa and D. Oyunbaatar (2007). "Stable isotopic and geochemical characteristics of groundwater in Kherlen River basin, a semi-arid region in eastern Mongolia." Journal of Hydrology 333: 47-57.

Turekian, K. K. and K. H. Wedepohl (1961). "Distribution of the elements in some major units of the Earth's crust." Geological Society of America Bulletin 72: 175-192. 
Uematsu, M., R. A. Duce, J. M. Prospero, L. Chen, J. T. Merrill and R. L. McDonald (1983). "Transport of mineral aerosol from Asia over the north Pacific ocean." Journal of Geophysical Research 88(5343-5352).

Wadleigh, M. A. and C. Brooks (1985). "Strontium and its isotopes in Canadian rivers: fluxes and global implications." Geochimica et Cosmochimica Acta(49): 17271736.

Williams, W. D. (2006). "Chinese and Mongolian saline lakes: a limnological overview." Hydrobiologia 210(1-2): 39-66.

Yamanaka, T., M. Tsurjimura, D. Oyunbaatar and G. Davaa (2005). "Isotopic variation of precipitation over eastern Mongolia and its implication for the atmospheric water cycle." Journal of Hydrology 333: 21-34.

Zavarzina, D. G., T. V. Kolganova, E. S. Boulygina, N. A. Kostrikina, T. P. Tourova and G. A. Zavarzin (2006). "Geoalkalibacter ferrihydriticus gen. nov. sp. nov., the first alkaliphilic representative of the family geobacteraceae, isolated from a soda lake." Microbiology 75(6): 673-682.

Zhang, X. Y., S. L. Gong, T. L. Zhao, R. Armimoto, Y. Q. Wang and Z. J. Zhou (2003). "Sources of Asian dust and role of climate change versus desertification in Asian dust emission." Geophysical Research Letters 30(24): 8-1, 8,4.

Zhang, Y., M. Ishikawa, T. Ohata and D. Oyunbaatar (2008). "Sublimation from thin snow cover at the edge of the Eurasian cryosphere in Mongolia." Hydrological Processes 22(18): 3564-3575.

Zhang, Y., O. Tetsuo and S. Kazuyoshi (2005). "Seasonal and inter-annual variation of snow cover surface sublimation in sourthern Siberia and north-eastern Mongolia." Nippon Kisho Gakkai Taikai Koen Yokoshu(87): 350. 
The vita has been removed from the reformatted version of this document. 